\title{
BIOESTRATINOMIA DE CONCENTRAÇÕES FOSSILIIFERAS DA ASSEMBLÉIA DE PINZONELLA NEOTROPICA (REED), FORMAÇÃO CORUMBATAI (PERMIANO), TAMBAÚ, SP
}

\author{
Fernanda de Freitas Torello
}

Orientador: Prof. Dr. Antonio Carlos Rocha-Campos

DISSERTAÇÃO DE MESTRADO

Programa de Pós-Graduação em Geologia Sedimentar 
UNIVERSIDADE DE SÃO PAULO

INSTITUTO DE GEOCIENNCIAS

\section{BIOESTRATINOMIA DE CONCENTRAÇÕES FOSSILÍFERAS DA ASSEMBLÉIA DE PINZONELLA NEOTROPICA (REED), FORMAÇÃO CORUMBATAÍ (PERMIANO), TAMBAÚ, SP}

FERNANDA DE FREITAS TORELLO

Orientador: Prof. Dr. Antonio Carlos Rocha-Campos

DISSERTAÇÃO DE MESTRADO

COMISSÃO JULGADORA

Nome

Presidente: Prof. Dr. Antonio Carlos Rocha-Campos

Examinadores: Prof. Dr. Michael Holz

Prof. Dr. Paulo Roberto dos Santos

SÃO PAULO

1999
Assinatura

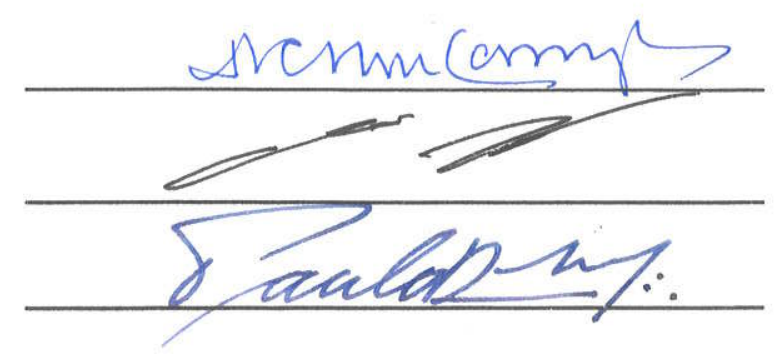




\section{UNIVERSIDADE DE SÃO PAULO INSTITUTO DE GEOCIÊNCIAS}

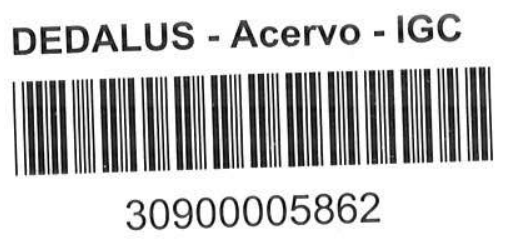

\section{BIOESTRATINOMIA DE CONCENTRAÇÕES FOSSILÍFERAS DA ASSEMBLÉIA DE PINZONELLA NEOTROPICA (REED), FORMAÇÃO CORUMBATAÍ (PERMIANO), NA REGIÃO DE TAMBAÚ, SP}

Fernanda de Freitas Torello

Orientador: Prof. Dr. Antonio Carlos Rocha-Campos

\section{DISSERTAÇÃO DE MESTRADO}

Programa de Pós Graduação em Geologia Sedimentar

São Paulo

1999 
Ao meu avô José Torello

Bernet (in memoriam), com carinho 
ÍNDICE GERAL

RESUMO

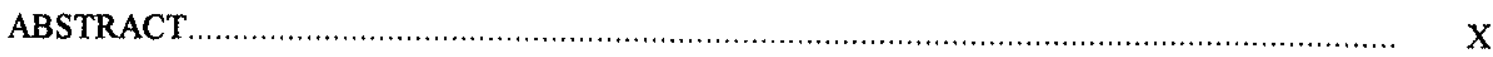

AGRADECIMENTOS

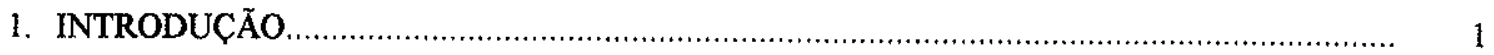

2. OBJETIVOS

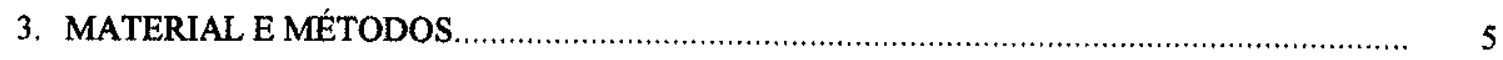

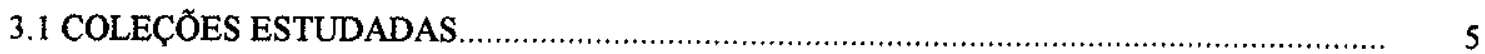

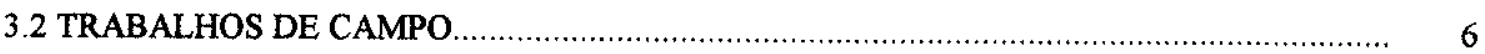

3.3 TRABALHOS DE LABORATÓRIO.

3.4 BANCO DE DADOS BIBLIOGRÁFICO

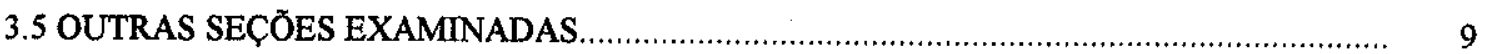

3.6 TERMINOLOGIA EMPREGADA

4. AFLORAMENTOS FOSSILÍFEROS ESTUDADOS ……..................................................... 12

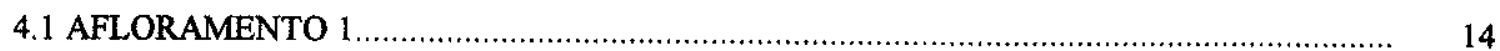

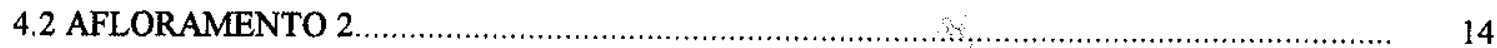

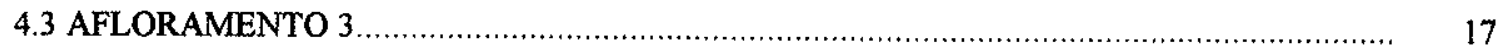

5. TAFONOMIA DAS CONCENTRAÇÕES FOSSILÍFERAS DO GRUPO PASSA DOIS (PERMIANO SUPERIOR): CONHECIMENTO ATUAL, COM ÊNFASE NAS CONCENTRAÇÕES DE PELECÍPODES ......................................................................... 19

5.1 PRIMEIRA FASE: OS TRABALHOS DESCRITIVOS …................................................... 19

5.2 SEGUNDA FASE: PROCESSOS E PRODUTOS .............................................................. 21

5.3 A ELABORAÇÃO DE MODELOS DE TAFOFACIES …................................................... 22

5.4 MISTURA TEMPORAL E RETROALIMENTAÇÃO TAFONÔMICA …............................ 25

6. CRITÉRIOS PARA CLASSIFICAÇÃO DE CONCENTRAÇÕES FOSSILIFFERAS MARINHAS.. 


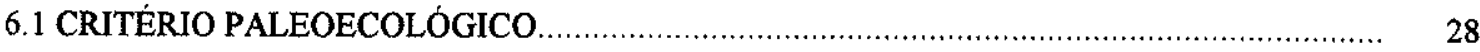

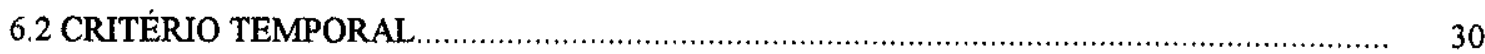

6.3 HISTÓRIA DE ACUMULAÇÃO

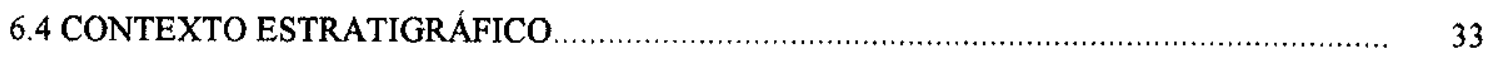

6.5 GEOMETRIA

6.6 CRITÉRIO GENÉTICO.

7. GÊNESE E CLASSIFICAÇÃO DAS CONCENTRAÇÕES FOSSILÍFERAS.DA REGIÃO DE

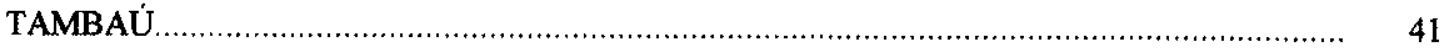

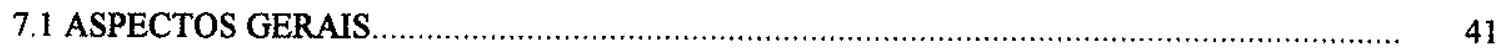

7.2 CONCENTRAÇÃO A E B

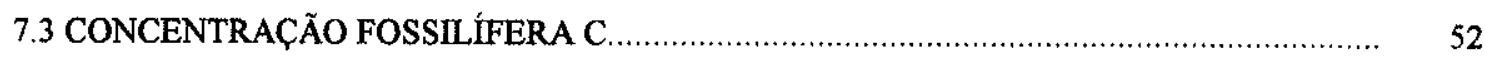

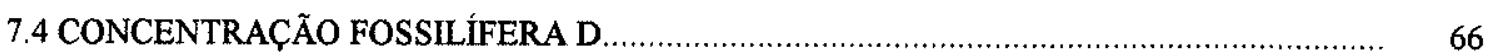

8. MODELO DE TAFOFACIES PARA O GRUPO PASSA DOIS (EXCLUSIVE FORMACÃO

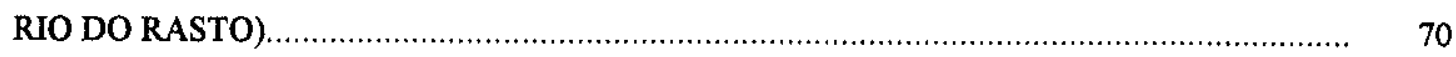

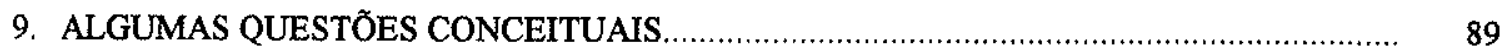

9.1 A MISTURA TEMPORAL VERSUS VARIAÇÃO MORFOLÓGICA INTRAESPECÍFICA

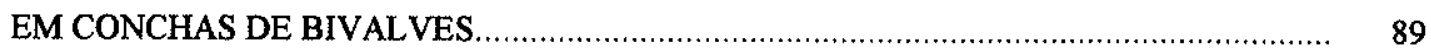

9.2 RETROALIMENTAÇÃO TAFONÔMICA E MISTURA TEMPORAL EM CONCENTRAÇÕES FOSSILÍFERAS GERADAS POR TEMPESTADE ....................... 96

10. CONCLUSÕES

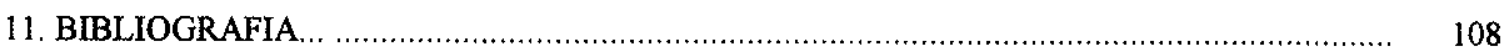




\section{ÍNDICE DE FIGURAS}

Figura 1. Localização dos afloramentos fossiliferos da Formação Corumbataí, na região de Tambaú, São Paulo.

Figura 2. Diferentes graus de empacotamento dos bioclastos em matriz siliciclástica (Simões, 1998)

Figura 3. Seções colunares dos afloramentos estudados na região de Tambaú, SP e suas possiveis correlações. Da esquerda para direita afloramentos 2,1 e 3

Figura 4. Afloramento 1: gretas de contração em siltito fino

Figura 5. Afloramento 1: marcas onduladas em siltito fino.

Figura 6. Afloramento 1: níveis fossilíferos A (inferior) e B (superior) (setas).

Figura 7. Afloramento 2: Detalhe da concentração $C$. Observe o alto grau de imtemperismo do arenito fino/siltito. 16

Figura 8. Afloramento 3: Base da seção medida formada de siltito e arenito intercalado 18

Figura 9. Afloramento 3: Gretas de contração centimétricas em arenito fino 18

Figura 10. Distribuição dos diferentes tipos de concentrações fossiliferas no ambiente marinho ao longo de um gradiente de águas rasas/profundas, onde 1 corresponde a concentração selecionada. Segundo Fürsich e Oschmann (1993). 
Figura 11. Afloramento 1: Arenito fino com moldes de bivalves dispostos paralelamente à estratificação (Concentração $\mathrm{A}$ )

Figura 12. Afloramento 1: Bivalve com a convexidade voltada para baixo (molde) em arenito fino; notar linhas de crescimento bem marcadas (vista em planta; concentração A).

Figura 13. Afloramento 1: molde interno de Pinzonella neotropica com as duas valvas articuladas abertas em matriz síltica. Vista em planta (concentração B) .46

Figura 14. Afloramento 1: distribuição de classes de tamanho de Pinzonella neotropica (A) concentração fossilífera $A$; (B) Concentração fossilífera $B$

Figura 15. Distribuição das classes de tamanho de Cowperesia anceps nas concentrações fossiliferas A e B. Explicação: A= concentração fossilífera A, B= concentração fossilífera B.

Figura 16. Afloramento 2: Concentração fossilifera C. Notar aumento do grau de empacotamento dos bioclastos em direção ao topo .55

Figura 17. Afloramento 2: Concentração fossilifera $\mathrm{C}$ : presença de conchas aninhadas (em corte) .55

Figura 18. A) Freqüência de ocorrência de seleção e de cobertura lamosa de acordo com a profundidade. B) Padrão geral de variação da espessura da cobertura lamosa de acordo com a profundidade. Explicação: NBON: base das ondas normais; NBOT Méd.: base média das ondas de tempestade; NBOT Máx.: base máxima das ondas de tempestade (modificado de Miller et al., 1988). .58

Figura 19. Freqüência esperada de preservação de depósitos de tempestade de acordo com a profundidade. Explicação: NMP: nível principal do mar; NBON: base das ondas 
normais; NBOT: base das ondas de tempestade (modificado de Miller et al., 1988)

Figura 20. Modelo simplificado de evento de tempestade mostrando a posição batimétrica relativa de concentrações fossiliferas selecionadas e camadas de argila produzidas por um evento único de tempestade. Explicação: NMP: nível principal do mar; NBON: base das ondas normais; NBOT: base das ondas de tempestade. Escala verticalmente exagerada (modificado de Miller et al., 1988). 60

Fig. 21. Importância relativa dos processos que atuam na plataforma. Notar a intensidade dos processos de retrabalhamento em ambiente proximal (modificado de Norris, 1986)

Figura 22. Relações entre o processo de colonização do substrato e as interações entre organismos vivos e restos esqueléticas já depositados no fundo, as taxas de sedimentação e os processos sedimentares e seus respectivos produtos (modificado de Kidwell, 1991) 65

Figura 23. Distribuição das classes de tamanho de Pinzonella illusa e Cowperesia anceps na concentração fossilifera $\mathrm{C}$. Explicação: $\mathrm{A}=$ Pinzonella neotropica e $\mathrm{B}=$ Cowperesia anceps. 67

Figura 24. Modelo de facies tafonômicas para o Grupo Passa Dois (formações Serra Alta, Terezina e Corumbataí) ao longo de um perfil de águas rasas profundas, segundo Simões e Torello (em preparação). Veja explicação no texto .74

Figura 25. Proporção dos três morfotipos (A, B, C) observada na concentração fossilífera de Anhembi, SP 92

Figura 26. Classes de tamanho dos três morfotipos $(A, B, C)$ da concentração fossilífera de Anhembi 92 
Figura 27. Proporção dos 3 morfotipos (A, B, C) observada na concentração fossilifera A de Tambaú. .93

Figura 28. Classes de tamanho dos três morfotipos $(A, B, C)$ da concentração fossilífera A de Tambaú 93

Figura 29. Freqüência dos três morfotipos (A, B e C) nas quatro concentrações fossiliferas estudadas e a relação com a mistura temporal .95

Figura 30. Processos de retroalimentação tafonômica decorrente de sucessivos eventos concentradores de material bioclástico em ambiente de planície de maré (litoral de Jeram, Malásia). Modificado de Seilacher (1985) 100

Figura 31. Tipos de concentrações fossilíferas propostas por Kidwell (1986b), de acordo com a natureza dos contatos superior e inferior. (modificado de Kidwell, 1986b). 102

Figura 32. Diferença do grau de empacotamento nos quatro tipos de concentrações fossilíferas propostas por Kidwell (1986b) e suas conseqüências no grau de mistura temporal e presença de táxons adaptados a substrato mole e duro (modificado de Kidwell, 1986b). 103

Figura 33. Aspecto geral de concha de Naiadopsis lamellosus, elemento da semi-infauna bissada, presente no topo da concentração fossilifera $C$, preservada em posição de vida. 


\section{ÍNDICE DE TABELAS}

Tabela 1: Comparação entre tafofácies propostas por Rohn Penatti (1993) e Simões (1996a) para o Grupo Passa Dois, Bacia do Paraná

Tabela 2: Classificações de concentrações fossiliferas de acordo com o critério paleoecológico. .29

Tabela 3: Classificação de concentrações fossiliferas marinhas levando-se em conta o critério temporal.

Tabela 4: Classificações de concentrạ̧ões fossilíferas marinhas de acordo com a história de acumulação. 32

Tabela 5: Classificação de Klidwell (1985) com base no estratigráfico. .34

Tabela 6: Classificações de concentrações fossiliferas marimhas com base na geometria da concentração esquelética. 35

Tabela 7: Classificações propostas segundo critério genético de concentrações fossilíferas marinhas. 37

Tabela 8: Comparação entre as caracteristicas das concentrações fossiliferas 1 e $2 \ldots . . .44$

Tabeia 9: Comparação entre as tafofacies propostas por autores prévios (Rohn e Penatti, 1993 e Simões, 1996a) e no presente trabalho. 


\section{RESUMO}

Quatro novas ocorrências de concentrações fossiliferas de bivalves da Formação Corumbataí (Grupo Passa Dois, Neopermiano), na região de Tambaú, NE do Estado de São Paulo, são descritas e interpretadas bioestratinomicamente na presente dissertação. As concentrações (A-D) contém bivalves característicos da assembléia de Pinzonella neotropica, incluindo: Pinzonella neotropica, Cowperesia anceps, Jacquesia brasiliensis, Holdhausiella elongata, Naiadopsis lamellosus e Terraiopsis aequilateralis, correspondente à parte superior da Formação Corumbataí.

A localização das concentrações na estratigrafia local envolveu o levantamento de três seções estratigráficas de detalhe (1-3), acompanhado da análise sumária de facies sedimentares. A análise bioestratinômica baseou-se em observações e medidas de campo, no estudo de blocos orientados, coletados no campo e analisados em laboratório, e no exame de coleções adicionais de bivalves e de amostras de concentrações pertencentes a várias instituições brasileiras. Este estudo e o exame da maior parte da bibliografia tafonômica disponível permitiu a elaboração de um banco de dados tafonômicos, de grande valia para a análise realizada. A dissertação inclui ainda revisões críticas da evolução histórica dos estudos tafonômicos e das classificações das associações fossiliferas. As concentrações A e B situam-se na seção 1 e as C e D, respectivamente, nas seções 2 e 3 . De modo geral, as facies presentes indicam que as rochas da Formação Corumbataí, depositaram-se em ambientes marinhos rasos, dominados por tempestades e esporadicamente expostos subaereamente. A variação lateral de facies e ausência de camadas guia tornou dificil a correlação entre as seções levantadas e das próprias concentrações. As concentrações fossilíferas parecem constituir ocorrências estratigraficamente distintas.

Uma característica geral das concentrações analisadas consiste na inclusão de bivalves de diferentes modos de vida e em variado estado de preservação. Estes elementos sugerem mistura temporal dos bioclastos.

As concentrações A e B assemelham-se bioestratigraficamente e são formadas por bioclastos de Pinzonella neotropica e Cowperesia anceps dispersos em matriz arenosa/siltica. A maioria das conchas está desarticulada, porém não fragmentada. 
Conchas articuladas e abertas também ocorrem. As feições sugerem que estas concentrações fossilíferas foram depositadas através de eventos de sedimentação episódica, provavelmente tempestades, representando tempestitos distais.

Conchas de Pinzonella neotropica, Jacquesia brasiliensis, Holdhausiella elongata e Naiadopsis lamellosus estão dispersas ou densamente empacotadas na matriz arenosa/síltica, na concentração C. Conchas aninhadas e empilhadas são encontradas. A maioria dos fósseis dispõe-se caoticamente na matriz e apresenta-se desarticulada, exceto Naiadopsis lamellosus, às vezes encontrada em posição de vida, no topo da concentração. Nota-se mistura de conchas em diversos estados de preservação, porém não há sinais de bioerosão ou incrustação. A concentração foi provavelmente gerada por eventos de tempestade e preservada, incluindo bivalves em posição de vida, pela mudança no nível da base das ondas de tempestade. A presença de Naiadopsis lamellosus, um bivalve da semi-infauna bissada, preservado in situ sobre bioclastos previamente depositados sugere retroalimentação tafonômica na concentração $\mathrm{C}$. Representa, pois, um tempestito distal, com alto grau de mistura temporal, como demonstra a presença de conchas articuladas fechadas (in situ) e desarticuladas da mesma espécie.

Finalmente, a concentração D exibe somente valvas desarticuladas, a maioria não fragmentada, de Pinzonella neotropica, Cowperesia anceps e Terraiopsis aequilateralis que ocorrem em matriz arenosa. Representa ela, também, uma concentração gerada por tempestade, configurando um tempestito proximal.

O presente estudo e o exame de outras concentrações fossilíferas do Grupo Passa Dois revelou uma ampla variação morfológica de Pinzonella neotropica, envolvendo três morfotipos (concha alongada, intermediária e arredondada). Estes estão presentes conjuntamente, apenas nas concentrações fossilíferas com alto grau de mistura temporal (e.g., coquinas), sugerindo que esta pode ser responsável pela diversidade morfológica da espécie verificada nas concentrações.

O presente estudo permitiu complementar o modelo de tafofacies do Grupo Passa Dois (formações Serra Alta, Terezina e Corumbataí). Cinco tafofacies foram identificadas e caracterizadas, refletindo a variação de condições bioestratinômicas, ao longo de um perfil batimétrico de águas rasas a profundas. 


\begin{abstract}
The description and biostratinomic interpretation of four new occurrences of fossil bivalve concentrations in the upper Corumbatai Formation near Tambaú region, northeastern São Paulo, Brazil, are here presented. Bivalves typical of the Pinzonella neotropica assemblage, that is, Pinzonella neotropica, Cowperesia anceps, Jacquesia brasiliensis, Holdhausiella elongata, Naiadopsis lamellosus e Terraiopsis aequilateralis, are found in these concentrations. The bioestratinomic analysis was based on field observations and measurements, study of oriented blocks, and examination of additional bivalve collections and samples of concentrations belonging to several Brazilian institutions. A taphonomic data bank was developed using information derived from this study and the iterature. Additionally, historical evolution of taphonomic studies and classification of fossil associations are critically reviewed.

In order to place these concentrations within the local stratigraphic context, three stratigraphic sections were described in detail and briefly analyzed as to their sedimentary facies. These facies indicate that the Corumbatai Formation rocks were deposited under shallow water, in a storm-dominated setting, and rarely exposed subaerialy. The Lateral facies variations and the lack of marker beds made correlation among the described sections and concentrations difficult. These concentrations seem to represent distinct biostratigraphical occurrences.
\end{abstract}

Bivalves presenting different life habits and preservational states are characteristic of all four concentrations, which suggest that they are time-averaged accumulations.

Concentrations $\mathrm{A}$ and $\mathrm{B}$ are biostratinomically similar, being composed by Pinzonella neotropica and Cowperesia anceps in a sandy matrix. Disarticulated, but unfragmented shells are dominant, and closed and butterflied shells are present. These features suggest that these shell beds were probably deposited below storm-wave base (distal tempestite).

In concentration C, Pinzonella neotropica, Jacquesia brasiliensis, Holdhausiella elongata and Naiadopsis lamellosus shells are loosely or densely packed in a sandy matrix, with some nesting and stacking. Most of the fossils are found disarticulated and chaotically distributed in the matrix, but some specimens of Naiadopsis lamellosus are 
observed in life positions at at the top the shell bed. It is clearly noticeable the mixing of shells. Different preservational states, are clearly evident among the shells, but signs of bioerosion and encrustation are lacking. Probably, the concentration was generated by storm events, later occupied by the semi-infaunal, byssally attached bivalve Naiadopsis lamellosus, in a clear case of taphonomic feedback. Changes in the storm-wave base level led to burial by clays. These concentrations can be interpreted as distal tempestites with high time averaging, as demonstrated by closed articulated (in situ) and disarticulated shells of the same species.

In concentration $\mathrm{D}$, only disarticulated, unfragmented valves of Pinzonella neotropica, Cowperesia anceps and Terraiopsis lamellosus, occurring in a sandy matrix are found, which probably represents a storm-generated, proximal tempestite.

As revealed by the present study and by additional examination of other Passa Dois Group fossil concentrations, Pinzonella neotropica presents a wide variation in shell morphology, with three distinct morphotypes (elongate, intermediate and rounded), found together only in high time-averaged fossil concentrations (e.g., coquina), suggesting that time-averaging may be the very cause of morphological diversity in this concentration.

This study supplements the present taphofacies model for the Passa Dois Group (Serra Alta, Terezina and Corumbataí formations) and recognize five taphofacies indicative of varied biostratinomic conditions along an onshore-offshore transect. 


\section{AGRADECIMENTOS}

Gostaria de agradecer a todos que direta ou indiretamente colaboraram na elaboração desta dissertação, em especial:

Ao Prof. Dr. Antonio Carlos Rocha-Campos pela orientação e atenção dispensada;

Ao Prof. Dr. Marcello Guimarães Simões (IBB-UNESP Botucatu), pela sugestão do tema, revisões, acompanhamento nos trabalhos de campo e laboratório, apoio, incentivo e sobretudo amizade;

Ao Luiz Henrique Cruz de Mello, pelo auxílio em todas as etapas de elaboração desta dissertação, pelo incentivo, paciência, companheirismo e sobretudo pelo seu grande amor;

Ao amigo Renato Pirani Ghilardi pela amizade, auxílio durante os trabalhos de campo e ajuda com bibliografias;

Ao Dr. Michael Kowalewski (Virginia Tech University, USA) pelos conhecimentos transmitidos durante sua vinda ao Brasil;

Ao Prof. Dr. Thomas R. Fairchild pela revisão do Abstract;

Ao Departamento de Zoologia do Instituto de Biociências UNESP - Botucatu pelas facilidades oferecidas para a realização da presente dissertação, em especial aos docentes e funcionários Maria Aparecida Nunes de Oliveira, José Mario Pizani, Ana Maria Fernandes, Juliana Ramos e Flávio da Silva;

Aos docentes e funcionários do Departamento de Paleontologia e Estratigrafia do IG/USP;

Aos funcionários do Instituto de Geociências, em especial à Ana Paula Cabral Pentagna (Seção de Pós Graduação) e Brenda Maria Mascarenhas (Biblioteca);

A FAPESP e ao CNPq pelo apoio financeiro através dos projetos FAPESP93/2747-0, 96/101008-6, 94/5021-3, 96/9708-9 e CNPq e financiamento dos trabalhos de campo (FAPESP 96/9708-9). Projetos em nome do Prof. Dr. Marcello Guimarães Simões. 
A Sra. Adelaide Ferreira Simões pela estadia em Mococa durante os trabalhos de campo;

Aos meus pais Juan Torello Forn e Maria Beatriz de Freitas Torello, meus irmãos Karina e Mauro e minha família pelo constante incentivo e apoio e principalmente por sempre acreditarem em mim.

À Lucia Zamith, Magda Pearson, Juliana de Moraes Leme, Sabrina Coelho Rodrigues, Juliana Nunes e Ligia Barrozo Simões pela amizade. 


\section{INTRODUÇÃO}

Concentrações de material bioclástico constituídos por restos de conchas e ossos são feições comuns e conspícuas no registro geológico fanerozóico. A presença de concentrações fossiliferas (Kidwell e Bosence, 1991), formadas por acúmulo de conchas de bivalves ("shell beds", sensu Kidwell e Brenchley, 1996), cujas espécies são atribuídas às chamadas assembléias de Anhembia froesi, Pinzonella illusa e Pinzonella neotropica (Mendes, 1952; Runnegar e Newell, 1971; Maranhão, 1986) é uma das características mais notáveis da Formação Corumbataí (Neopermiano). De maneira geral, esses bivalves ocorrem dispersos na matriz, ou mais comumente concentrados na forma de coquinas ou arenitos bioclásticos, em diversas regiões do Estado de São Paulo, tais como: Rio Claro (Mendes, 1952; Runnegar e Newell, 1971; Simões e Fittipaldi, 1987, 1992; Simões et al., 1994, 1996a, 1998c; Torello e Simões, 1994; Simões, 1996a, 1998; Simões e Kowalewski, 1998a, b); Tambaú-Santa Cruz das Palmeiras (Dalponte e Gonçalves, 1979; Maranhão, 1995; Torello e Simões, 1996); rodovia Castello Branco (Maranhão, 1995; Simões e Anelli, 1995; Maranhão e Petri, 1997; Torello et al., 1997; Mello et al., 1998; Simões et al., 1998c, em preparação); Leme (Simões et al., em preparação) e Angatuba (Mendes, 1962; Runnegar e Newell, 1971).

Para as concentrações fossilíferas da região de Rio Claro, estudos envolvendo conceitos evolutivos, paleoecológicos e tafonômicos modernos já estão disponiveis (Simões e Fittipaldi, 1987, 1992; Simões et al., 1998c). A maior parte dos estudos está fundamentada em material proveniente de afloramentos da antiga estrada que liga Ajapi ao distrito de Ferraz (Mendes, 1952; Torello e Simões, 1994; Simões, 1998; Simões e Kowalewski, 1998a, b), da estrada que conduz à Fazenda Santana de Urucaia (= Rua 6) (Simões et $a l$, 1994; Simões, 1996a) e da seção aflorante junto ao Horto Florestal (=Camaquã; Mendes, 1952; Simões et al., 1996a).

Estudos tafonômicos mais recentes (Torello e Simões, 1994; Simões et al., 1994, 1996a; Simões, 1998; Simões e Kowalewski, 1998a, b) demonstraram que as coquinas e os arenitos coquinóides da Formação Corumbataí de Rio Claro correspondem a tempestitos proximais gerados respectivamente por fluxos de tempestade e ondas de tempestade (sensu Fürsich e Oschmann, 1986, 1993). Essas concentrações fossiliferas 
possuem história tafonômica e sedimentar extremamente complexa (Simões et al., 1996a, b; Simões, 1998; Simões e Kowalewski, 1998a, b), com alto grau de mistura temporal ("time-averaging").

Estudos tratando de concentrações fossiliferas contendo bivalves, da região nordeste do Estado de São Paulo, incluindo a região de Tambaú, são, entretanto, ainda escassos (Dalponte e Gonçalves, 1979; Maranhão, 1995). Pesquisas já realizadas (Dalponte e Gonçalves, 1979) tratam, principalmente, da composição taxonômica das assembléias, as quais, segundo informações prévias da literatura, estão preservadas, semelhantemente às da região de Rio Claro, sob a forma de bioclastos dispersos ou densamente empacotados na matriz. Apesar de Maranhão (1995) ter abordado alguns aspectos bioestratinômicos de concentrações fossiliferas dessa região, inexistem estudos tafonômicos mais aprofundados, adequados à interpretação dos processos geradores dessas concentrações.

As feições tafonômicas de concentrações fossiliferas podem fornecer informações importantes sobre o caráter parautóctone ou alóctone de concentrações fossiliferas. Através da análise dessas feições, podem ser reconhecidas concentrações geradas rapidamente, durante instabilidade ambiental (e.g., tempestades, eventos de mortalidade em massa) ou sob a forma de acúmulos condensados que abrangem um intervalo de tempo maior. Na maior parte dos casos, pode-se concluir também se, durante a gênese, houve mistura de restos esqueléticos de populações ou comunidades não contemporâneas ("time-averaging", Fürsich e Aberhan, 1990). As concentrações fossiliferas podem, também, ser classificadas geneticamente (Fürsich e Oschmann, 1993), através das assinaturas tafonômicas e qualidade de preservação dos elementos esqueléticos, esclarecendo, assim, os processos e ambientes envolvidos na sua formação.

Tendo em vista os elementos discutidos acima, o presente estudo foi empreendido visando interpretar a gênese e a classificação das concentrações fossiliferas de Tambaú, determinar o caráter parautóctone ou alóctone dessas concentrações, assim como os processos e condições ambientais relacionados à sua gênese. É importante destacar que tais aspectos foram, de modo gerai, já debatidos na literatura (e.g., Simões, 1998; Simões e Kowalewski, 1998a; Simões et al., submetido). Porém, conforme observado por Simões et al. (submetido) o soterramento final de uma concentração 
esquelética pode-se dar a qualquer momento e, em qualquer estágio de desenvolvimento de uma dada população. Deste modo, mesmo que geradas em um mesmo ambiente, por processos similares e durante o mesmo intervalo estratigráfico, concentrações fossilíferas de diferentes regiões de uma bacia sedimentar não serão necessariamente idênticas. Com efeito, a ampla investigação de concentrações esqueléticas ao longo de um trato de facies semelhantes pode fornecer subsídios para a verificação de hipóteses tafonômicas que possuem profundas implicações paleoecológicas, porque poderão estar aí registradas acumulações esqueléticas geneticamente correlativas, porém preservadas em diferentes estágios de desenvolvimento.

É nesse contexto mais teórico e amplo que a presente análise tafonômica inserese. 


\section{OBJETIVOS}

Tendo em vista os comentários apresentados anteriormente, a presente dissertação foi desenvolvida com os seguintes objetivos:

\section{Objetivos principais:}

a) descrever, do ponto de vista tafonômico, as concentrações fossilíferas da parte superior da Formação Corumbataí (Neopermiano), em Tambaú, SP;

b) interpretar a gênese das concentrações fossiliferas analisadas, com base nas assinaturas tafonômicas identificadas;

c) discutir aspectos relacionados à paleoautoecologia de espécies presentes nas concentrações fossilíferas estudadas, procurando confrontar os aspectos morfofuncionais com os aspectos tafonômicos observados.

\section{Objetivos secundários:}

a) confrontar os dados obtidos com os disponiveis na ampla literatura sobre tafonomia das concentrações fossiliferas do Grupo Passa Dois, procurando a partir daí:

- testar a hipótese de que o processo de mistura temporal e espacial de restos esqueléticos pode contribuir para o aumento artificial da diversidade morfológica de um dado táxon, com óbvias implicações para a sistemática paleontológica; - examinar a questão da retroalimentação tafonômica, procurando identificar feições tafonômicas que permitam o seu reconhecimento e a identificação de possiveis padrões temporais envolvidos nesse processo;

- ampliar e complementar o modelo de facies tafonômicas da Formação Corumbataí proposto por Simões (1996a). 


\section{MATERIAIS E MÉTODOS}

\subsection{COLEÇÕES ESTUDADAS}

O material básico utilizado no presente estudo constou de cerca de 650 amostras coletadas nos afloramentos examinados. Após sua preparação e estudo, foram elas incorporadas à coleção científica do Laboratório de Paleozoologia Evolutiva do Departamento de Zoologia (Instituto de Biociências, UNESP, campus de Botucatu, SP), sob os números DZP 1105-1111, 1246-1803, 1916-1928 e 2480-2564.

Foram examinadas adicionalmente:

- cerca de 260 amostras pertencentes à coleção científica do Laboratório de Paleozoologia (Litoteca do Departamento de Zoologia, UNESP, campus de Botucatu), provenientes das formações Corumbataí, Serra Alta e Terezina do Estado de São Paulo (DZP-LT 01-84/121-193/213-256/371-431).

-cerca de 70 amostras apresentando feições tafonômicas, provenientes de sedimentos da parte superior do Grupo Passa Dois dos estados de Paraná, Santa Catarina e Rio Grande do Sul pertencentes ao Departamento de Geologia Sedimentar, Instituto de Geociências e Ciências Exatas da UNESP- Rio Claro, Rio Claro, SP e Museu de Paleontologia da Universidade do Vale do Rio dos Sinos (UNISINOS), São Leopoldo, RS.

- cerca de 300 espécimes provenientes da Formação Corumbataí, pertencentes à Coleção de Pesquisa do Departamento de Paleontologia e Estratigrafia, Instituto de Geociências, USP.

O amplo material adicional examinado permitiu obter uma visão geral do espectro de tipos de acumulações conchíferas das formações Corumbataí, Serra Alta e Terezina formados, predominantemente, em ambientes marinhos rasos, dominados por eventos de alta energia. 


\subsection{TRABALHOS DE CAMPO}

Os trabalhos de campo incluíram a procura de afloramentos fossiliferos, levantamento de seções estratigráficas para localização das concentrações conchiferas e coleta de amostras para estudos de laboratório.

A primeira etapa de campo envolveu a tentativa de localização dos afloramentos descritos por Dalponte e Gonçalves (1979), especialmente as ocorrências fossilíferas junto à antiga estrada secundária que liga Tambaú a Santa Rosa do Viterbo, mais ao norte da cidade de Tambaú. Porém, após diversas tentativas, em razão da imprecisão das descrições de Dalponte e Gonçalves (1979), estes afloramentos não foram encontrados. Maranhão (1995), por sua vez, examinou, principalmente, as acumulações fossilíferas que ocorrem nos afloramentos ao longo da Rodovia Padre Donizete (SP-332).

Após o reconhecimento realizado e com base em informações estratigráficas prévias (Soares et al., 1973; IPT, 1981) e paleontológicas levantadas, foram selecionados para estudo três afloramentos contendo concentrações fossilíferas, denominados 1, 2 e 3 (Fig. 1), situados ao norte de Tambaú. Nesses locais, seções estratigráficas foram levantadas, adiante descritas.

A amostragem dos níveis fossilíferos variou de acordo com as condições dos afloramentos, mas consistiu, no geral, da retirada de blocos orientados, com cerca de 20 $\mathrm{cm}^{2}$ (Simões e Kowalewski, 1998a).

No caso do afloramento 1, algumas medidas e observações tafonômicas foram tomadas no campo, tendo em vista o alto grau de intemperismo do arenito fossilifero. Desta maneira, quadrantes de $30 \mathrm{~cm} \times 30 \mathrm{~cm}$ foram demarcados aleatoriamente em três pontos sorteados do pavimento para a tomada de informações, tais como orientação das conchas, proporção de valvas direitas e esquerdas, e proporção de valvas articuladas fechadas, articuladas abertas ("butterflied") e desarticuladas. As conchas foram, a seguir, moldadas em massa para modelagem e reproduzidas em gesso. A partir dos moldes de gesso, foram produzidas réplicas das conchas em látex para posteriormente serem recobertas com magnésio metálico, para a obtenção de fotografias. 

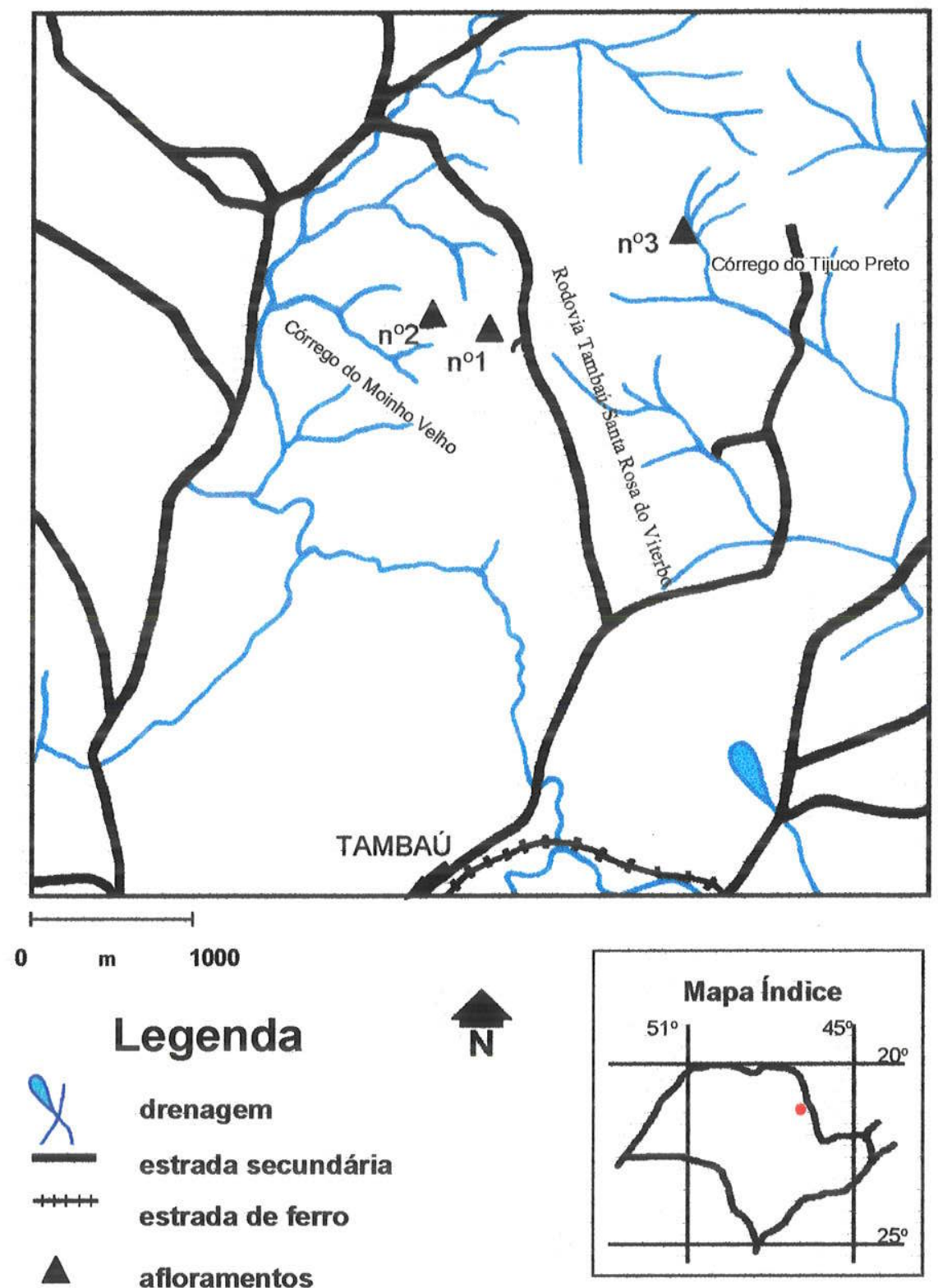

Figura 1. Localização dos afloramentos fossilíferos da Formação Corumbataí, na região de Tambaú, São Paulo. 
Além dos três afloramentos principais analisados, outras ocorrências de concentrações fossilíferas das formações Corumbataí e outras do Grupo Passa Dois foram estudadas, com vistas a elaborar um modelo geral de facies tafonômicas para o Neopermiano da Bacia do Paraná.

\subsection{TRABALHOS DE LABORATÓRIO}

A preparação das amostras coletadas, em laboratório, seguiu a técnica proposta por Simões (1988) e Simões e Fittipaldi $(1988,1992)$.

Quando possível, os blocos foram seccionados para possibilitar a descrição de feições tafonômicas importantes (e.g., grau de empacotamento, disposição dos bioclastos na matriz). Os blocos foram também partidos horizontalmente, seguindo os planos de acamamento, presentes internamente em alguns deles (e.g., concentração fossilífera $\mathrm{A}$ ).

\subsection{BANCO DE DADOS BIBLIOGRÁFICO}

Uma ampla compilação de dados tafonômicos publicados na literatura, a partir da década de 1980, foi realizada com o intuito de fundamentar a presente análise. Aproximadamente $80 \%$ das referências disponíveis foram examinadas particularmente quanto aos seguintes aspectos: a) assinaturas tafonômicas das concentrações fossilíferas; b) geometria e contatos estratigráficos; c) espessura e grau de empacotamento e, d) processos e ambiente deposicional.

$\mathrm{O}$ banco de dados foi constantemente atualizado durante o decorrer da pesquisa e encontra-se em fase de informatização. 


\subsection{OUTRAS SEÇÕES EXAMINADAS}

Em adição aos afloramentos estudados, foram também examinadas outras seções do Grupo Passa Dois, assim distribuídas:

a)Porção centro sul do estado de São Paulo, região de Porangaba-Bofete

- Afloramento fossilífero do km 160,650 da Rodovia Castello Branco (SP-280), Formação Serra Alta, incluindo sucessão de siltito, siltito argiloso e folhelho síltico, cinza escuros, mais raramente cinza avermelhado, com intercalações centimétricas de arenito fino, cinza claro, apresentando conchas de bivalves (Mello et al., 1998; Simões et al., em preparação).

- Afloramento fossilífero do km 161,5 da Rodovia Castello Branco, Formação Serra Alta, incluindo siltito predominantemente cinza escuro, maciço, apresentando fósseis de bivalves (Simões e Rohn, 1996; Mello et al., 1998; Simões et al., em preparação).

- Afloramento fossilifero do $\mathrm{km} \mathrm{164,} \mathrm{Formação} \mathrm{Terezina,} \mathrm{apresentando}$ intercalações de siltito arroxeado e arenito médio a fino e incluindo bivalves e icnofósseis (Sousa, 1985; Maranhão, 1995; Torello et al., 1997; Simões et al., em preparação).

b)Porção nordeste do estado de São Paulo, região de Rio Claro-Piracicaba

- Afloramento fossilifero localizado na rodovia Fausto Santomauro (SP127) km10,5, Formação Corumbataí, incluindo siltitos arroxeados com finas intercalações de arenito e apresentando fósseis de bivalves (Ghilardi et al., 1997; Ghilardi, 1999; Simões et al., em preparação).

- Afloramento de Camaquã, Rio Claro, SP, Formação Corumbataí, incluindo seqüência de siltito com intercalações de lentes de arenito fino e apresentando fósseis de bivalves (Simões et al., 1996a).

- Afloramento de Ferraz, Rio Claro, SP, Formação Corumbataí, situado a 1,5km da antiga estação ferroviária de Ferraz, incluindo siltito arroxeado com intercalações de arenito e apresentando fósseis de bivalves (Torello e Simões, 1994; Simões, 1996a, 1998; Simões e Kowalewski, 1998a,b). 
- Afloramento da Rua 6, Rio Claro a 200m do entroncamento com a rodovia para Araras, Formação Corumbataí, incluindo seqüência de siltito com intercalações de arenito e apresentando fósseis de bivalves (Simões, 1996a, 1998; Simões et al., 1994)

c)Porção nordeste do Estado de São Paulo, região de Leme

-Afloramento fossilífero de Leme, extração da Cerâmica Maristela $\left(22^{\circ} 09^{\prime} 35^{\prime \prime} \mathrm{S} / 47^{\circ} 23^{\prime} 40^{\prime \prime} \mathrm{W}\right)$, Formação Corumbataí, inclui seqüência de siltito arroxeado apresentando bivalves (Simões et al., em preparação).

\subsection{TERMINOLOGIA EMPREGADA}

A terminologia empregada na descrição das concentrações fossiliferas estudadas segue Brett e Baird (1986), Kidwell et al. (1986), Kidwell e Bosense (1991) e Fürsich e Oschmann $(1986,1993)$. A nomenclatura utilizada na interpretação da paleoecologia dos bivalves é a empregada por Stanley $(1970,1972)$ e Runnegar (1974). A terminologia proposta por Kidwell e Holland (1991) e Kidwell e Brenchley (1996) foi adotada na presente dissertação.

Conforme destaca Kidwell e Holland (1991), os termos utilizados para descrição dos diversos tipos de concentrações fossilíferas marinhas, com base no grau de empacotamento, ainda não possuem uma padronização na literatura. Diversos autores têm utilizado termos distintos para denominar concentração fossilíferas geradas em ambiente marinho.

O termo coquina, por exemplo, não é sedimentologicamente preciso. Segundo Kidwell e Holland (1991), sedimentos bioclásticos com matriz não carbonática tem sido comumente denominados por vários termos não padronizados, como coquina, "bone bed", "shell bed", "shell gravel" e "lumachelle" (na Europa), ou ainda pelo ambíguo adjetivo: fossilífero.

A fim de solucionar esta questão, Kidwell e Holland (1991) propuseram uma padronização da terminologia empregada para depósitos bioclásticos, utilizando feições como empacotamento e seleção por tamanho. Os termos densamente empacotado, 
pobremente empacotado, disperso e ausente, foram utilizados tanto para rochas carbonáticas como terrígenas (Fig. 2). Coquina, neste caso, corresponderia a uma concentração fossilifera densamente empacotada composta por conchas ou outros restos bioclásticos. Grãos esqueléticos menores que $2 \mathrm{~mm}$ são considerados matriz sedimentar. A terminologia proposta por Kidwell e Holland (1991) e Kidwell e Brenchley (1996) foi adotada na presente dissertação.

O termo mistura temporal ("time averaging") é aqui empregado segundo a proposta de Kowalewski (1996), isso é: "the process by which events that happened at different times appear to be synchronous in the geological record"'.

GRAU DE EMPACOTAMENTO

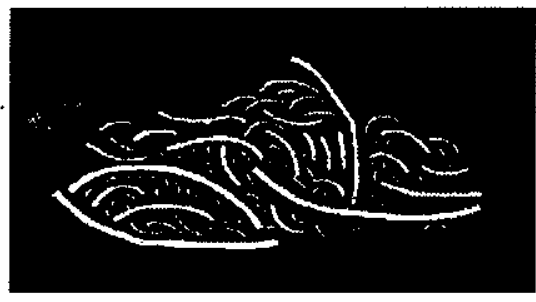

Densamente empacotado suportado por blociactos

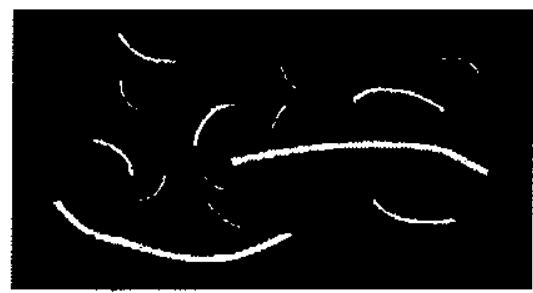

Fracamente empacotado suportado pela matriz

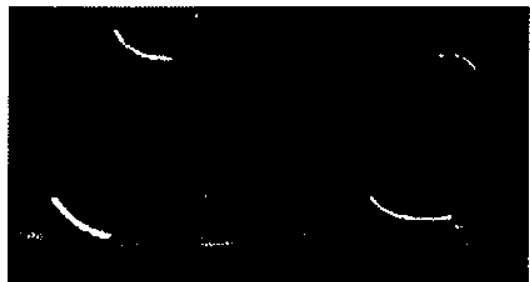

Disperso

suportado pela matriz

Figura 2. Diferentes graus de empacotamento dos bioclastos em matriz siliciclástica (Simões, 1998). 


\section{AFLORAMENTOS FOSSHÍFEROS ESTUDADOS}

As concentrações fossilíferas estudadas são correlacionáveis à Assembléia de Pinzonella neotropica (Reed) da parte superior da Formação Corumbataí, Grupo Passa Dois (Neopermiano).

Rochas dessa unidade, no Estado de São Paulo, exibem um conjunto de estruturas sedimentares interpretadas como indicativas de ambiente de planície de maré (Sousa, 1985; Rohn, 1994), equivalentes à facies III de Sousa (1985). O mesmo tipo de condições ambientais parece ter prevalecido durante a deposição da Formação Corumbataí, na região abrangida pela presente pesquisa.

Quatro concentrações fossiliferas selecionadas para estudo ocorrem nos três afloramentos levantados, da seguinte maneira:

- Afloramento 1: concentrações A e B

- Afloramento 2: concentração C

- Afloramento 3: concentração D

Seções colunares levantadas, representativas da estratigrafia dos afloramentos estudados são apresentados na Figura 3, onde a correlação entre as seções levantadas tornou-se dificil devido a variação lateral de facies e ausência de camadas-guia. 


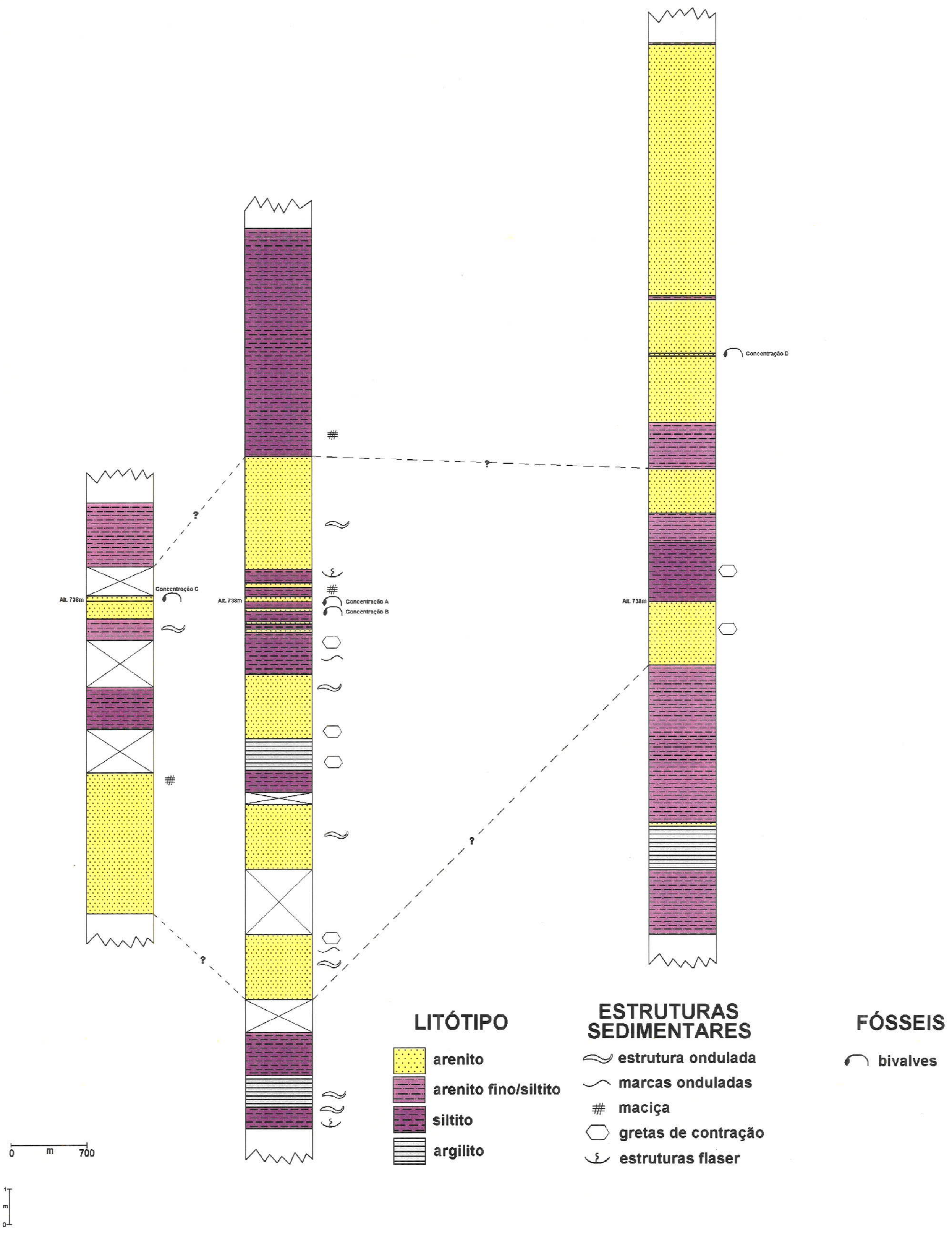

Figura 3. Seções colunares dos afloramentos estudados na região de Tambaú, SP e suas possíveis correlações. Da esquerda para direita afloramentos 2 , 1 e 3. 


\subsection{AFLORAMENTO 1}

Situa-se na estrada secundária que liga Tambaú a Santa Rosa do Viterbo, a cerca de 5,2 km do rio Tambaú, a partir da cidade de mesmo nome. Após 3,2km a partir do rio Tambaú, existe o entroncamento para a Fazenda São Roque, a esquerda do entroncamento e após $2 \mathrm{~km}$ afloram sedimentos da Formação Corumbataí, na margem direita da estrada. Nesta seção são encontradas as concentrações fossilíferas A e B, descritas mais adiante.

A seção medida tem $90,2 \mathrm{~m}$ de espessura, dos quais os primeiros $47,5 \mathrm{~m}$, a partir da base, estão cobertos por vegetação. $O$ pacote é formado por arenito, siltito e argilito. A partir de 47,5m da base, após os sedimentos encobertos, ocorre um pacote com aproximadamente $2 \mathrm{~m}$ de arenito fino/siltito, com gretas de contração (Fig.4) em siltitos esverdeados, que mostram marcas onduladas (Fig.5) e estrutura ondulada ("wavy"). Sobrepondo-se a este ocorre um pacote de siltito e argilito com gretas de contração, os quais são seguidos por dois níveis (10 cm de espessura) fossilíferos (Fig.6). $O$ restante da seção é representado por arenito e siltito, com 2 e 4,5m de espessura respectivamente.

\subsection{AFLORAMENTO 2}

Localiza-se à esquerda da estrada secundária que liga Tambaú a Santa Rosa do Viterbo, no Sítio São João do Capão Redondo. Neste afloramento, é encontrada a concentração fossilífera $\mathrm{C}$, atrás da sede do sítio.

$O$ afloramento fossilífero 2 apresenta cerca de $26,5 \mathrm{~m}$ de sedimentos pertencentes à Formação Corumbataí, sendo que o topo do pacote, com cerca de $15 \mathrm{~m}$, encontra-se encoberto por densa vegetação. A base é caracterizada por um pacote de arenito maciço/arenito muito fino, totalizando $3,2 \mathrm{~m}$ de sedimentos, os quais são sucedidos por siltito esverdeado, com fratura conchoidal. Rumo ao topo, aflora novamente um pacote de arenito fino-siltito, verde arroxeado, apresentando estrutura ondulada "wavy" $e$ aproximadamente $0,5 \mathrm{~m}$ de espessura (Fig.7). Sobre este pacote estão sobrepostos os níveis fossiliferos, incluídos em aproximadamente $10 \mathrm{~cm}$ de siltito ou argilito com 
conchas de bivalves variando de dispersas a densamente empacotados na matriz. O pacote final de sedimentos é composto por arenito muito fino, cinza esverdeado, com intercalações de siltito.

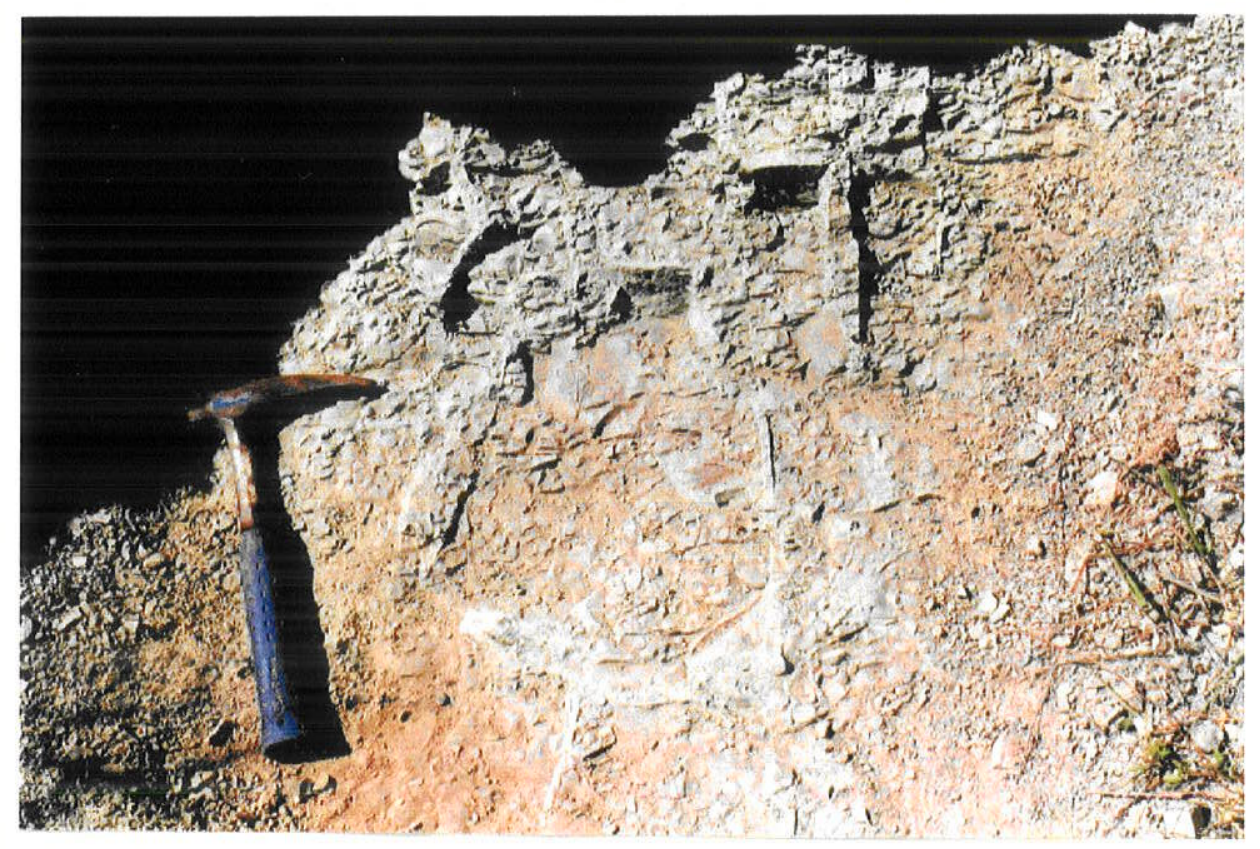

Figura 4. Afloramento 1: gretas de contração em siltito fino.

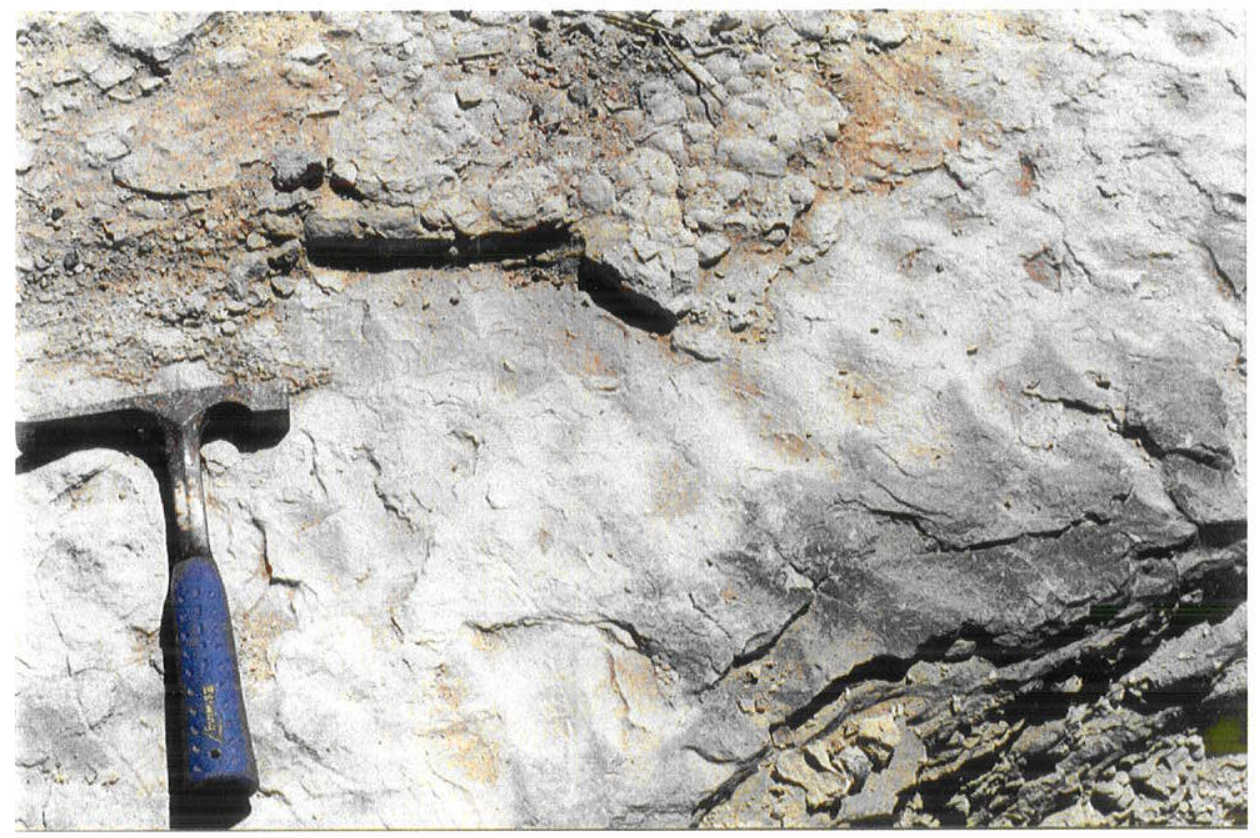

Figura 5. Afloramento 1: marcas onduladas em siltito fino. 


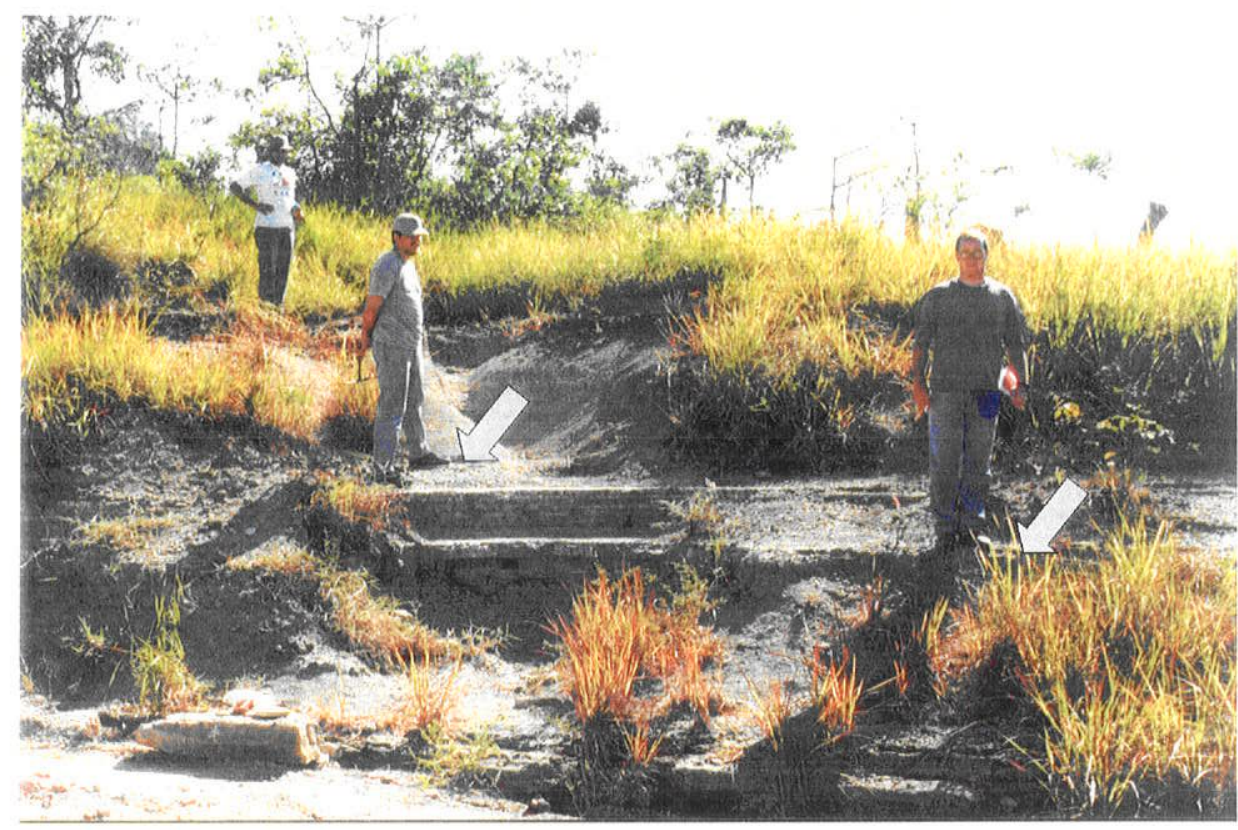

Figura 6. Afloramento 1: níveis fossilíferos A (inferior) e B (superior) (setas).

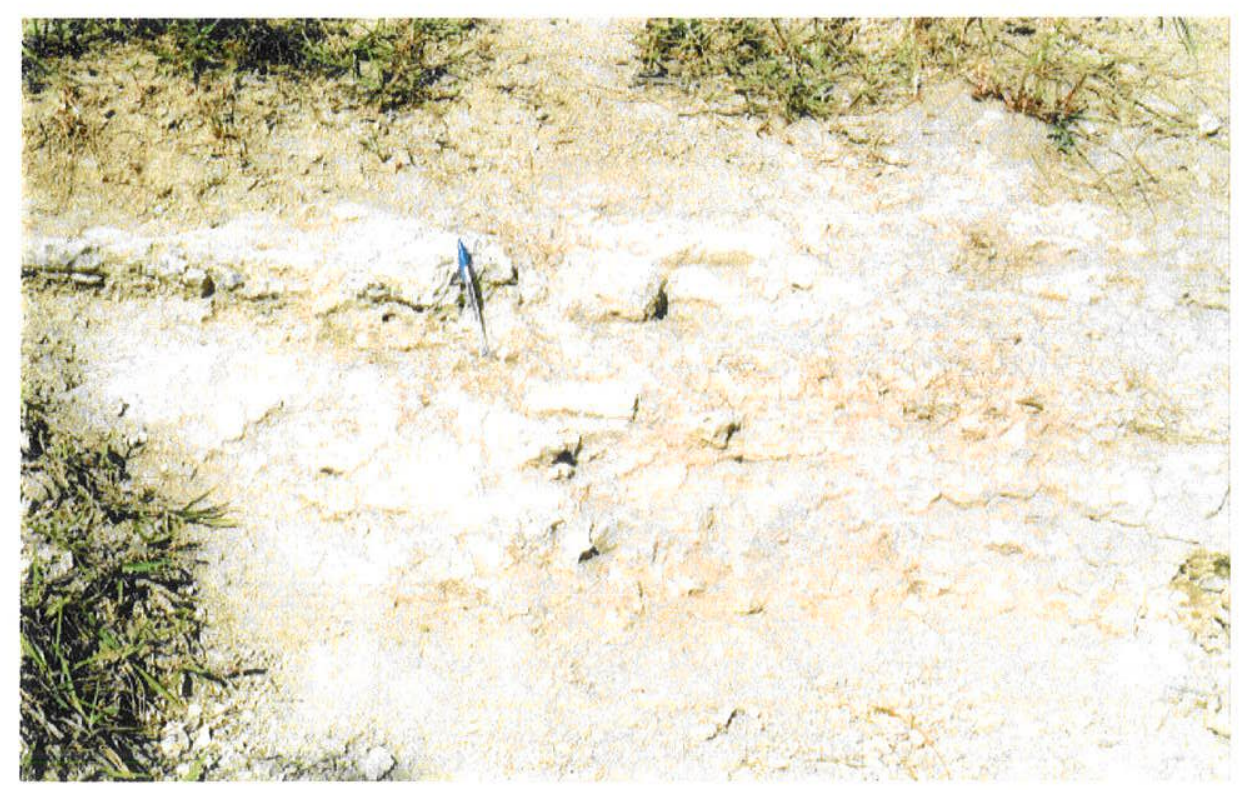

Figura 7. Afloramento 2: Detalhe da concentração C. Observe o alto grau de imtemperismo do arenito fino/siltito. 


\subsection{AFLORAMENTO 3}

Com cerca de $60 \mathrm{~m}$ de espessura exposta, o afloramento situa-se à direita na bifurcação para a Fazenda São Roque, na estrada secundária que liga Tambaú a Santa Rosa do Viterbo, em terras da própria Fazenda São Roque. Este afloramento inclui a concentração fossilífera D.

A seção consiste de $20 \mathrm{~m}$ de sedimentos que podem ser visualizados, sendo que $41 \mathrm{~m}$ de sedimentos da base encontram-se encobertos. Na base, onde começam a aflorar os sedimentos da Formação Corumbataí (Fig.8), está em evidência uma camada de 1,5m de espessura de arenito fino- siltito, roxo-esverdeado, bioturbado, sem laminação ou com laminação muito incipiente, mosqueado. Acima, assentam-se $1,10 \mathrm{~m}$ de argilito esverdeado, com laminação ondulada, lentes de siltito ou arenito muito fino-siltito, com laminação ondulada estão expostos na seqüência. $O$ arenito apresenta cor roxo esverdeado com intercalações de siltito arroxeado esverdeado com laminação plano paralela incipiente e fratura conchoidal. Acima deste, ocorre um pacote de $1,5 \mathrm{~cm}$ de espessura de arenito fino avermelhado, silicificado com acamamento ondulado, apresentando marcas onduladas e gretas de contração. Cerca de 1 metro acima ocorre siltito ou argilito avermelhado, creme quando intemperizado, maciço ou incipientemente laminado com fratura conchoidal, apresentando gretas de contração centimétricas. (Fig.9.) Concreções centimétricas estão dispersas neste litótipo. Assenta-se sobre o siltito uma camada de arenito muito fino creme, maciço com fósseis dispersos. Logo acima aflora nova camada de siltito ( $1 \mathrm{~m}$ ) arroxeado esverdeado com fratura conchoidal/maciço a incipientemente laminado, contendo restos de peixes e passando transicionalmente para uma camada de arenito. O topo da seção é composto predominantemente por arenito fino a médio, maciço, com contato basal brusco e apresentando extensão lateral de aproximadamente $105 \mathrm{~m}$. Neste litótipo valvas desarticuladas de bivalves e ostracodes são freqüentes. 


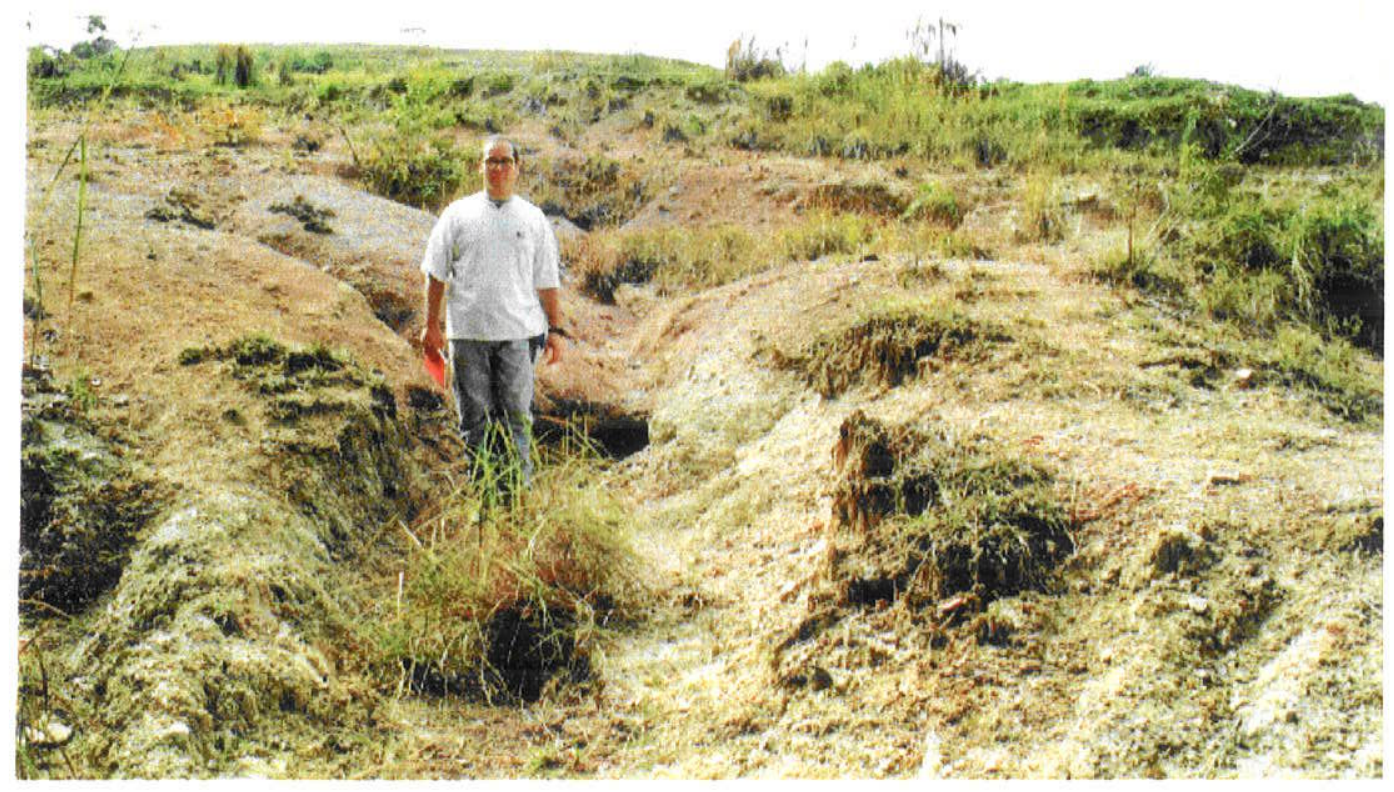

Figura 8. Afloramento 3: Base da seção medida formada de siltito e arenito intercalado.

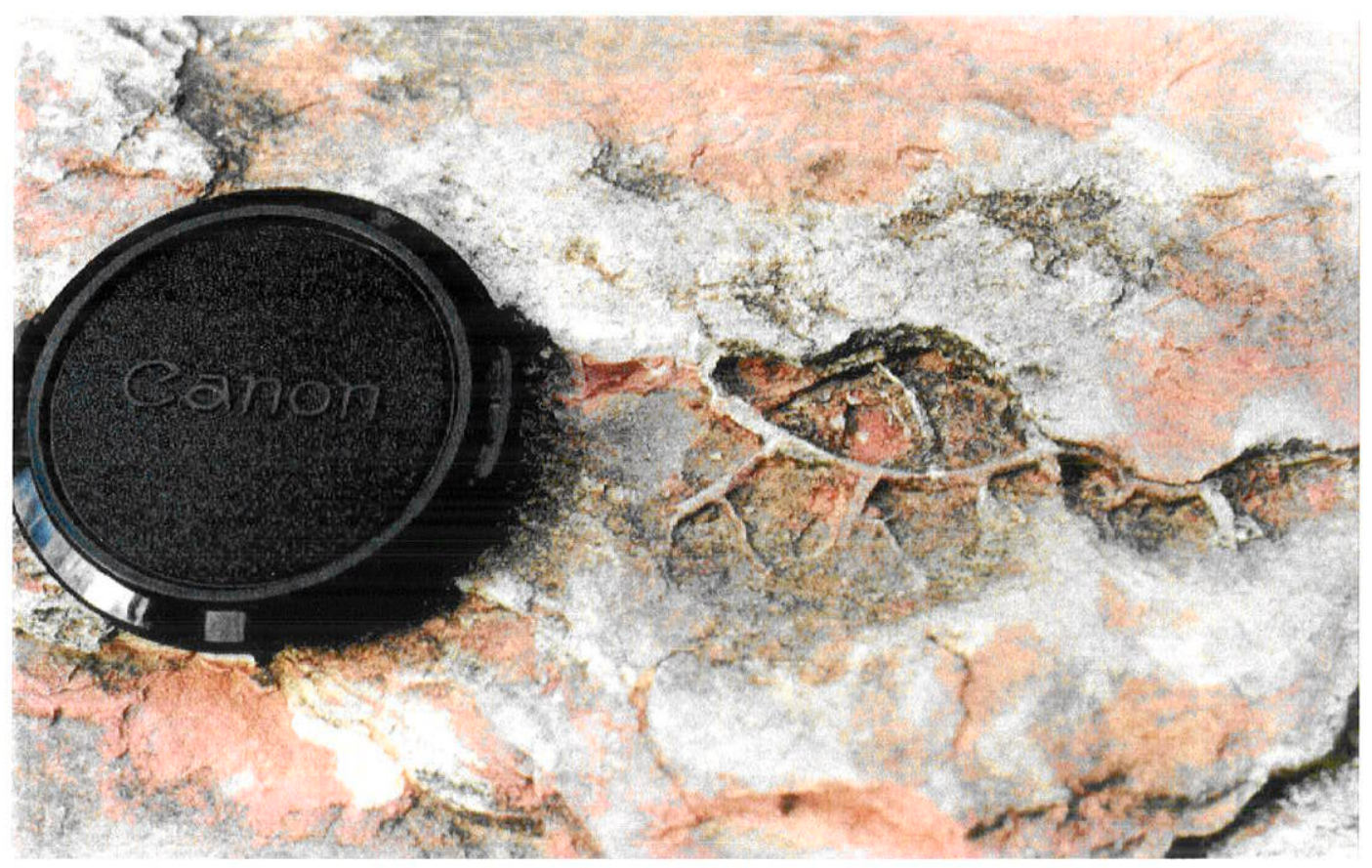

Figura 9. Afloramento 3: Gretas de contração centimétricas em arenito fino. 


\section{TAFONOMIA DAS CONCENTRAÇÕES FOSSHLÍFERAS DO GRUPO PASSA DOIS (PERMIANO SUPERIOR): CONHECIMENTO ATUAL, COM ÊNFASE NAS CONCENTRAÇÕES DE BIVALVES.}

Estudos envolvendo aspectos bioestratinômicos de concentrações fossiliferas do Grupo Passa Dois, cujo início se deu no final da década de 80 , intensificaram-se nos últimos anos (Rohn, 1988).

Uma revisão histórica mostra que os trabalhos publicados até o momento podem ser tentativamente agrupados em quatro fases distintas: a) trabalhos descritivos; b) análise de processos e produtos; e, c) elaboração de modelos de tafofacies.

\subsection{PRIMEIRA FASE: OS TRABALHOS DESCRITIVOS}

Esta fase engloba os trabalhos descritivos, onde a maior parte dos estudos trata da descrição das feições bioestratinômicas presentes nas concentrações fossiliferas, sem se preocupar com a interpretação dos processos sedimentares envolvidos na sua gênese.

Rohn (1988) apresentou o primeiro estudo bioestratinômico de concentrações fossilíferas do Grupo Passa Dois, (envolvendo a Formação Rio do Rasto, Permiano superior, no Estado do Paraná) descrevendo feições tais como desarticulação, biofábrica e fragmentação. Embora não utilize conceitos e critérios modernos para a classificação das assembléias estudadas (Brett e Baird, 1986; Kidwell et al., 1986; Kidwell, 1991; Donovan, 1991; Allison e Briggs, 1991; Kidwell e Bosence, 1991), Rohn (1988) concluiu que as concentrações formavam-se em lagos afetados esporadicamente por fortes tempestades e pela ação de ondas mais fracas.

Em seu estudo sobre a história tafonômica de concentrações fossilíferas do Paleozóico Superior da Bacia do Paraná (formações Rio do Sul, Corumbataí e Terezina), Simões e Rocha-Campos (1993), utilizando o grau de transporte dos bioclastos (Kidwell et al., 1986; Fürsich, 1990), reconheceram a presença de assembléias autóctones (assembléia de Baitaca, Formação Rio do Sul), parautóctones (assembléia de Passinho, Formação Rio do Sul), parautóctones-alóctones (assembléia de Pinzonella illusa, 
Formação Corumbataí) e alóctones (assembléia de Pinzonella neotropica, Formação Corumbataí).

Os autores demonstraram, deste modo, que algumas das assembléias do Grupo Tubarão (Rio da Areia, Taió, Rio Bonito, São Sepé e Palermo) fornecem dados mais adequados a estudos paleoecológicos, enquanto que os do Grupo Passa Dois (assembléias de Pinzonella illusa e Pinzonella neotropica) são particularmente úteis para o entendimento da dinâmica sedimentar. Embora contando com uma quantidade de dados ainda limitada para a época, os autores já vislumbraram a possibilidade das concentrações fossilíferas do Grupo Passa Dois, Formações Corumbataí e Terezina, serem caracterizadas por acentuada mistura espacial, o que seria amplamente comprovado por trabalhos posteriores.

Contemporaneamente, Torello e Simões (1993a, 1994) apresentaram o primeiro estudo bioestratinômico de detalhe para quatro concentrações fossiliferas da região de Rio Claro (Formação Corumbatai), SP, contendo elementos da assembléia de Pinzonella illusa. As principais feições observadas foram: composição taxonômica, biofábrica e estrutura interna, reorientação, desarticulação e fragmentação e bioerosão. Com base nas feições acima, observaram que, nas quatro concentrações fossilíferas estudadas, os bioclastos foram reorientados e misturados com elementos da epifauna bissada. Devido a boa qualidade de preservação, julgaram que os bioclastos sofreram curto transporte lateral, baixa exposição na interface água-sedimento e rápido soterramento, decorrente de aumento brusco na taxa de sedimentação (Torello e Simões, 1993a, 1994). Concluiram, portanto, que as concentrações estudadas são parautóctones a alóctones, geradas por eventos de sedimentação episódica, provavelmente tempestades.

Em uma breve nota, Torello e Simões (1993b) discutiram a questão da desarticulação de conchas de bivalves e suas implicações na interpretação dos processos (e.g. taxa de sedimentação, transporte) relacionados à gênese das concentrações fossilíferas na Formação Corumbataí, região de Rio Claro. Com base nos dados de Allmon (1985) e Brett e Baird (1991), os autores concluiram que a presença de conchas de bivalves articuladas abertas ("butterflied"), nas concentrações de Pinzonella illusa, indica soterramento rápido, porém não instantâneo, por aumento brusco na taxa de sedimentação. Tal condição, está relacionada normalmente a eventos de sedimentação 
episódica (e.g. tempestades), corroborando os dados prévios obtidos (Torello e Simões, 1993a, 1994).

Técnicas de quantificação das características descritivas também foram empregadas na análise de concentrações fossiliferas do Grupo Passa Dois. Simões et al. (1996b), a fim de entenderem o tipo e a intensidade do transporte sofrido por conchas de diferentes espécies de uma mesma acumulação esquelética, da Zona de Pinzonella illusa, examinaram mais de 1200 espécimes silicificados e analisaram o seu grau de abrasão. Esta feição é indicativa de condições hidrodinâmicas e do tempo de exposição na interface água/sedimento à qual as conchas estiveram submetidas. Com base nos dados obtidos, apresentados sob a forma de tafogramas ternários (Kowalewski et al., 1995), os autores concluiram que a presença de conchas de mesmo tamanho, exibindo diferentes graus de abrasão, sugere que a concentração estudada engloba conchas de diferentes gerações.

\subsection{SEGUNDA FASE: PROCESSOS E PRODUTOS}

A partir de 1996, Simões e colaboradores iniciam uma etapa de estudos englobando aspectos bioestratinômicos de concentrações fossiliferas contendo bivalves, tratando dos processos e produtos envolvidos na gênese destas acumulações esqueléticas.

Utilizando-se de feições bioestratinômicas (sensu Fürsich e Oschmann, 1993), Simões et al. (1994) interpretaram as concentrações de bivalves da assembléia de Pinzonella illusa (Formação Corumbataí) da região de Rio Claro, SP, como sendo tempestitos arenosos e coquinas geradas por eventos de alta energia, em ambiente marinho proximal.

Um estudo detalhado da assembléia de Pinzonella neotropica em Camaquã, na parte superior da Formação Corumbataí, região de Rio Claro, SP, foi apresentado por Simões et al. (1996a). Neste estudo, foram amplamente empregados os conceitos estabelecidos por Fürsich e Oschmann (1993), envolvendo a análise de biofábrica e da qualidade de preservação dos biociastos. Os autores notaram que os bioclastos da 
coquina de Camaquã estão caoticamente distribuídos na matriz, densamente empacotados, apresentado diversas classes de tamanho, além de gradação descontínua. Todas as conchas estudadas estão desarticuladas, predominando as desgastadas $e$ fragmentadas. A coquina assenta-se em contato brusco e erosivo, sobre o siltito subjacente. Com base nestas feições, inferiram que a coquina de Camaquã corresponde a um tempestito proximal, gerado provavelmente por fluxo de tempestade.

O trabalho de Simões et al. (1996a) é muito importante no contexto histórico das pesquisas tafonômicas do Grupo Passa Dois por dois motivos: a) pela primeira vez foram reconhecidas, descritas e detalhadamente discutidas feições bioestratinômicas indubitavelmente características de tempestito proximal, sugerindo que o intervalo equivalente a Assembléia de Pinzonella neotropica foi tipicamente caracterizado por eventos de tempestade. Esse fato já havia sido antecipado (Simões e Rocha-Campos, 1992; Torello e Simões, 1993a, 1994), mas não demonstrado e investigado com um número tão acentuado de evidências tafonômicas e sedimentares; b) estudos tafonômicos de coquinas (sensu Kidwell e Bosence, 1991) permianas são raros, uma vez que tais concentrações não são feições comuns no registro paleozóico.

\subsection{A ELABORAÇÃO DE MODELOS DE TAFOFACIES}

A terceira fase abrange estudos envolvendo a elaboração de modelos de tafofacies, cujo início dá-se com a publicação do trabalho de Rohn e Penatti (1993).

A despeito da carência de dados tafonômicos para muitas das concentrações fossiliferas do Grupo Passa Dois, alguns autores (Rohn e Penatti, 1993; Rohn, 1994; Maranhão, 1995; Simões, 1996a,b), trabalhando em áreas onde as concentrações fossiliferas já haviam sido estudadas previamente, apresentaram modelos de facies tafonômicas.

O primeiro modelo de tafofacies foi apresentado por Rohn e Penatti (1993), para concentrações fossilíferas da Formação Terezina dos estados do Paraná e Santa Catarina. Os autores reconheceram quatro facies tafonômicas. A tafofacies 1 representa concentrações fossiliferas geradas por sedimentação rápida, incluindo elementos 
autóctones. As tafofacies 2 e 3 incluem também concentrações geradas por sedimentação rápida onde os bioclastos não exibem uma história de intenso retrabalhamento diário, sendo que a tafofacies 2 inclui valvas inteiras, não selecionadas, pouco ou densamente empacotadas, e a tafofacies 3 apresenta também valvas inteiras, com a superficie convexa para cima e pobremente empacotada. A tafofacies 4 inclui concentrações fossiliferas com história bioestratinômica complexa, contendo valvas muito fragmentadas, raras inteiras, mal selecionadas, não orientadas e densamente empacotadas, correspondendo provavelmente a depósitos condensados proximais.

Rohn (1994) apresentou um novo modelo de facies tafonômicas para as concentrações contendo bivalves das formações Terezina e Rio do Rasto, SC e PR., incluindo material previamente estudado (Rohn e Penatti, 1993). Foram discriminadas oito tafofacies para a Formação Terezina e sete para a Formação Rio do Rasto. Para a Formação Terezina (Assembléia Pinzonella neotropica), 60\% das ocorrências incluemse na tafofacies TE-B-1 que pode passar por transição verticalmente para o tipo TE-B-2 e vice versa, constituindo as tafofacies mais comuns. A tafofacies TE-B-1 consiste de concentrações fossiliferas que incluem val vas isoladas, suportadas pela matriz, dispostas caoticamente, em geral inteiras, sem evidências de abrasão e seleção, enquanto que a tafofacies TE-B-2 é semelhante a TE-B-1 diferindo apenas na tendência a maior orientação das valvas com a superficie convexa para cima. Na Formação Rio do Rasto, a maioria das 125 concentrações analisadas inserem-se na tafofacies RR-B-1, constituída de arenito fino a lamito contendo valvas de bivalves de tamanho variado, isoladas, predominantemente com a convexidade para baixo, articuladas fechadas e "butterflied". Alguns indivíduos parecem estar em posição de vida.

Maranhão (1995), utilizando-se dos mesmos critérios de Rohn (1994) estabeleceu tafofacies para concentrações fossiliferas das formações Estrada Nova e Corumbataí, no Estado de São Paulo. Este modelo não é restrito aos bivalves. Foram definidas 17 tafofacies para a Formação Corumbataí, incluindo uma na parte inferior, dez para a parte média e seis para a parte superior. Na Formação Estrada Nova, foram definidas quatro tafofacies no membro Serra Alta e nove no membro Terezina.

Recentemente, Simões (1996a) propôs um modelo de tafofacies para concentrações fossilíferas de bivalves da Formação Corumbataí. As tafofacies foram 
distinguidas através das assinaturas tafonômicas, determinadas pela biofábrica e qualidade de preservação dos bioclastos. As tafofacies propostas foram fundamentadas nos critérios estabelecidos por Brett e Baird (1986) e Speyer e Brett (1986, 1991), incluindo três tafofacies, informalmente designadas através de números.

A tafofacies 1 representa o ambiente bioestratinomicamente mais destrutivo, com altos valores de desarticulação, reorientação, seleção, fragmentação e abrasão das conchas. A tafofacies 2 é similar à 1, porém algumas conchas apresentam melhor qualidade de preservação, que pode estar associado ao aumento no aporte de sedimento. Já na tafofacies 3, parece ter ocorrido rápido soterramento, portanto, algumas conchas apresentam-se articuladas fechadas.

Todas as tafofacies definidas por Simões (1996a) foram geradas em condições de águas rasas. A distribuição vertical das tafofacies descritas mostra que episódios associados a tempestades foram muito comuns durante a deposição da Formação Corumbataí e que a taxa de sedimentação foi um fator importante na gênese das concentrações fossiliferas (Simões, 1996a).

Os modelos de tafofacies que mais se aproximam do conceito originalmente proposto por Speyer e Brett $(1986,1988)$ e Brett e Baird (1986) são os de Rohn e Penatti (1993) e Simões (1996a). Os dois modelos propõem um número reduzido de tafofacies, incluindo em cada uma delas estratos de mesma característica bioestratinômica, não importando a unidade litoestrarigráfica a que pertencem, nem a assembléia fossilífera que incluem.

Com relação às semelhanças existentes entre os modelos de tafofacies propostos por Rohn e Penatti (1993) e Simões (1996a), é curioso notar que, mesmo os modelos tendo sido propostos para concentrações fossilíferas provenientes de localidades distintas (afloramentos de SC e PR da Formação Terezina e região central do Estado de São Paulo, respectivamente), as tafofacies assemelham-se muito quanto às características bioestratinômicas, como demonstra a Tabela 1. A despeito dos modelos serem estabelecidos para regiões distintas e envolvendo concentrações fossiliferas em posição estratigráfica também variada, os resultados sugerem não apenas recorrência de tafofacies ao longo da sucessão sedimentar do Grupo Passa Dois, mas também que os dois modelos propostos podem ser utilizados para áreas geograficamente afastadas. 


\subsection{MISTURA TEMPORAL E RETROALIMENTAÇÃO TAFONÔMICA}

A quarta fase de estudos tafonômicos é marcada pela investigação da questão da mistura temporal ("time averaging") e espacial em concentrações fossilíferas internamente complexas, como ponto de partida para discussões mais amplas envolvendo aspectos teóricos e metodológicos da paleontologia.

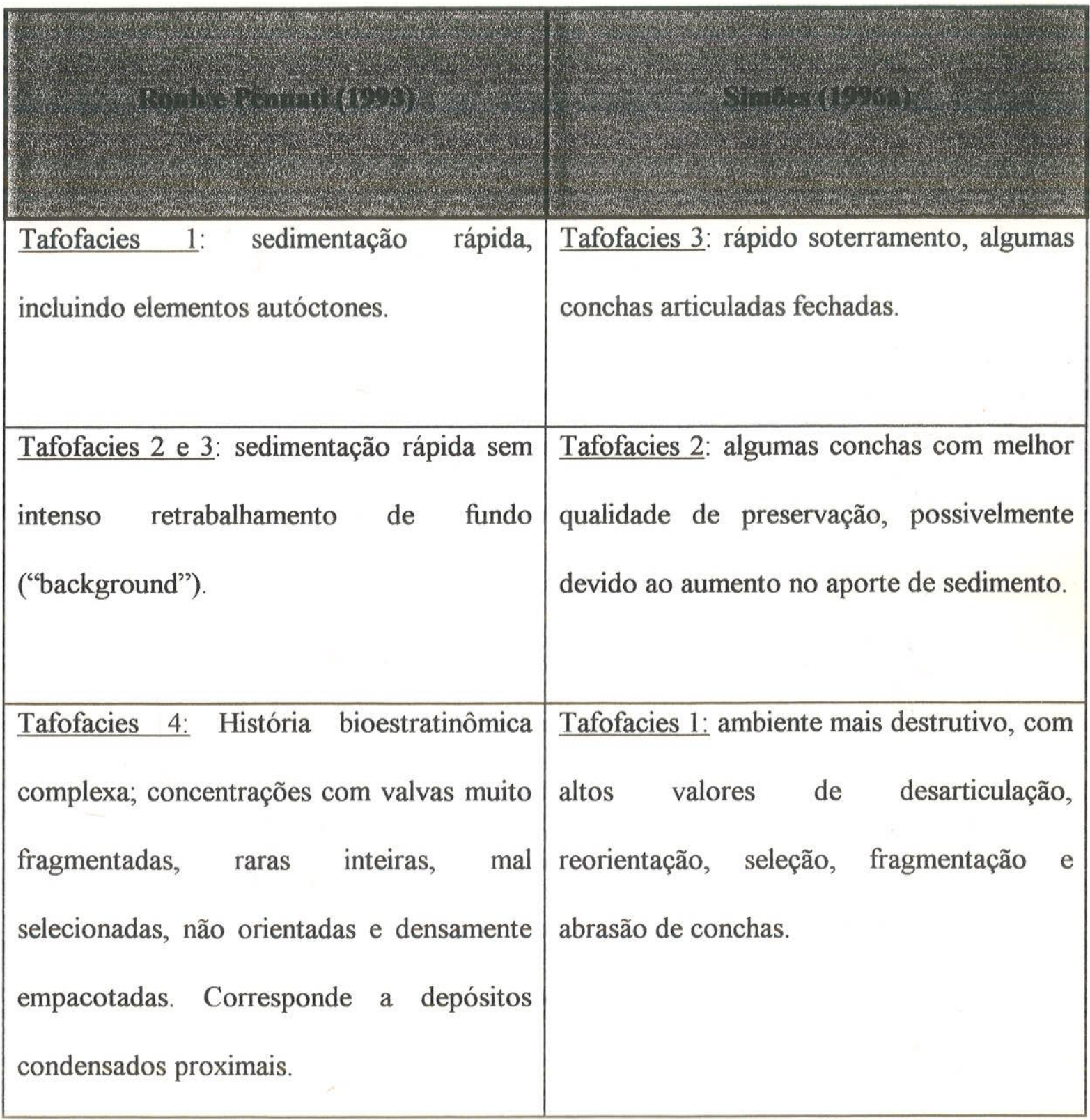

Tabela 1. Comparação entre tafofacies propostas por Rohn e Penatti (1993) e Simões (1996a) para o Grupo Passa Dois, Bacia do Paraná. 
Recentemente, vários estudos têm abordado a questão da mistura temporal ("time averaging") de concentrações fossilíferas do Grupo Passa Dois (Klein, 1997; Klein et al., 1997a,b; Simões, 1998; Simões e Kowalewski,1998 a,b; Simões et al., submetido).

Klein (1997) e Klein et al. (1997a,b) demonstraram a história complexa da concentração fossilifera, de Tiarajú (Formação Terezina), RS, indicada pela presença de mistura de conchas articuladas, sem sinais de abrasão, com conchas que sofreram algum grau de abrasão, conchas desarticuladas e valvas com a cavidade preenchida por litologia diferente da matriz em que se encontram. A associação de conchas articuladas fechadas, preenchidas com litologia igual e diferente aquela da matriz, reflete mistura de elementos esqueléticos mais antigos com elementos de assembléia mais recente, através de processos de exumação e retrabalhamento, indicando assim certo grau de mistura temporal.

Simões (1998) comparou dados obtidos de arenitos bioclásticos das formações Terezina e Corumbataí (e.g., Ferraz, Rio Claro, São Paulo), com os de arenitos bioclásticos das formações Rio Bonito (Permiano inferior) e Palermo (Permiano superior), todos gerados em condições de águas rasas, através de eventos de alta energia (tempestades). As concentrações não são geneticamente simples, possuem bioclastos exibindo diferentes graus de preservação, mistura de organismos com diferentes modos de vida, de substratos bentônicos distintos e apresentam internamente horizontes descontínuos. $O$ autor conclui que concentrações fossilíferas como as de Ferraz são geneticamente complexas, apresentam alto grau de mistura temporal e constituem um registro paleontológico heterogêneo do espectro de ecossistemas que existiram numa área deposicional, ao longo de um período de tempo estimado entre $10^{2}-10^{4}$ anos, segundo os dados disponíveis para as acumulações esqueléticas semelhantes do Recente.

Simões et al. (1998a,b; submetido) analisaram o grau de mistura temporal de depósitos recobertos abruptamente por sedimento fino, o que caracteriza depósitos de "obrution" (sensu Seilacher et al., 1985; Brett e Seilacher, 1991), em concentrações do Grupo Passa Dois e do Devoniano da Bacia do Parana. Estes depósitos apresentam animais em excelente estado de preservação, comumente preservados "in situ", interpretados como temporalmente bem resolvidos. Porém, apesar de se tratar de um 
depósito de "obrution", pode-se verificar um acentuado grau de mistura temporal ("time averaging") quando o horizonte soterrado é analisado, apesar de serem encontrados elementos da epifauna preservados em posição de vida (Simões et al., 1998a,b; submetido). Os bioclastos presentes no horizonte soterrado apresentam-se, em sua maioria, desarticulados, fragmentados, densamente empacotados e associados a elementos da epifauna, evidenciando o acentuado grau de mistura temporal.

Poucos são os estudos que incluem a análise do processo de retroalimentação tafonômica de concentrações fossilíferas do Grupo Passa Dois. Isto se deve ao fato de eventos deste tipo serem de difícil identificação, em decorrência da mistura imposta pela sobreposição dos processos tafonômicos de fundo e episódicos (Simões, 1998).

Simões e Rocha Campos (1992), com base nos dados de Rohn e Fairchild (1986), interpretaram a ocorrência de conchas de bivalves que serviram de substrato duro e estável para o desenvolvimento de estromatólitos, como exemplo de retroalimentação tafonômica na Formação Rio do Rasto (Permiano superior), discutindo as suas implicações na bioestratigrafia do Grupo Passa Dois.

Recentemente, Simões (1998) e Simões e Kowalewski (1998a,b) identificaram um evento de retroalimentação tafonômica na concentração fossilífera de Ferraz (Formação Corumbatai), Rio Claro, onde a mistura de elementos com diferentes modos de vida (e.g., escavador lento e epifauna bissada) indica a impossibilidade de coexistência destas espécies sobre o mesmo tipo de substrato, o que caracterizaria a uma "assembléia espacialmente misturada". A mistura de bivalves com diversos modos de vida pode resultar da ocorrência de mudanças na natureza do substrato ao longo do tempo, caracterizando assim o evento de retroalimentação tafonômica. 


\section{CRITÉRIOS PARA CLASSIFICAÇÃO DE CONCENTRAÇÕES FOSSILÍFERAS MARINHAS}

As concentrações fossiliferas marinhas foram classificadas de maneiras distintas por diversos autores nos últimos 40 anos (e.g., Johnson, 1960; Aigner et al., 1978; Fürsich, 1982; Kidwell, 1991). A diferença entre as diferentes propostas deve-se aos critérios distintos utilizados na elaboração das classificações. Diversos têm sido os critérios empregados, tais como: paleoecológico, temporal, estratigráfico, geométrico, história de acumulação e critérios genéticos. As principais classificações fundamentadas nos critérios citados acima, a partir da década de 60 , serão comentadas a seguir.

\subsection{CRITÉRIO PALEOECOLÓGICO}

Kidwell et al. (1986) classifica as assembléias fossiliferas de acordo com seu grau de transporte em relação ao seu substrato original, utilizando, portanto, um critério paleoecológico. Esta abordagem é também utilizada por Johnson (1960), Fagerstrom (1964) e Scott (1970). (Tabela 2.)

As assembléias autóctones (Kidwell et al., 1986), formadas por espécimes derivados da comunidade local e preservados em posição de vida, correspondem ao modelo I (assembléia soterrada rapidamente) de Johnson (1960), a comunidade fóssil de Fagestrom (1964) e a "in place community" de Scott (1970).

As assembléias parautóctones são compostas por espécimes autóctones que foram retrabalhados, porém não transportados para fora de seu habitat original de vida (Kidwell et al., 1986). Estes espécimes podem também ser reorientados, desarticulados e concentrados através de agentes biológicos como organismos bioturbadores $\mathrm{e}$ escavadores, além de processos físicos. Este tipo de assembléia corresponde ao modelo II (acumulação gradual de conchas autóctones) de Johnson (1960), a assembléia fóssil residual de Fagestrom (1964) e a "disturbed Neighborhood assemblage" de Scott (1970). 


\begin{tabular}{|c|}
\hline \\
\hline $\begin{array}{l}\text { Assembléia } \\
\text { rapidamente: } \\
\text { soterrados em posição de vida } \\
\text { com mínimo distúrbio. Alta } \\
\text { proporção de espécimes } \\
\text { articulados, baixo grau de } \\
\text { fragmentação e abrasão. }\end{array}$ \\
\hline $\begin{array}{l}\text { Acumulacão gradual de } \\
\text { conchas autóctones: assembléia } \\
\text { intermediária, com mistura de } \\
\text { elementos alóctones, expostos } \\
\text { ao retrabalhamento. Moderada } \\
\text { proporção de bioclastos } \\
\text { fragmentados, exibindo vários } \\
\text { graus de abrasão. Maioria dos } \\
\text { bioclastos disposta } \\
\text { paralelamente ao acamamento. }\end{array}$ \\
\hline $\begin{array}{l}\text { Concentraça de conchas } \\
\text { alóctones: assembléia composta } \\
\text { quase totalmente de bioclastos } \\
\text { transportados, alta proporção } \\
\text { de bioclastos fragmentados. } \\
\text { Vários graus de abrasão. } \\
\text { Maioria dos bioclastos } \\
\text { dispostos paralelamente ao } \\
\text { plano de acamamento. }\end{array}$ \\
\hline
\end{tabular}

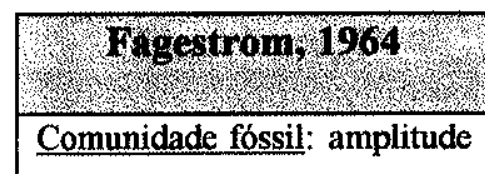

grande de tamanho dos indivíduos e a classe modal contém grande número de espécimes pequenos.

(1)

\section{Assembléia} residual: predominância de indivíduos grandes. Assembléia formada a partir de correntes aquosas de alta competência e de eficiente poder de seleção.

Assembléia transportada:
Seleção de conchas pelo
tamanho durante o transporte
através de correntes.

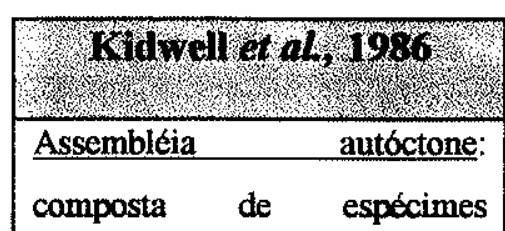

derivados da comunidade local e preservados em posição de vida.

\section{Assembléias parautóctones: compostas de espécimes} autóctones retrabalhados de alguma maneira, porém não transportados para fora de seu habitat de vida.

Assembléias $\quad$ alóctones:
assembléia composta de
espécimes transportadas para
fora de seu habitat de vida.

Tabela 2. Classificações de concentrações fossilíferas de acordo com o critério paleoecológico. 
As assembléias alóctones consistem de espécimes transportados para fora de seu habitat de vida (Kidwell et al., 1986). Correspondem ao modelo III (concentração de conchas alóctones) de Johnson (1960) e assembléia transportada de Fagerstrom (1964) e Scott (1970).

As diferentes classificações disponiveis são importantes, uma vez que os diversos tipos propostos demonstram o caráter ecológico de cada assembléia, onde os elementos foram ou não transportados ou apresentam-se em posição de vida, fazendo com que os elementos presentes no momento do soterramento final abrupto possam ser identificados e a paleoecologia da comunidade reconstituída com certa precisão. Por outro lado, os ambientes em que as concentrações fossilíferas foram depositadas foi pouco explorado pelos autores, bem como os processos que levaram à acumulação de partes duras.

\subsection{CRITÉRIO TEMPORAL}

Classificações de concentrações fossiliferas marinhas com base na idade relativa dos depósitos foram propostas por Kidwell e Bosence (1991) e Brett e Baird (1993), (Tabela 3) dentre outros. Ambas classificações são extremamente semelhantes, como apontado por Brett e Baird (1993).

\subsection{HISTÓRIA DE ACUMULAÇÃo}

Classificações baseadas na história da acumulação, que levam em conta o número de eventos que atuaram na gênese da concentração fossilifera, foram propostas por inúmeros autores, dentre eles: Aigner et al. (1978), Fürsich (1982) e Kidwell (1991). (Tabela 4.) Tais propostas diferem muito entre si, incluindo tipos diferentes de assembléias com denominações também distintas. 


\begin{tabular}{|c|}
\hline \\
\hline $\begin{array}{l}\text { Assembléia autóctone ("census"): resultado de } \\
\text { soterramento rápido podendo conter pouco ou } \\
\text { nenhuma mistura temporal. Podem estar } \\
\text { preservadas feições como relações de } \\
\text { comensalismo, preferência por substrato e } \\
\text { espaçamento individual. }\end{array}$ \\
\hline $\begin{array}{l}\text { bléia apresentando mistura temporal } \\
\text { do habitat: mistura de conchas com } \\
\text { tes graus de destruição física, biologica ou } \\
\text { a. Heterogeneidade devido } \\
\text { Ihamento físico ou biogênico. }\end{array}$ \\
\hline $\begin{array}{l}\text { Assembléia condensada ambientalmente: faunas } \\
\text { representando diferentes ambientes no tempo. } \\
\text { Acumuladas em um único horizonte } \\
\text { estratigráfico. Presença de feições indicativas de } \\
\text { múltiplos ciclos de soterramento e exumação, } \\
\text { diagênese precoce e colonização bentônica, }\end{array}$ \\
\hline
\end{tabular}

\begin{tabular}{l}
\hline Camada fossilífera de um único evento: inclui as \\
seguintes opsóes: mortalidade em massa sem \\
soterramento rápido; mortalidade com soterramento \\
rápido; camadas de conchas alóctones; camadas de \\
conchas autóctones. \\
Camada fossilífera composta: múltiplos episódios \\
de soterramento, exumação e soterramento dos \\
bioclastos. Camadas com centímetros de espessura \\
e lateralmente persistente por alguns metros. \\
Acumulação lacunar (condensada) e residual (lag): \\
acumulações finas com relação aos depósitos \\
próximos de mesma idade. Formam-se por \\
acumulação lenta.
\end{tabular}

Tabela 3. Classificação de concentrações fossiliferas marinhas levando-se em conta o critério temporal. 

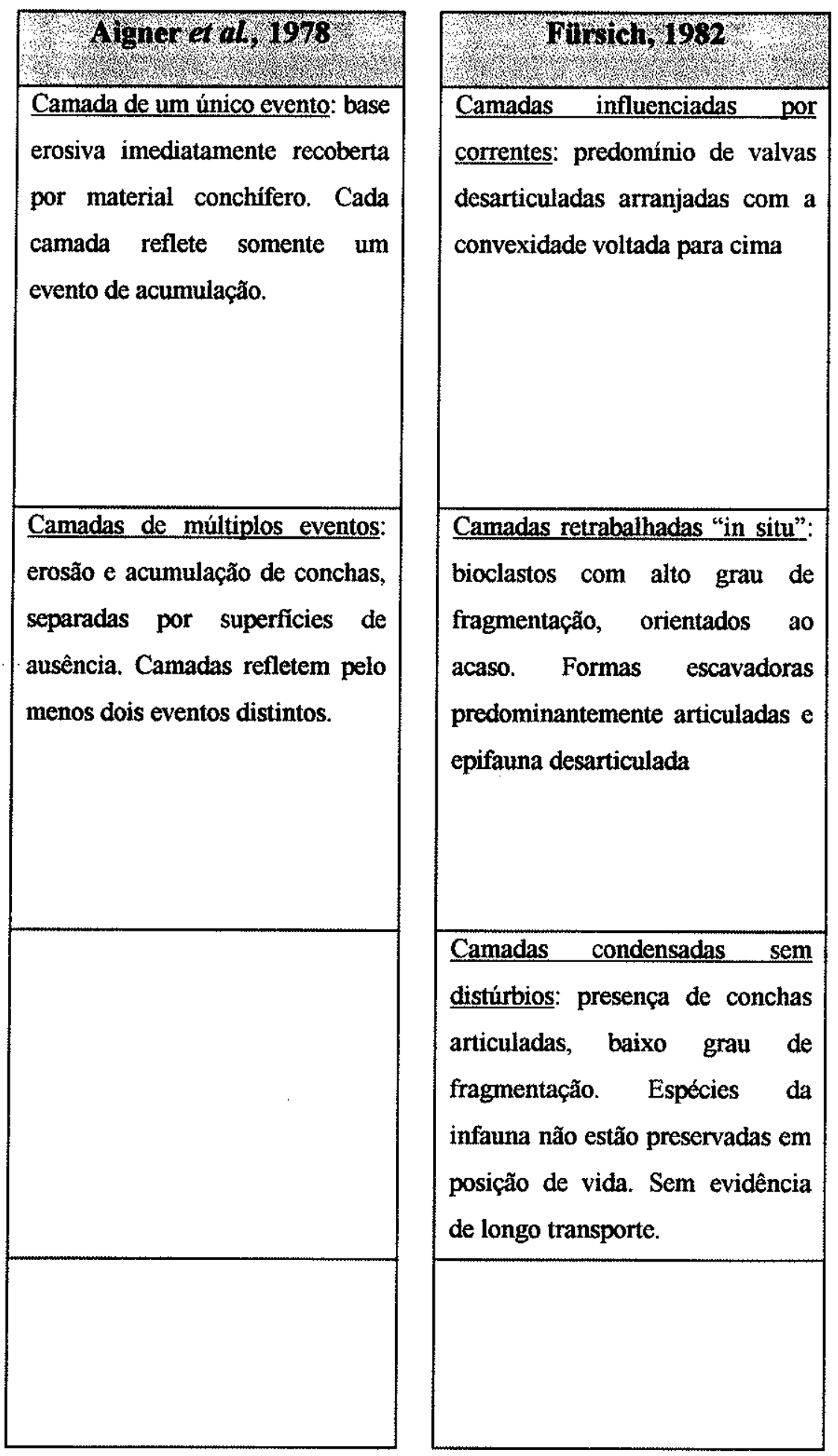

\begin{tabular}{|c|}
\hline S \\
\hline $\begin{array}{l}\text { Concentracão episódica: } \\
\text { assinaturas tafonômicas variáveis, } \\
\text { dependendo da origem e história } \\
\text { de acumulação dos bioclastos, do } \\
\text { agente de concentração e da } \\
\text { exposição no fundo oceânico. } \\
\text { Bioclastos variam de bem } \\
\text { preservados a altamente } \\
\text { fragmentados/selecionados. }\end{array}$ \\
\hline $\begin{array}{l}\text { Concentracão } \\
\text { assinaturas } \\
\text { grandemente tafonômicas } \\
\text { dependendo do tipo de evento de } \\
\text { concentração, da origem e história } \\
\text { do acréscimo, retrabalhamento } \\
\text { subsequente e amalgamamento } \\
\text { inicial, além de exposição no } \\
\text { fundo oceânico. }\end{array}$ \\
\hline $\begin{array}{l}\text { Concentração lacunar: mistura de } \\
\text { conchas bem preservadas } \\
\text { conchas } \\
\text { modificadas. Danos após a morte } \\
\text { podem ser físicos ou biogênicos, } \\
\text { porém as conchas foram } \\
\text { retrabalhadas repetidamente. }\end{array}$ \\
\hline $\begin{array}{l}\text { Concentracão residual (lag): } \\
\text { mistura de conchas inteiras e } \\
\text { fragmentadas. Empacotamento } \\
\text { frouxo a denso. }\end{array}$ \\
\hline
\end{tabular}

Tabela 4. Classificações de concentrações fossiliferas marinhas de acordo com a história de acumulação. 
Uma crítica que se pode fazer às classificações acima é que a história de acumulação das concentrações fossiliferas não leva em conta os processos atuantes na sua geração. Por exemplo, Fürsich (1982) considera que concentrações fossiliferas tanto do tipo 1, quanto do tipo 2 (Tabela 4) poderiam ter sido influenciadas por correntes, durante alguma etapa de sua gênese, em diversos ambientes. Na classificação de Aigner et al. (1978), a camada resultante de um único evento ou de múltiplos eventos poderia ter sido formada pelo mesmo tipo de evento. O mesmo ocorre na classificação de Kidwell (1991), pois uma concentração do tipo composta é também episódica, o que denota inconsistência dos critérios utilizados.

\subsection{CONTEXTO ESTRATIGRÁFICO}

A classificação proposta por Kidwell (1985) envolve concentrações reconhecidas pela autora de acordo com a superficie de recobrimento e/ou a superfície na qual a concentração fossilífera está depositada (Tabela 5). Porém, nesta classificação, as concentrações fossilíferas são criadas de acordo com o grau de sedimentação, que é considerado constante, fato que é raro na natureza, além de processos de acumulação episódica poderem ocorrer e aumentar abruptamente o aporte de partes duras. Desta maneira, na natureza, o grau de sedimentação e aporte de partes duras pode variar muito, sendo raro ocorrer concentrações fossiliferas apresentando os padrões especificados no modelo de classificação de Kidwell (1985). 


\begin{tabular}{l}
\hline Concentração recoberta por superficie de omissão: grau de empacotamento aumenta para o topo, grau de \\
sedimentação aproxima-se de zero ou valor negativo. \\
\hline Concentraçáo recoberta por superficie de erosão: igual a 1, porém a concentração é recoberta por \\
superficie erosiva \\
Concentração depositada sobre superficie de omissão: taxa de acumulação de sedimentos, aumentando \\
para cima excedendo o aporte de partes duras. \\
\hline Concentracão depositada sobre supperficie de erosão: igual a 3 porém, o contato inferior é erosivo. \\
\hline Composto 1 e 3
\end{tabular}

Tabela 5. Classificação de Kidwell (1985) com base no contexto estratigráfico.

\subsection{GEOMETRIA}

A geometria dos corpos das concentrações fossilíferas foi utilizada para classificar concentrações fossilíferas marinhas por Parsons et al. (1988) e Eyles e Lagoe (1989). Além de tratar da geometria dos corpos, Parsons et al. (1988) utilizaram a tafonomia comparada para determinar o modo de formação de depósitos de mares epicontinentais antigos (Tabela 6). Segundo Parsons et al. (1988), tanto as camadas complexas como as condensadas podem se apresentar sob a forma de pavimentos, implicando uma mistura entre o caráter geométrico e história de acumulação. 


\begin{tabular}{|c|}
\hline 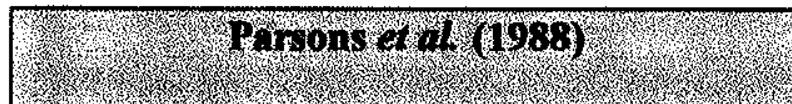 \\
\hline $\begin{array}{l}\text { avimento e cordóes: base da camada contendo } \\
\text { ementos articulados e topo da camada também com } \\
\text { ementos articulados e animais de esqueleto ramoso } \\
\text { reservados. }\end{array}$ \\
\hline $\begin{array}{l}\text { Camadas de conchas simples: contato basal brusco; } \\
\text { presença de elementos esqueléticos fragmentados. } \\
\text { Topo da camada com preservação de organismos "in } \\
\text { situ". }\end{array}$ \\
\hline $\begin{array}{l}\text { Camadas de concha complexa: base brusca com } \\
\text { fragmentos de conchas depositadas em calhas e topo } \\
\text { apresentando conchas e esqueletos preservados "in } \\
\text { situ". }\end{array}$ \\
\hline $\begin{array}{l}\text { Camada de conchas condensada: base brusca } \\
\text { apresentando calhas preenchidas por partes duras } \\
\text { resistentes, fósseis que sofreram corrosão, nódulos } \\
\text { fosfáticos ou concentrações lacunares. Topo } \\
\text { composto por bioclastos que sofreram corrosão, além } \\
\text { de partes duras resistentes (material fóssil bem } \\
\text { preservado). }\end{array}$ \\
\hline
\end{tabular}

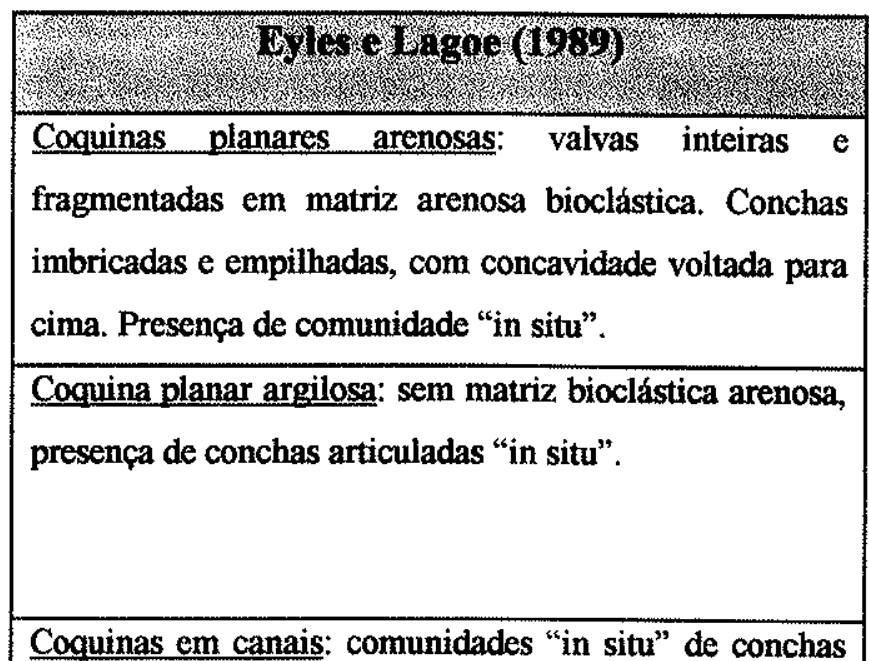
articuladas de braquiópodes e tubos.

Tabela 6. Classificações de concentrações fossiliferas marinhas com base na geometria da concentração esquelética.

\subsection{CRITÉRIO GENÉTICO}

A classificação genética mostrou-se mais apropriada à caracterização dos diversos tipos de concentrações fossiliferas marinhas. Segundo Fürsich e Oschmann (1993), classificações descritivas utilizadas anteriormente não obtiveram muito sucesso por utilizarem características, tais como: espessura da camada, biofábrica, composição taxonômica e qualidade de preservação, que não demonstram as relações entre os 
processos deposicionais particulares. Isto ocorre porque as mesmas feições descritivas podem resultar de processos diferentes, além de muitas concentrações de conchas possuírem natureza complexa.

Além de Fürsich e Oschmann (1993), classificações genéticas de tipos de concentrações fossiliferas marinhas foram propostas por Norris (1986) e Meldhal (1993). (Tabela 7.)

De acordo com as análises de Norris (1986), depósitos de conchas de ambiente marinho raso diferem significantemente de concentrações de ambiente profundo, no que diz respeito a sua freqüência, modo de formação e conteúdo de informação tafonômica e paleoecológica. Estas diferenças resultam de variações na taxa de sedimentação e intensidade do retrabalhamento fisico e biológico.

Nota-se, entretanto, que nem todos os tipos de concentrações propostas pelo autor estão fundamentadas em elemento genético. As camadas de comunidade ("community bed") e as camadas de ossos poderiam corresponder a camadas de tempestade, pois há grande probabilidade de terem sido geradas por esse processo.

Meldhal (1993) ressalta ainda que a camada de comunidade ("community bed") representa uma concentração biogênica, enquanto as demais concentrações representam concentrações sedimentológicas, ou seja, formadas através de eventos de curta duração ("storm bed") ou dinâmica de longa duração ("beach berm bed", "tidal channel bed" e "current/wave winnowed bed").

A classificação proposta por Fürsich e Oschmann (1993) baseia-se na análise de assinaturas tafonômicas e biofábrica das concentrações fossilíferas. Nove tipos de concentrações esqueléticas foram reconhecidos, relacionadas aos diferentes segmentos do perfil praia-costa afora. Os autores ressaltam que as concentrações são raramente restritas a um ambiente particular, mas são mais comuns em alguns ambientes do que em outros (Fig. 10).

Alguns processos responsáveis pela formação de concentrações, identificados por Fürsich e Oschmann (1993), são restritos a um ambiente bem definidos (e.g., ondas de bom tempo), e outros ocorrem ao longo de todo o gradiente de águas rasas e profundas (e.g., correntes de longa duração). 


\begin{tabular}{|c|c|}
\hline 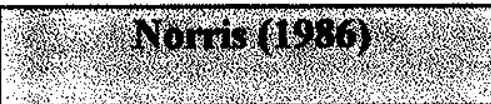 & 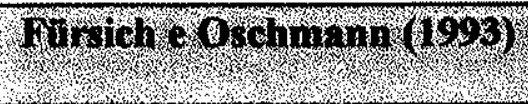 \\
\hline $\begin{array}{l}\text { Camada de tempestade: base } \\
\text { erosiva, bioclastos bem } \\
\text { preservados, presença de } \\
\text { bivalves articulados e conchas } \\
\text { com a concavidade voltada para } \\
\text { baixo }\end{array}$ & $\begin{array}{l}\text { Concentraḉes geradas por onda de } \\
\text { bom tempo: suportada por } \\
\text { bioclastos, seleção de elementos } \\
\text { esqueléticos é pequenas. Alguns } \\
\text { gastrópodes exibem intensa abrasão } \\
\text { e mais de } 2 / 3 \text { apresenta sinais de } \\
\text { fragmentação. Ausência de conchas } \\
\text { incrustadas ou predadas. }\end{array}$ \\
\hline $\begin{array}{l}\text { Camada selecionada por } \\
\text { corrente: conchas fragmentadas, } \\
\text { com abrasăo, desarticuladas, } \\
\text { distribuídas caoticamente, } \\
\text { presença comum de conchas } \\
\text { imbricadas e aninhadas, além de } \\
\text { conchas articuladas. }\end{array}$ & $\begin{array}{l}\text { Concentração gerada por onda de } \\
\text { tempestade: melhor qualidade de } \\
\text { preservação dos elementos } \\
\text { esqueléticos. Base erosiva, seleção } \\
\text { bimodal, orientação em planta ao } \\
\text { acaso. Ausência de sinais de } \\
\text { abrasão, bioerosão ou incrustação. }\end{array}$ \\
\hline $\begin{array}{l}\text { Camada de ossos (Bone bed) } \\
\text { presença de ossos sem alteração } \\
\text { a arredondados e pré- } \\
\text { fossilizados, moluscos } \\
\text { freqüentemente fragmentados, } \\
\text { sendo que alguns ocorrem } \\
\text { articulados, fechados, em } \\
\text { posição de vida. }\end{array}$ & $\begin{array}{l}\text { Tempestito proximal: alta } \\
\text { qualidade de preservação dos } \\
\text { elementos esqueléticos. Biofábrica } \\
\text { indicativa de transporte. Conchas } \\
\text { raramente fragmentadas, com } \\
\text { pouca abrasão e sem bioerosão e } \\
\text { incrustação. }\end{array}$ \\
\hline $\begin{array}{l}\text { Camada de comunidade } \\
\text { (Community bed): aglomerados } \\
\text { de conchas preservadas em } \\
\text { posição de vida; fósseis às vezes } \\
\text { do mesmo tamanho; uma ou } \\
\text { duas espécies dominam cada } \\
\text { assembléia. }\end{array}$ & $\begin{array}{l}\text { Tempestito distal: diferem dos } \\
\text { tempestitos proximais por tenderem } \\
\text { a ser menos espessos, apresentar } \\
\text { melhor seleçâ e tamanho dos } \\
\text { bioclastos menor. }\end{array}$ \\
\hline $\begin{array}{lr}\text { Camada } & \text { ecologicamente } \\
\text { condensada: } & \text { horizontes } \\
\text { altamente bioturbados, com } \\
\text { características de camada de } \\
\text { comunidade e camada } \\
\text { selecionada por corrente. }\end{array}$ & $\begin{array}{l}\text { Concentracães geradas por } \\
\text { correntes: biofábrica composta por } \\
\text { conchas desarticuladas, com } \\
\text { convexidade voltada para cima, } \\
\text { pobremente selecionados e } \\
\text { suportados por bioclastos. Maioria } \\
\text { com alta abrasão. }\end{array}$ \\
\hline & $\begin{array}{l}\text { Concentracão } \text { primariamente } \\
\text { biogênica: baixa seleção, conchas } \\
\text { freqüentemente articuladas e } \\
\text { raramente fragmentadas, sem } \\
\text { sinais de abrasão e bioerosão. } \\
\text { Ocorre incrustação. }\end{array}$ \\
\hline
\end{tabular}

\begin{tabular}{|c|}
\hline 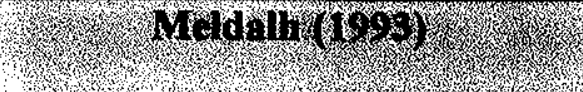 \\
\hline $\begin{array}{l}\text { Depósito de tempestade: depósito com } \\
\text { base erosiva, estratificação } \\
\text { hummocky, decréscimo da densidade } \\
\text { de conchas da base para o topo. } \\
\text { Presença de bivalves articulados } \\
\text { fechados e reorientados. Algumas } \\
\text { conchas com baixo grau de abrasão, } \\
\text { fragmentação, bioerosão } \\
\text { encrustação. }\end{array}$ \\
\hline
\end{tabular}

Depósito retrabalhado por ondas e correntes: contato inferior brusco, raramente suporatda por bioclastos, altamente fragmentados e abradidos, raras valvas articuladas ou ausentes. Bioerosão e encrustação alta.

Canais de costa: longos canais ao longo da costa, predominância de valvas desarticuladas, bioclastos suportada, bioturbação limitada a rara, maioria das valvas com concavidade para cima. Ocorrem conchas aninhadas, conchas com alta brasão, com bioerosão e sem encrustação.

Camada de comunidade: comunidade autóctone, com bivalves em posição de vida, alto índice de valvas articuladas, baixo índice de abrasão $\mathrm{e}$ fragmentação. Bioerosão baixa a moderada, encrustação baixa. Matriz suportada a alto grau de bioturbação.

Camada de canal de maré: biociasto suportada, valvas predominantemente com concavidade para baixo ou orientadas ao acaso. Bioturbação ausente, sem valvas articuladas. Índice de fragmentação alto, de abrasão moderado, de bioerosão moderado a alto, além de encrustação ausente.

Tabela 7. Classificações propostas segundo critério genético de concentrações fossilíferas marinho. 


\section{Tipos de concentrações esqueléticas}

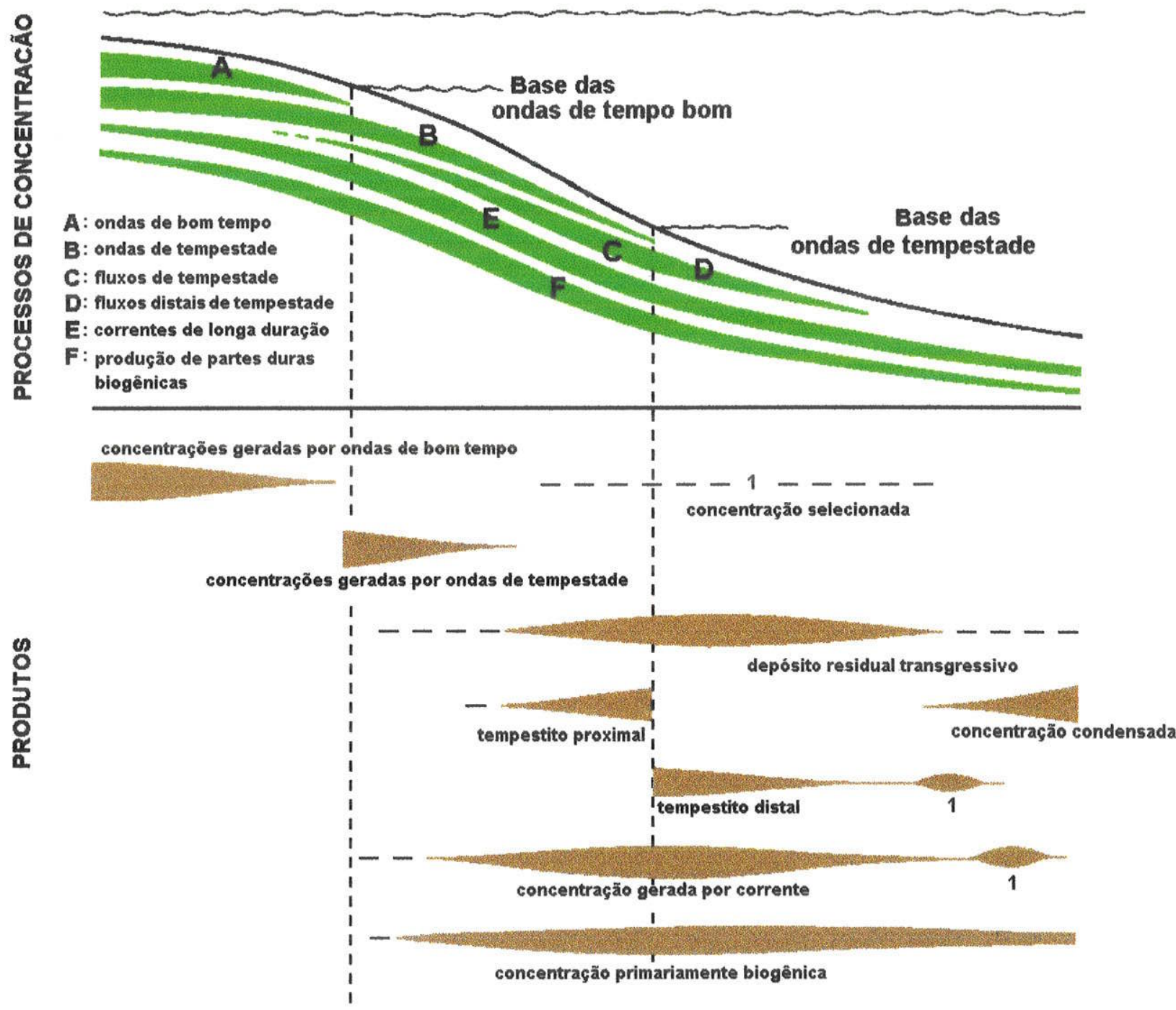

Figura 10. Distribuição dos diferentes tipos de concentrações fossilíferas no ambiente marinho ao longo de um gradiente de águas rasas/profundas, onde 1 corresponde a concentração selecionada. Segundo Fürsich e Oschmann (1993). 
De acordo com Fürsich e Oschmann (1993), os principais processos tafonômicos envolvidos na gênese das concentrações fossilíferas são:

a) ação de ondas (ondas de tempo bom e ondas de tempestade);

b) transporte (por fluxos de tempestade ou correntes de longa duração);

c) concentrações físicas (por seleção, retrabalhamento, transporte);

d) destruição física (i.e. quebra e abrasão);

e) ondas e correntes;

f) bioerosão/encrustação.

Segundo os autores, as concentrações fossiliferas formadas por ondas de bom tempo apresentam-se densamente empacotadas, suportadas por bioclastos. Em planta, os elementos esqueletéticos mostram orientação bimodal, pouca seleção e alta abrasão em alguns casos. Não ocorrem conchas incrustadas ou predadas, e a diversidade de espécies é baixa.

Ondas de tempestade formam concentrações esqueléticas diferentes das geradas por ondas de tempo bom, por apresentarem melhor qualidade de preservação. As concentrações têm base erosiva, seleção bimodal, além de orientação ao acaso, tanto em planta, quanto em seção. Geralmente, o retrabalhamento e subsequente soterramento final de bivalves, provavelmente ainda vivos ocorrem rapidamente e podem ser explicados pela ação de ondas de tempestade.

Assim como as concentrações geradas por ondas de tempestade, os tempestitos proximais, formados por fluxo de tempestade, apresentam as mesmas assinaturas tafonômicas, das geradas por ondas de tempestade, diferindo quanto à qualidade de preservação dos elementos esqueléticos. As conchas estão raramente quebradas, exibem baixo grau de abrasão e não mostram bioerosão nem incrustação. A boa qualidade de preservação das conchas indica deposição por correntes de curta duração, provavelmente fluxos de tempestade.

Os tempestitos proximais diferem dos tempestitos distais, pela espessura menor das camadas e bioclastos de tamanho maior e grau de seleção mais acentuado.

Nas concentrações formadas por correntes, os bioclastos apresentam-se orientados com a convexidade para cima, são pobremente selecionados e desarticulados, estando suportados por bioclastos. As conchas fragmentadas predominam sobre as 
inteiras, e a orientação em planta ocorre ao acaso. A maioria das conchas exibe abrasão intensa, algumas estão relativamente bem preservadas, porém outras possuem sinais de bioerosão.

As conchas acumuladas através de atividade biogênica resultam do hábito gregário ou a partir da alta densidade populacional de algumas espécies. Este tipo de concentração não é ,entretanto, muito comum. Ocorrem aí conchas articuladas fechadas de bivalves da epifauna, sugerindo pouco ou nenhum distúrbio após a morte dos organismos. Pode-se encontrar grande quantidade de bivalves preservados em posição de vida. Desta maneira, o índice de fragmentação é baixo, embora conchas incrustadas sejam comuns. 


\section{GÊNESE E CLASSIFICAÇÃo DAS CONCENTRAÇÕES FOSILIFFERAS DA REGIÃO DE TAMBAỨ}

\subsection{ASPECTOS GERAIS}

Uma das características comuns das concentrações fossiliferas, principalmente dos tempestitos proximais, é sua natureza complexa, envolvendo sucessão de eventos bioestratinômicos e sedimentológicos distintos. Kidwell e Aigner (1985) comentam que acumulações esqueléticas complexas podem conter mistura de bioclastos exibindo diferentes graus de preservação, e de bioclastos representativos de diferentes ambientes $e$ idades. A natureza complexa destas concentrações é evidenciada pela presença de superficies de descontinuidade, pavimentos de conchas ou mesmo de níveis contendo bioclastos com diferentes graus de empacotamento (Kidwell e Aigner, 1985). Da consulta a este trabalho fica dificil estabelecer qual é a escala de observação utilizada por Kidwell e Aigner (1985), uma vez que os autores não esclarecem se suas observações referem-se uma sucessão de sedimentos fossiliferos, num dado afloramento, ou uma concentração fossilifera, internamente complexa. Mais recentemente, porém, Simões e Kowalewski (1998a, b) demonstraram que, de fato, certas concentrações fossiliferas são internamente complexas e constituídas por diferentes subunidades reconhecidas com base na presença de bioclastos exibindo diferentes tipos e qualidade de preservação; no grau de empacotamento e distribuição dos bioclastos na matriz e na composição taxonômica $e$ ecológica (Simões, 1998; Simões e Kowalewski, 1998a,b).

O reconhecimento da natureza complexa de uma concentração fossilifera não é, entretanto, simples, pois depende de uma série de fatores, incluindo o grau de intemperismo dos sedimentos, a qualidade das exposições e o tipo de preservação dos fósseis. Além dos procedimentos de rotina, a coleta e a análise de uma concentração fossilifera internamente complexa envolve alguns procedimentos básicos de campo e laboratório, cujo não cumprimento compromete ou mesmo inviabiliza a análise final (Ghilardi, 1999).

Por diversas razões, a seguir comentadas, um estudo tafonômico empregando os mesmo procedimentos de Simões e Kowalewski $(1998 \mathrm{a}, \mathrm{b})$ não pode ser adotado. Em 
primeiro lugar, porque unidades microestratigráficas só foram identificadas megascopicamente nas concentrações A, B e C. O reconhecimento, não é, entretanto, desprovido de dúvidas, dado o alto grau de intemperismo da matriz sedimentar, e a impossibilidade de coleta de amostras orientadas de dimensões métricas para análise em seção polida. Em segundo lugar, apenas no caso da concentração $C$ é possível observar que o grau de empacotamento dos fósseis varia em direção ao topo. Mesmo assim, não se nota aqui a separação clara de unidades microestratigráficas sobrepostas (Fürsich e Oschmann, 1986; Simões et al., 1996), caracterizando uma concentração amalgamada. Deve-se ressaltar, entretanto, que o fato de uma concentração fossilifera não ser internamente complexa, não implica necessariamente que ela não tenha tido uma gênese complexa. Em terceiro lugar, e mais importante, algumas concentrações fossiliferas aqui estudadas (concentração A, B e C) representam tempestitos distais, que não apresentam, caracteristicamente, subunidades. De fato, tempestitos distais são comumente pouco espessos (Fürsich e Oschmann, 1986) e não amalgamados.

Pelas razões acima, os conjuntos de bioclastos estudados foram interpretados como formando concentrações fossiliferas isoladas no topo das camadas sedimentares. Se por um lado, os aspectos acima dificultam a reconstituição detalhada dos eventos de fundo e episódicos que foram, em parte, responsáveis pela sua gênese, por outro, o processo final de deposição pode ser determinado com precisão, constituindo importante dado para a comparação destas acumulações esqueléticas com outras melhor estudadas do Grupo Passa Dois, do Estado de São Paulo. Os dados obtidos permitem também atribuí-las a facies tafonômicas específicas, complementando os modelos de tafofacies disponíveis para o Grupo Passa Dois (Capítulo 8). 


\subsection{CONCENTRAÇÕES FOSSILÍFERAS A E B}

Descricão. As concentrações fossilíferas A e B, encontradas no afloramento número 1, localizado junto a antiga estrada secundária que liga Tambaú a Santa Cruz das Palmeiras $\left(21^{\circ} 39^{\prime} 58^{\prime \prime} \mathrm{S}\right.$ e $\left.47^{\circ} 14^{\prime} 86^{\prime} \mathrm{W}\right)$, serão tratadas conjuntamente por apresentarem características bioestratinômicas semelhantes (Tabela 8). Apesar de alguns parâmetros medidos, como por exemplo, a proporção de conchas articuladas fechadas serem um pouco diferentes, a história complexa de geração das duas concentrações fossilíferas parece ter sido semelhante.

A concentração fossilifera $\mathrm{A}$ possui espessura de aproximadamente $10 \mathrm{~cm}$ e contato basal brusco. Os bioclastos ocorrem dispersos em matriz arenosa, caoticamente dispostos em planta e paralelamente ao plano de acamamento em seção (Fig. 11). A análise dos bioclastos revelou que $47,6 \%$ encontram-se arranjados com a convexidade voltada para baixo (Fig. 12), 40,9\% com a convexidade para cima e apenas $11,5 \%$ estão dispostos de modo imbricado ao plano de acamamento. A maioria dos bioclastos $(82,05 \%)$ está desarticulada, porém conchas articuladas fechadas $(10,26 \%)$ e articuladas abertas (7,69\%) também podem ser encontradas (Fig. 13). Vale notar que todos os bivalves articulados, fechados e abertos, são atribuídos à Pinzonella neotropica. Dentre as conchas desarticuladas, $51,74 \%$ das valvas são direitas e $48,20 \%$ esquerdas. A maioria dos bioclastos não está fragmentada $(65,79 \%)$, porém conchas fragmentadas $(34,21 \%)$ podem ser encontradas. Note-se, contudo, que parte da fragmentação pode ter ocorrido durante a coleta e preparação. 


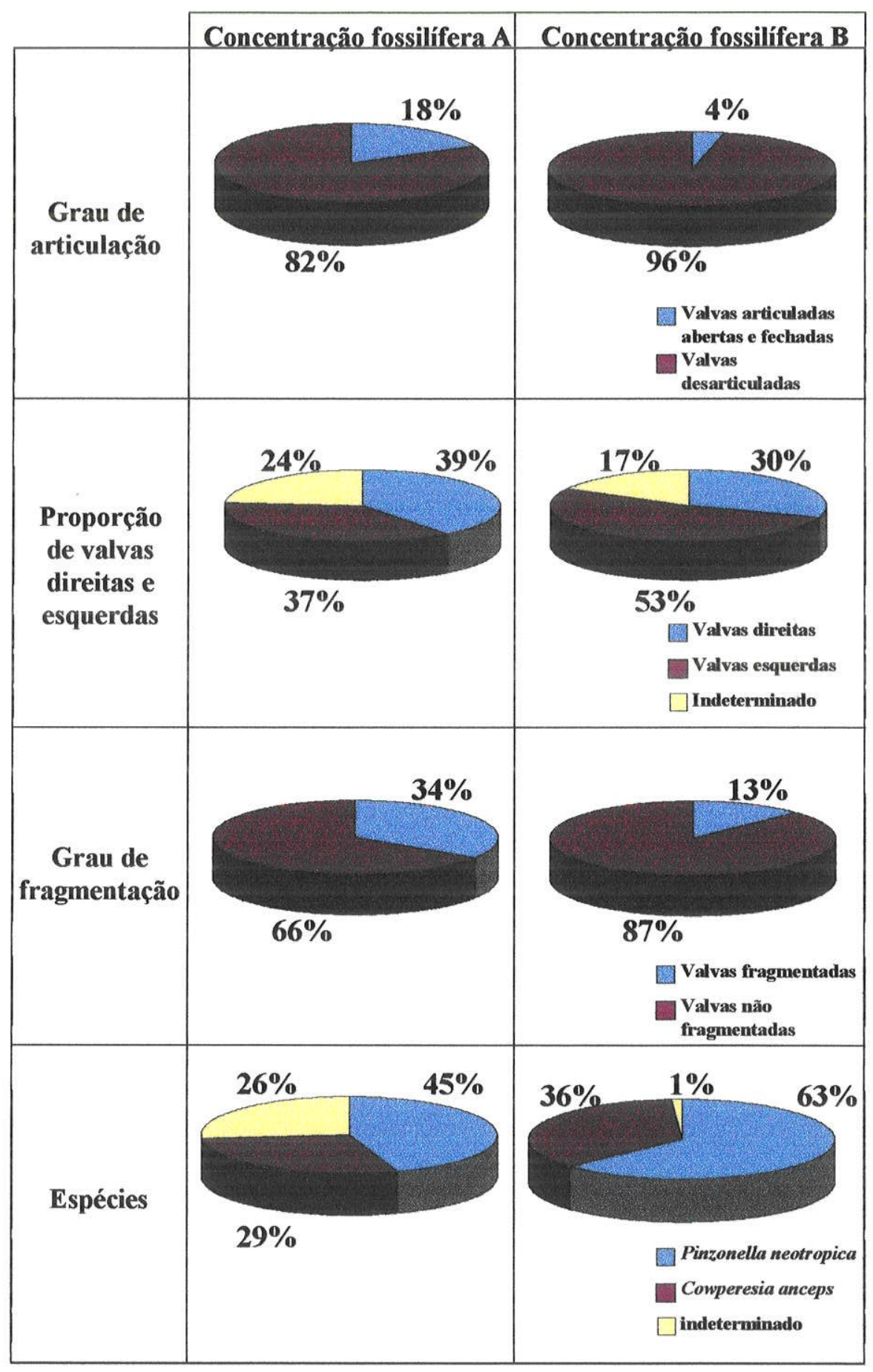

Tabela 8. Comparação entre as características das concentrações fossilíferas 1 e 2. 


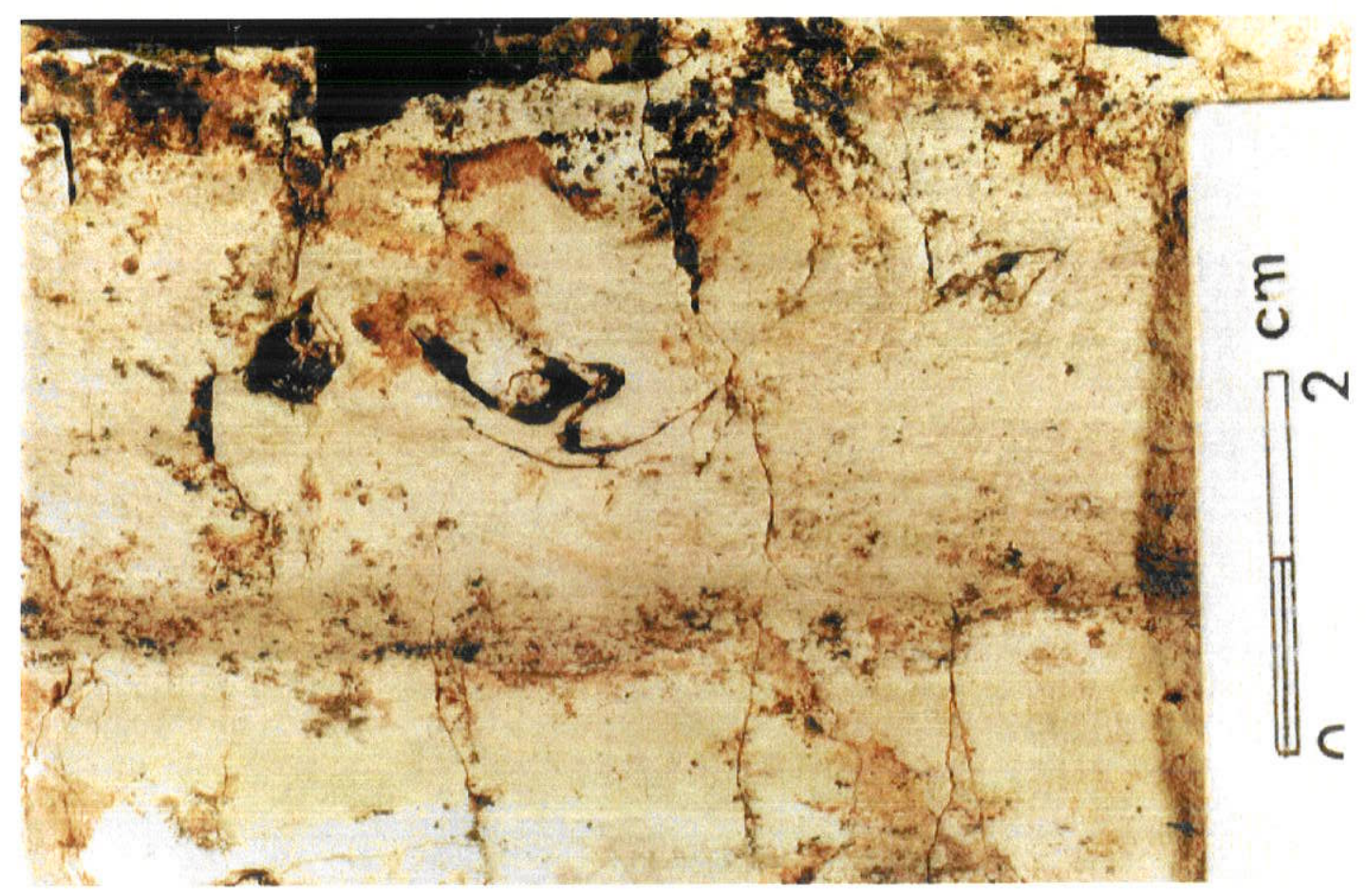

Figura 11. Afloramento 1: Arenito fino com moldes de bivalves dispostos paralelamente à estratificação (concentração A).

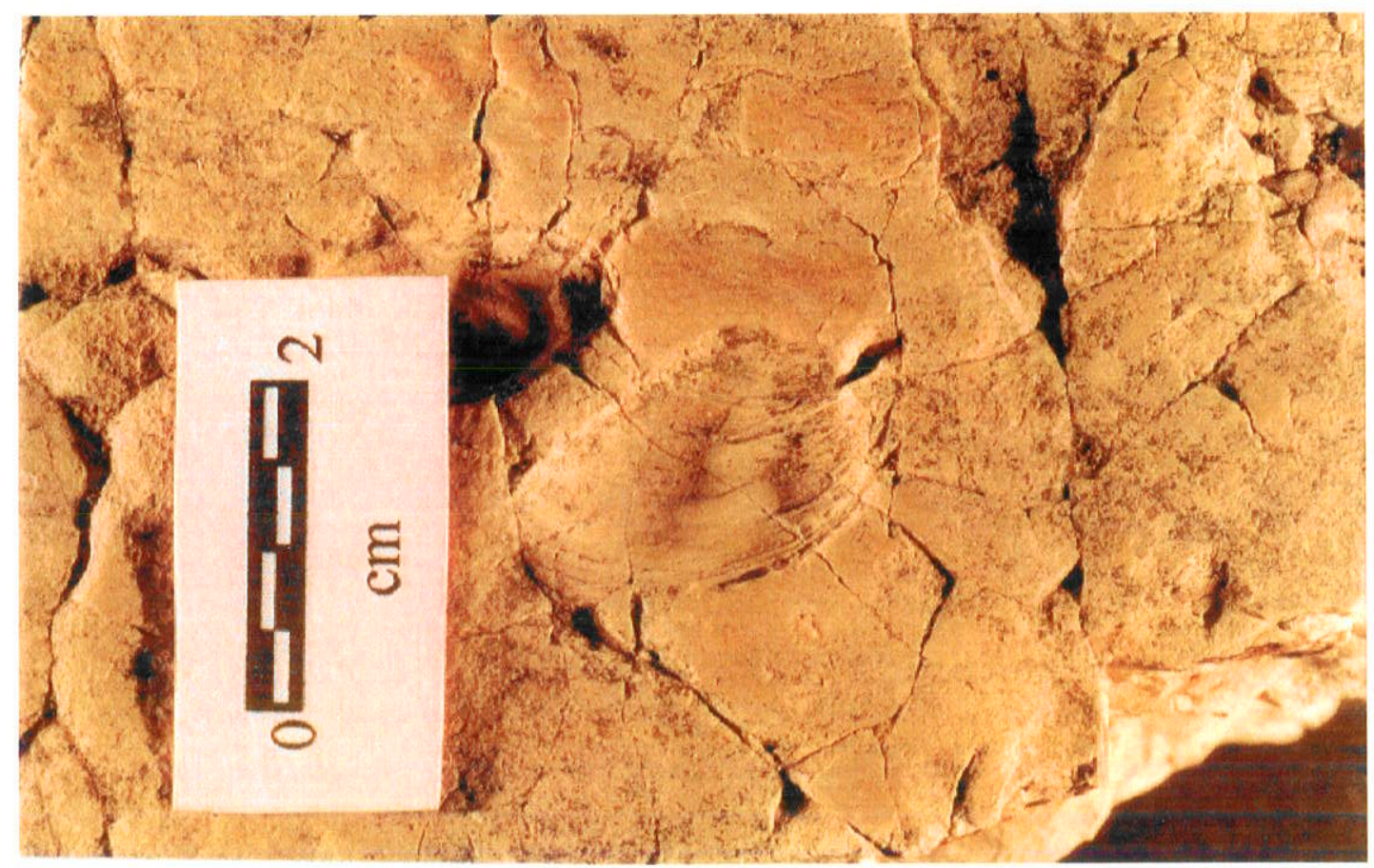

Figura 12. Afloramento 1: Bivalve com convexidade voltada para baixo (molde) em arenito fino; notar linhas de crescimento bem marcadas (vista em planta; concentração A). 


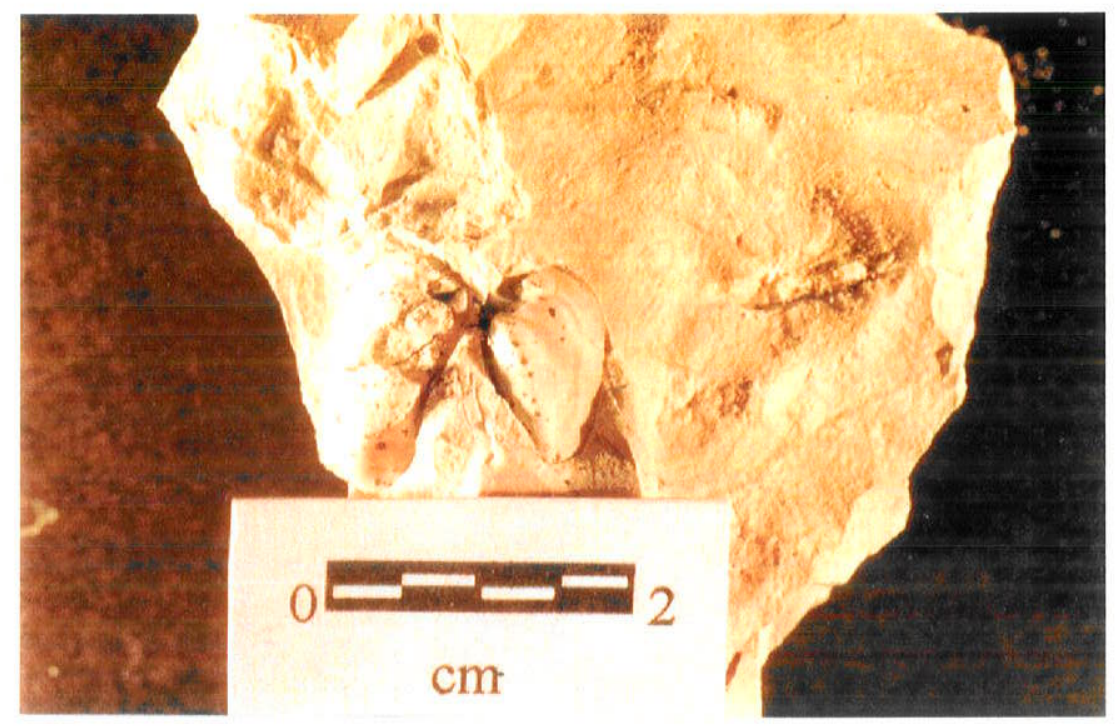

Figura 13. Afloramento 1: Molde interno de Pinzonella neotropica com as duas valvas articuladas, abertas em matriz síltica. Vista em planta (concentração B).

Nesta concentração fossilífera são encontrados apenas bivalves atribuídos a Pinzonella neotropica $(44,74 \%)$ e Cowperesia anceps $(28,95 \%)$, elementos que caracterizam a assembléia de Pinzonella neotropica (Reed). Dentre os bioclastos coletados, 26,31\% não puderam ser identificados. Cowperesia anceps possui concha curta, com sinus palial raso, porém bem definido (Mendes, 1952; Runnegar e Newell, 1971), o que sugere hábito de vida escavador intermediário (Simões et al., 1996a). De acordo com Simões et al. (1996a), Cowperesia anceps possui músculo retrator pedial bem desenvolvido, indicado pela ocorrência de impressão muscular grande e fortemente marcada. Estas feições sugerem hábito escavador ativo. Esta forma possui também ornamentação proeminente, constituída de linhas de crescimento bem demarcadas. A concha pequena, comprimida e delgada de Cowperesia anceps indica que a espécie escavava rapidamente o sedimento muito fino, mole, inconsolidado e fluidificado (Stanley, 1970). A concha de Pinzonella neotropica sugere hábito escavador raso (Simões et al., 1996a). Conforme mencionado anteriormente, foram encontradas conchas de Pinzonella neotropica articuladas fechadas. Animais desta espécie, com as valvas articuladas ainda não eram conhecidos na literatura. Pôde-se também notar que as valvas de Pinzonella neotropica têm tamanhos diferentes, caracterizando a concha como inequivalve. 
O fato de a valva esquerda de Pinzonella neotropica ser cerca de 1,5 vezes maior que a valva direita (Ghilardi, 1999), tem importante implicação no processo de seleção associado a gênese da concentração, debatido mais adiante. As distribuições das classes de tamanho de Pinzonella neotropica e Cowperesia anceps nas concentrações fossilíferas A e B são mostradas nas Figuras 14 e 15, respectivamente.

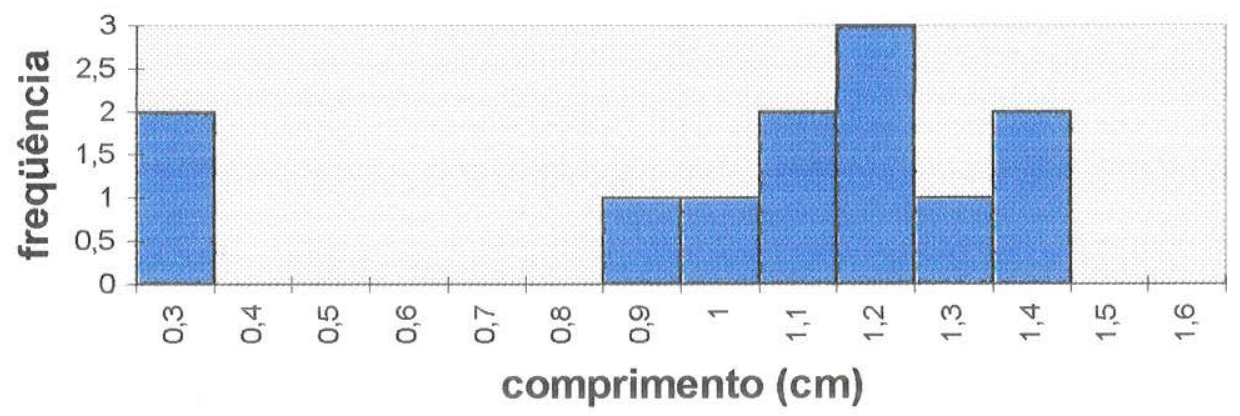

A

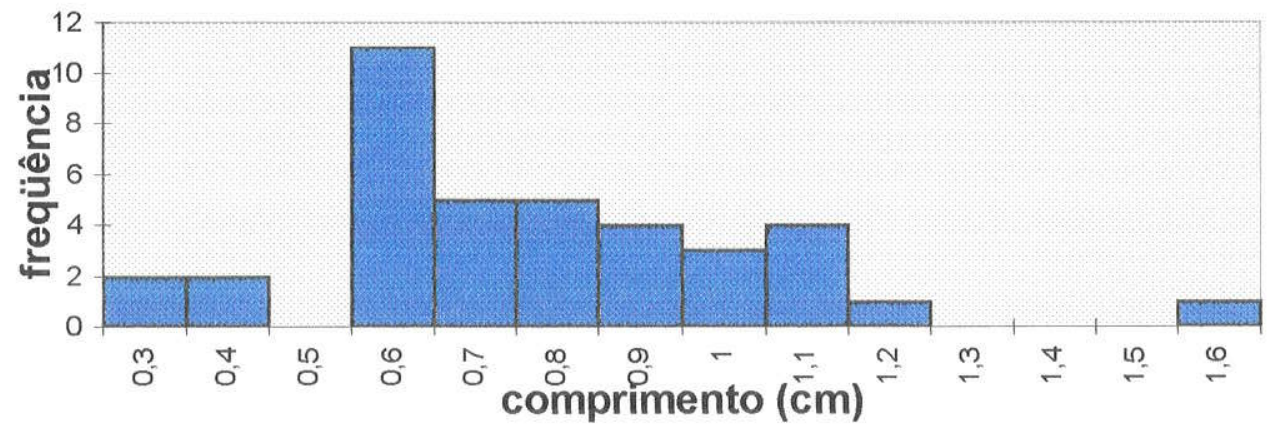

$\mathbf{B}$

Figura 14. Afloramento 1: distribuição de classes de tamanho de Pinzonella neotropica (A) concentração fossilífera A; (B) Concentração fossilífera B. 


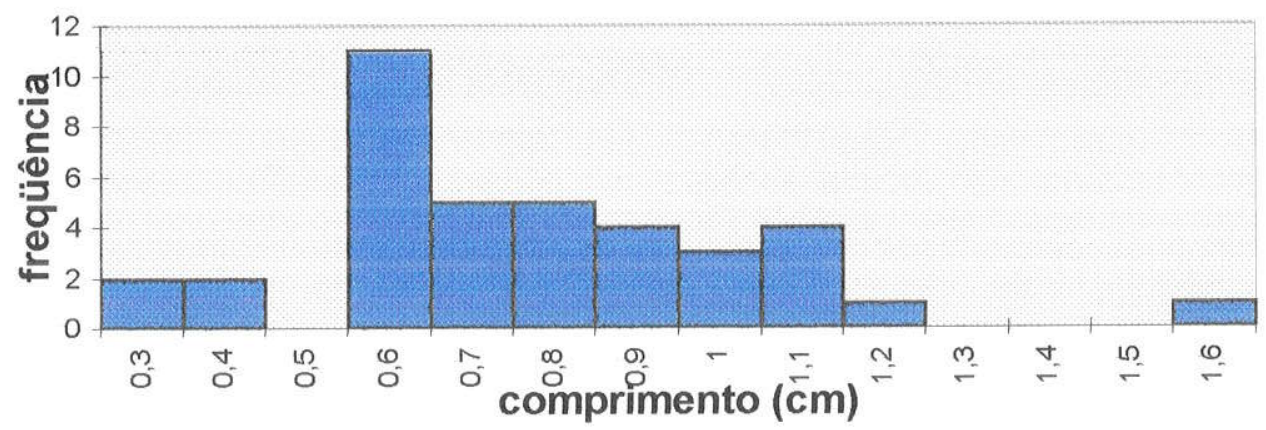

A

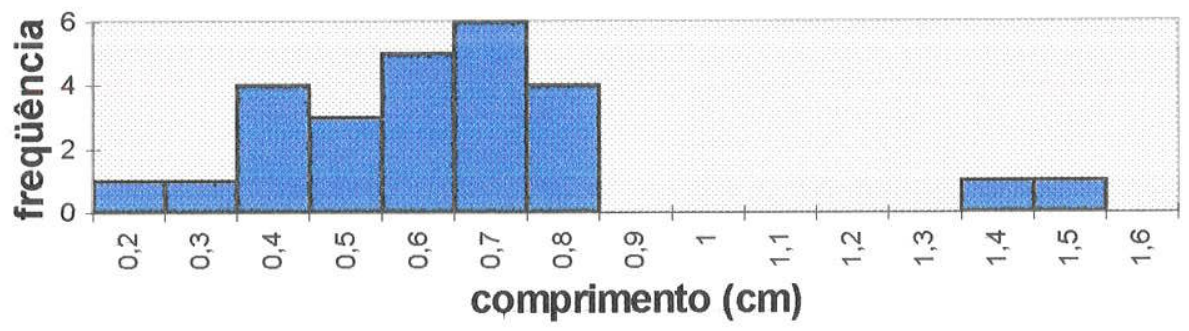

B

Figura 15. Distribuição das classes de tamanho de Cowpereia anceps nas concentrações fossilíferas A e B. Explicação: $A=$ concentração fossilífera $A, B=$ concentração fossilífera $B$.

A espessura da concentração fossilífera B é de aproximadamente $10 \mathrm{~cm}$, sendo seu contato basal brusco e erosivo. Assim como a concentração fossilífera A, os bioclastos nesta acumulação encontram-se arranjados de maneira caótica na matriz arenosa, porém, quando analisados em planta, em terras do Sítio São Joaquim, estas conchas apresentam-se arranjadas preferencialmente com a concavidade voltada para baixo. A grande maioria das valvas apresenta-se desarticulada $(96,4 \%)$; conchas 
articuladas fechadas $(0,7 \%)$ e abertas $(2,9 \%)$ também são raramente encontradas. A proporção entre valvas direitas e esquerdas é semelhante. Embora $11,60 \%$ das conchas apresentem algum grau de fragmentação, a grande maioria $(88,4 \%)$ está íntegra. Do mesmo modo que na concentração fossilifera $\mathrm{A}$, parte da fragmentação dos bioclastos pode estar relacionada à coleta e preparação dos espécimes.

Espécies identificadas nesta concentração fossilifera incluem: Pinzonella neotropica $(63,38 \%)$ e Cowperesia anceps $(35,91 \%)$; porém $16,90 \%$ do total não podem ser determinada. Conforme já mencionado, Cowperesia anceps apresenta feições características de um bivalve escavador ativo, intermediário. Já Pinzonella neotropica é interpretada como de hábito escavador raso.

Discussão. A análise da biofábrica (e.g., tipo de matriz, grau de empacotamento dos bioclastos, gradação, seleção) e das assinaturas tafonômicas permite investigar a natureza complexa de concentrações fossilíferas. Porém, é importante notar que as assinaturas tafonômicas fornecem informações a respeito dos processos que atuaram no ambiente de origem dos bioclastos, processos estes que corresponciem ao dia-a-dia (processos tafonômicos de fundo). Por outro lado, a natureza da matriz (e.g., alto grau de empacotamento, gradação) é determinada por processos finais de concentração (Davies et al., 1989; Fürsich e Oschmann, 1993), que exercem pouca influência sobre as assinaturas tafonômicas (processos episódicos).

Processos tafonômicos de fundo correspondem processos que atuam durante um longo período de tempo e de natureza intrinsicamente destrutiva (Davies et al., 1989). Os fatores que regulam a intensidade dos processos de fundo podem ser: a) taxa de sedimentação; b) energia do meio; e c) bioturbação (Speyer e Brett, 1991).

Processos tafonômicos episódicos ocorrem durante um curto período de tempo do ponto de vista geológico (variando de horas a dias), associados a eventos catastróficos, interrompendo os processos de fundo e gerando assim um espectro variado de depósitos fossilíferos marinhos ao longo do perfil águas rasas-águas profundas (Speyer e Brett, 1991).

A análise da biofábrica das concentrações fossilíferas A e B aponta-nos que, em planta, os bioclastos apresentam-se distribuídos de maneira caótica na matriz, com a 
convexidade voltada para cima ou para baixo, oblíquos ou perpendiculares. Biofábricas caracterizadas pelo arranjo caótico dos bioclastos na matriz refletem a ação de correntes turbulentas junto ao substrato (Kelling e Willians, 1967). Em ambas concentrações, há um predomínio de conchas desarticuladas $(82,05 \%$ e $96,4 \%$, respectivamente), com a convexidade voltada para baixo.

Convexidade voltada para cima corresponde ao arranjo hidrodinamicamente estável da concha de um bivalve, resultado de prolongada exposição dos bioclastos à atuação de correntes (Clifton e Boggs, 1970; Futterer, 1982; Oliveira e Wood, 1997). A presença de valvas arranjadas com a concavidade voltada para cima, sugere que a energia do meio, antes do soterramento, foi baixa (Brett e Baird, 1986), não suficiente para orientar as valvas em sua posição mais estável. O tempo de exposição destes bioclastos na interface água/sedimento parece não ter sido muito grande, tendo em vista a predominância de valvas em posição não estável. A mistura de conchas desarticuladas com convexidade voltada para cima e para baixo e conchas articuladas abertas e fechadas é um indicador de que os episódios de retrabalhamento foram rapidamente sucedidos por eventos de sedimentação episódica (Allmon, 1985; Brett e Baird, 1986; Torello e Simões, 1994).

De uma maneira geral, concentrações fossilíferas geradas por tempestades tendem a apresentar boa qualidade de preservação dos bioclastos, contendo mistura de valvas desarticuladas e articuladas (Aigner, 1985; Fürsich e Kirkland, 1986; Fürsich e Oschmann, 1986, 1993; Simões e Rocha-Campos, 1992; Torello e Simões, 1993b, 1994). Este é o padrão encontrado nas concentrações fossilíferas A e B, nas quais respectivamente $82,05 \%$ e $96,4 \%$ das conchas estão desarticuladas, porém existem conchas articuladas fechadas $(10,26 \%$ e $0,7 \%)$ e conchas articuladas abertas $(7,69 \%$ e $2,9 \%$ ). As conchas desarticuladas, pertencentes a apenas uma ou duas classe de tamanho, apresentam desgaste diferenciado das linhas de crescimento, algumas exibindo intensa abrasão e outras apresentando boa qualidade de preservação. Esta diferença indica provável mistura temporal de restos esqueléticos, tendo certos bioclastos experimentado prolongado retrabalhamento.

Nas duas concentrações, conchas articuladas fechadas correspondem todas a Pinzonella neotropica. Isto significa que estes bivalves não sofreram acentuado 
transporte lateral, já que as conchas articuladas fechadas e abertas são elementos tipicamente preservados em fundos sujeitos a aumento brusco na taxa de sedimentação e soterramento catastrófico (Allmon, 1985; Brett e Seilacher, 1991; Torello e Simões, 1993a). Este fato é facilmente explicável, quando se analisa a sequuência de desarticulação de conchas.

Desarticulação consiste na desintegração do endo ou exoesqueleto ao longo de suas juntas naturais, por deterioração bacteriana dos tecidos de conexão. Quando os bivalves estão vivos, as valvas mantém-se fechadas graças à contração dos músculos adutores. Com a morte do organismo e posterior necrólise dos tecidos de conexão, a tendência é de abertura das valvas, podendo estas serem preservada unidas ("butterflied") apenas pelo ligamento, que é uma estrutura bastante frágil. A movimentação lateral e/ou deslocamento da concha, por ação de correntes e ondas, causa a desarticulação. Desta maneira, a presença de conchas articuladas fechadas e/ou articuladas abertas indica pouco transporte, baixo retrabalhamento e curto ou nenhum período de exposição destas conchas na interface água/sedimento. Tal fato explica-se pela rapidez com que a desarticulação das valvas ocorre (em até poucas semanas), principalmente em ambiente bem oxigenado (Schafer, 1972). Conchas com estas características não devem ter permanecido por um grande período na interface água/sedimento, nem foram transportadas lateralmente por uma distância muito grande, tendo sido exumadas, reorientadas e rapidamente misturadas com as já presentes no substrato, provavelmente devido à ação de eventos de alta energia associados a tempestades. Segundo Fürsich e Oschmann (1993), associação de conchas fechadas e conchas articuladas abertas representam soterramento rápido de bivalves ainda vivos, normalmente através de ondas de tempestade (Fürsich e Oschmann, 1993).

No caso das concentrações fossiliferas $\mathrm{A}$ e $\mathrm{B}$, os bioclastos encontram-se dispersos em matriz arenosa. Esta situação, sugere ausência de seleção granulométrica da matriz siliciclástica (Kidwell e Holland, 1991), além de curto período de tempo de atuação dos processos de erosão, retrabalhamento e seleção, durante evento episódico.

Várias características citadas acima, tais como, a presença de conchas articuladas fechadas, proporção aproximadamente igual de valvas esquerdas e direitas, bioclastos fracamente empacotados na matriz, dispostos de maneira oblíqua ao plano de 
acamamento, além de natureza predominantemente maciça do arenito, sugerem rápida deposição sedimentar.

Com relação a esta última característica, é provável que a taxa de sedimentação, tenha diminuído bruscamente, pois, neste caso, os bioclastos deveriam apresentar-se densamente empacotados.

Em resumo, portanto, é altamente provável que as concentrações fossiliferas A e $B$ tenham sido geradas através de eventos de alta energia, possivelmente tempestades. As concentrações fossilíferas foram provavelmente depositadas abaixo da base das ondas de tempestade, pois apresentam, pouca proporção de conchas fragmentadas, alto índice de conchas articuladas e alta proporção de matriz. As diversas classes de tamanho dos bioclastos refletem diversos episódios de morte natural das populações de bivalves (Walker e Bambach, 1971; Brenchley e Harper, 1998). Desta maneira, raros eventos episódicos mais energéticos seriam capazes de causar erosão do substrato mesmo abaixo da base de ondas de tempestade (Brett e Baird, 1997) e exumar os animais mortos desarticulando-os (Brett e Baird, 1986; Kondo, 1998). De acordo com a classificação de Fürsich e Oschmann (1993), as concentrações fossiliferas A e B são parautóctones ou alóctones, representando tempestitos distais.

\subsection{CONCENTRAÇÃO FOSSILÍFERA C}

Descrição. A concentração fossilífera 3, localiza-se em terras pertencentes ao Sítio São João do Capão Redondo, na estrada secundária que liga Tambaú a Santa Rosa do Viterbo, na região de Tambaú (2139'36'S e 47 15'32'W). A concentração fossilífera C possui espessura variando de 2 a $11 \mathrm{~cm}$ e estende-se lateralmente por, pelo menos 8 metros. Seu contato basal é brusco e erosivo, e o contato superior ondulado e brusco. Os bioclastos variam desde densamente empacotados até dispersos em matriz argilosa. $O$ grau de empacotamento geralmente aumenta em direção ao topo da concentração fossilifera (Fig. 16). Em locais onde os bioclastos estão densamente empacotados, é notável a presença de conchas aninhadas (Fig. 17) e empilhadas. Os fósseis, variando em tamanho de $<1 \mathrm{~cm}$ até $8 \mathrm{~cm}$, apresentam-se arranjados caoticamente na matriz. A maioria 
dos bioclastos está desarticulada e fragmentada, porém conchas articuladas abertas e fechadas ocorrem esporadicamente. São encontradas conchas de Naiadopsis lamellosus preservadas em posição de vida no topo da concentração. Deritre os bioclastos presentes, podem ser notadas valvas apresentando intensa abrasão, assim como valvas com linhas de crescimento bem preservadas. Não são encontrados sinais de bioerosão ou incrustação. Bivalves presentes na concentração $\mathrm{C}$ incluem: Pinzonella neotropica, Cowperesia anceps, Holdhausiella elongata, Jacquesia brasiliensis e Naiadopsis lamellosus. Pinzonella neotropica e Jacquesia brasiliensis são interpretados como escavadores rasos, Cowperesia anceps, escavador intermediário e Naiadopsis lamellosus, semi-infauna bissada.

Jacquesia brasiliensis possui características típicas de um megadesmídio escavador raso, com concha posteriomente alongada, robusta, sem descontinuidade comissural (Runnegar, 1974), além de linha palial íntegra (Simões et al., 1996a). A presença de músculos adutores subguais e músculos retratores pediais grandes, sugere a existência de um pé desenvolvido e consequentemente um hábito escavador ativo (Simões et al., 1996a). A concha de Jacquesia brasiliensis é fortemente inflada, o que para Stanley (1970) indica um hábito de vida escavador lento, portanto é interpretada como uma forma escavadora rasa.

Holdhausiella elongata possui concha pequena a média, posteriormente expandida, em alguns casos possuindo expansão anterior no final da charneira. Como a musculatura ainda não é completamente conhecida, o provável modo de vida desta espécie só pode ser inferido, levando-se em conta a morfologia externa da concha. Tratase, de uma forma escavadora rasa, como evidencia a ausência de uma abertura sifonal bem marcada.

Quanto a Naiadopsis lamellosus, esta é a única espécie presente nesta concentração fossilífera que não é interpretada como pertencente à infauna, sendo interpretada como sendo da semi-infauna bissada (Ghilardi et al., 1995; Ghilardi, 1999). Segundo Stanley $(1970,1972)$ uma espécie da semi infauna apresenta as seguintes características, que podem ser encontradas em Naiadopsis lamellosus:

a)conchas com a porção anterior pouco desenvolvida;

b)obesidade máxima situada no ponto médio do eixo dorso-ventral da concha; 
c)impressão bem definida do músculo retrator bissal, acima do adutor anterior.

Discussão. $\mathrm{O}$ contato brusco e erosivo da concentração sobre o arenito subjacente indica ter havido retrabalhamento do substrato antes da deposição final dos bioclastos.

A biofábrica caracteriza-se pelo arranjo caótico dos bioclastos na matriz, refletindo a ação de correntes turbulentas, junto ao substrato (Kelling e Willians, 1967), durante eventos de tempestade (Kidwell e Bosence, 1991). De fato, a presença de conchas aninhadas ou empilhadas, com a convexidade voltada para cima ou para baixo, ou ainda imbricadas, é registrada em concentrações fossilíferas geradas por tempestades (Banerjee e Kidwell, 1991). Esta feição resulta da interferência entre os bioclastos durante o transporte (Kidwell e Bosence, 1991) e da sua rápida deposição, associada a fluxos de tempestade (Fürsich e Oschmann, 1986).

Concentrações esqueléticas geradas por este processo tendem a apresentar boa qualidade de preservação dos bioclastos, contendo freqüentemente mistura de conchas com valvas desarticuladas e valvas conjugadas (Aigner, 1985; Fürsich e Kirkland, 1986; Fürsich e Oschmann, 1986, 1993; Simões e Rocha-Campos, 1992; Torello e Simões, 1993a, 1994). A maioria das conchas está desarticulada, porém conchas articuladas fechadas e, em menor número, articuladas abertas também são encontradas.

A distribuição tridimensional dos bioclastos na matriz parece também confirmar essa interpretação (Kelling e Willians, 1967; Kidwell e Bosence, 1991). De fato, a presença de conchas aninhadas ou empilhadas, com a convexidade voltada para cima ou para baixo, ou imbricadas, é comum em concentrações fossilíferas geradas por tempestades (Banerjee e Kidwell, 1991).

Concentrações esqueléticas geradas por tempestades tendem a apresentar boa qualidade de preservação dos bioclastos, contendo freqüentemente mistura de conchas com valvas desarticuladas e valvas conjugadas (Aigner, 1985; Fürsich e Kirkland, 1986; Fürsich e Oschmann, 1986, 1993; Simões e Rocha-Campos, 1992; Torello e Simões, 


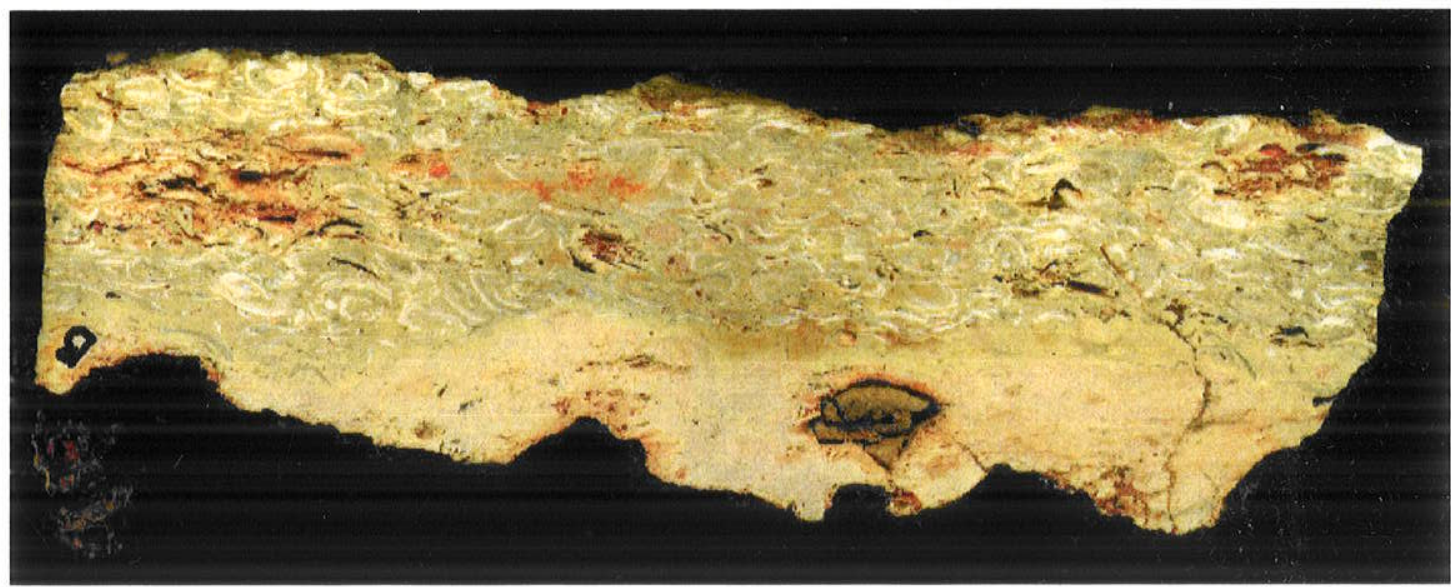

Figura 16. Afloramento 2: Concentração fossilífera C. Notar aumento do grau de empacotamento dos bioclastos em direção ao topo. Espessura da amostra: $4,5 \mathrm{~cm}$.

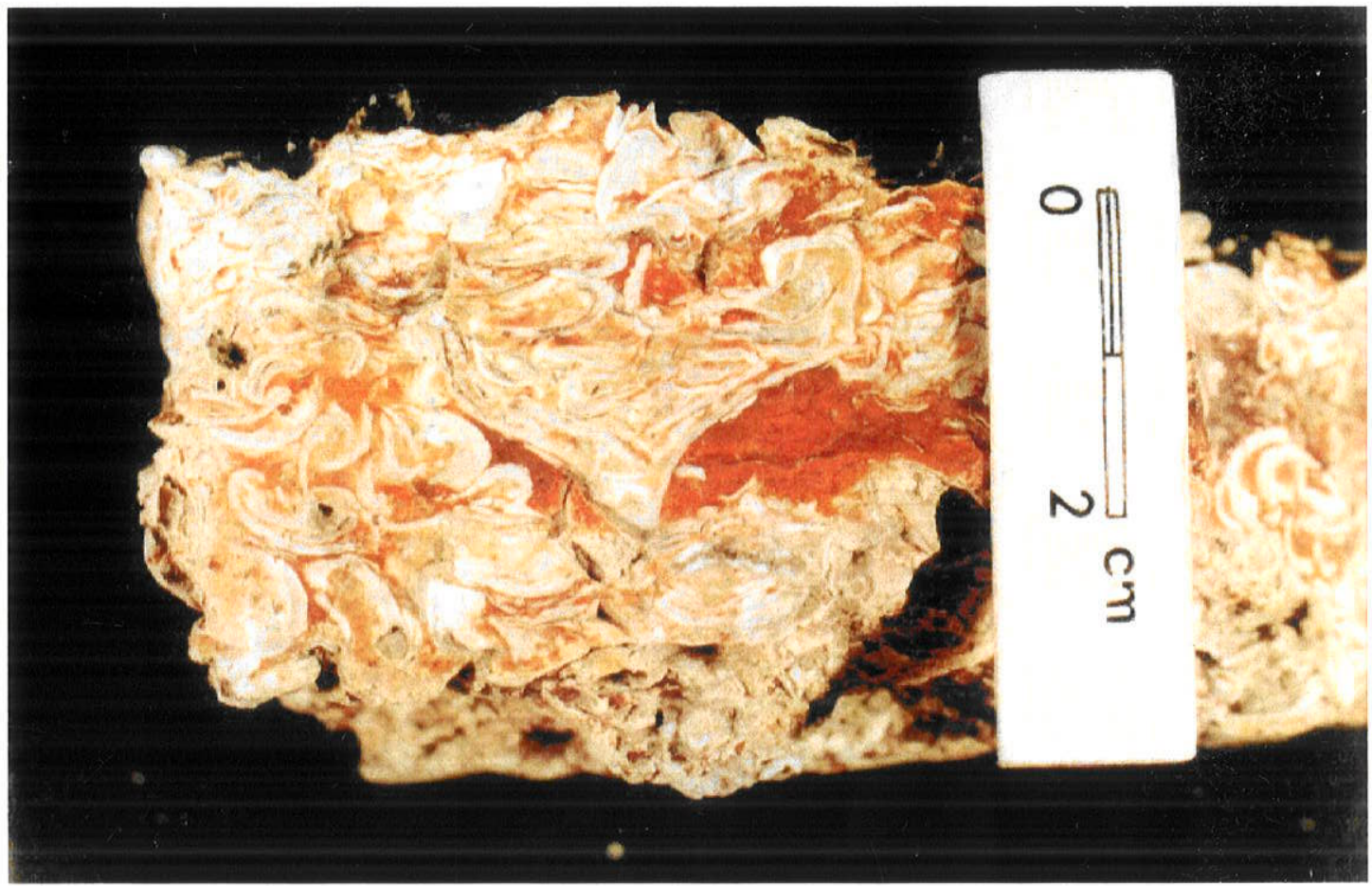

Figura 17. Afloramento 2: Concentração fossilífera C: presença de conchas aninhadas (em corte). 
1993a, 1994). Contrariamente, na concentração em estudo, as conchas encontram-se extremamente fragmentadas, porém conchas inteiras também são encontradas. A maioria das conchas está desarticulada, mas conchas articuladas fechadas e em menor número articuladas abertas também são encontradas.

A grande quantidade de valvas desarticuladas e fragmentadas indica acentuado retrabalhamento destes bioclastos em locais de águas rasas, antes do soterramento final por eventos de tempestade (Fürsich e Oschmann, 1993). Estudos demonstram também que os bioclastos podem sofrer retrabalhamento por ondas, em ambiente intermaré. Porém, é importante destacar, não ter ainda sido registrado sedimentos tipicamente praiais na Formação Corumbataí ou depósitos indicativos de acentuada atuação de ondas (Rohn, 1994).

A presença de conchas articuladas fechadas é atribuível à recolonização de substrato composto por bioclastos já retrabalhados, alguns fragmentados, depositados através de um evento de tempestade anterior, por elementos da epifauna e no caso da semi-infauna bissada.

A concentração fossilífera $\mathrm{C}$ inclui conchas de Naiadopsis lamellosus preservadas em posição de vida. A presença de elementos da semi-infauna bissada preservada in situ evidencia mortalidade em massa em conseqüência de soterramento rápido (Miller et al., 1988). O soterramento de elementos como Naiadopsis lamellosus ocorreu no topo da concentração fossilífera por camada de sedimento fino (argila) pouco espessa, depositada durante evento de tempestade.

De acordo com Miller et al. (1988), concentrações fossilíferas depositadas em ambiente marinho variam em suas características de acordo com a profundidade (Miller, 1986; Brett et al., 1986; Parsons et al., 1988).

Com o aumento da profundidade, as concentrações fossiliferas depositadas apresentam complexidade interna mais simples e são recobertas por camadas de sedimento fino. Em ambientes ainda mais distais, as concentrações tornam-se mais finas e separadas por camadas de sedimentos finos, além de apresentarem bioturbação (Miller et $a l ., 1988)$.

Segundo Miller et al. (1988), mudanças no padrão das concentrações fossilíferas de acordo com a profundidade, refletem dois processos relacionados a tempestade que 
afetam o fundo oceânico, de grande impacto sobre a fauna bentônica. Estes dois processos são denominados por Miller et al., 1988 como: seleção e cobertura lamosa. A Figura 18A ilustra a ocorrência destes dois processos, além do padrão geral de variação da espessura da cobertura lamosa, de acordo com a profundidade (Fig. 18B).

A profundidade não controla apenas a espessura da camada de lama e a freqüência de seleção e cobertura lamosa, mas determina também a freqüência da ocorrência de depósitos gerados por tempestades e probabilidade de preservação destes (Fig 19). Acima da base média das ondas de tempestade, o registro é freqüentemente destruído pelo impacto da tempestade, com predominância de processos erosivos e de seleção. Abaixo desse nível, os depósitos fossilíferos apresentam alta probabilidade de preservação, porém, somente as tempestades mais severas permanecem registradas. $\mathrm{Na}$ Figura 20, os depósitos de seleção e de cobertura lamosa são mostrados esquematicamente, de acordo com sua posição batimétrica (Miller et al.,1988).

Após a formação das concentrações fossilíferas as condições da água voltam a ser calmas, propiciando redeposição do sedimento suspenso sob as concentrações depositadas, entre profundidades correspondentes à base das ondas de tempestade e ondas normais. Entretanto, esta camada fina de sedimento pode ser rapidamente removida e erodida por tempestades menos intensas subsequentes, deixando o pavimento de conchas susceptível à colonização pela epifauna ou semi-infauna (Pilkey et al., 1978; Aigner, 1982; Nelson, 1982). Este retrabalhamento ocorre principalmente em ambiente proximal, onde as concentrações fossiliferas preservam-se somente quando há um soterramento rápido por sedimentos arenosos (Norris, 1986). (Fig. 21) 


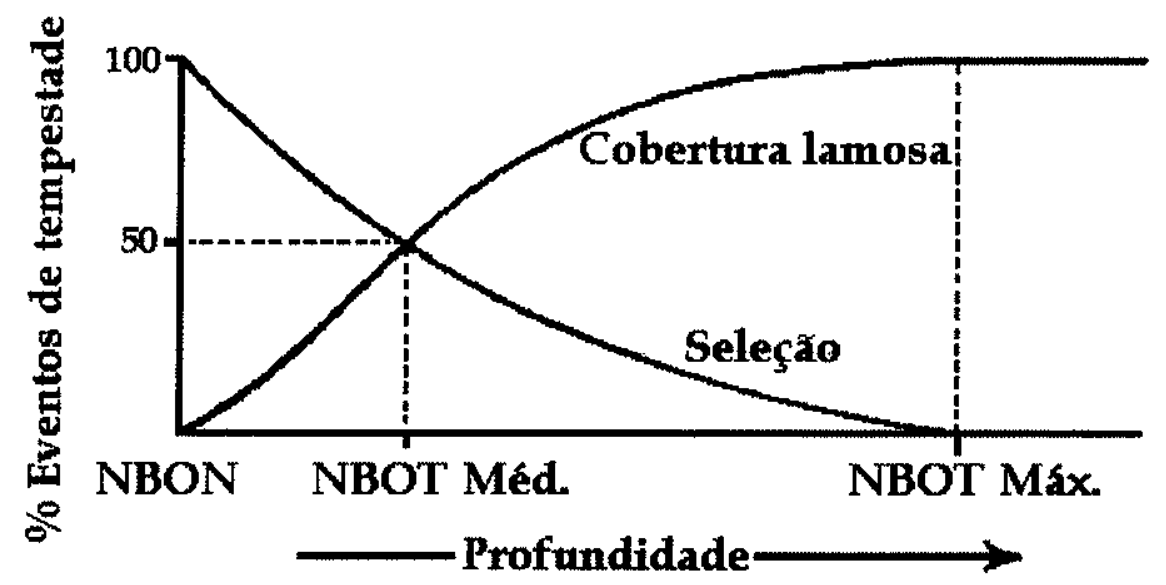

A

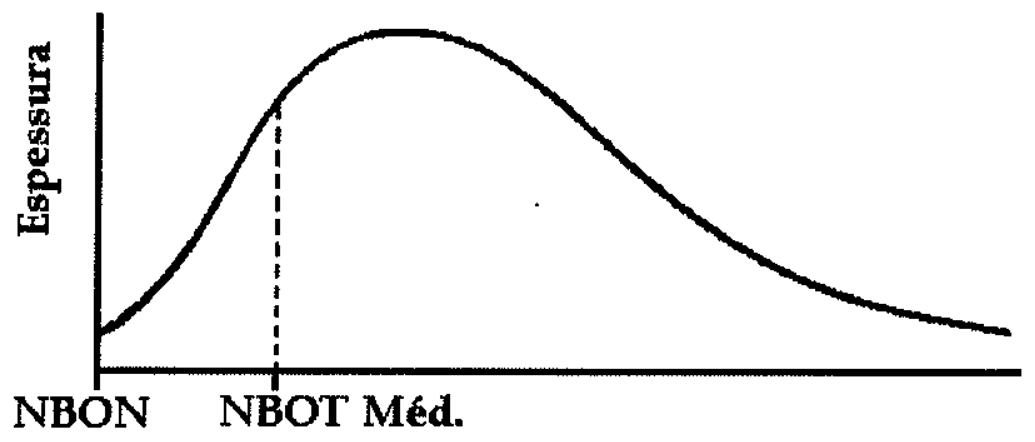

$\longrightarrow$ Profundidade $\longrightarrow$

B

Figura 18. A) Frequiência de ocorrência de seleção e de cobertura lamosa de acordo com a profundidade. B) Padrão geral de variação da espessura da cobertura lamosa de acordo com a profundidade. Explicação: NBON: base das ondas normais; NBOT Méd.: base média das ondas de tempestade; NBOT Máx.: base máxima das ondas de tempestade (modificado de Miller et al., 1988) 


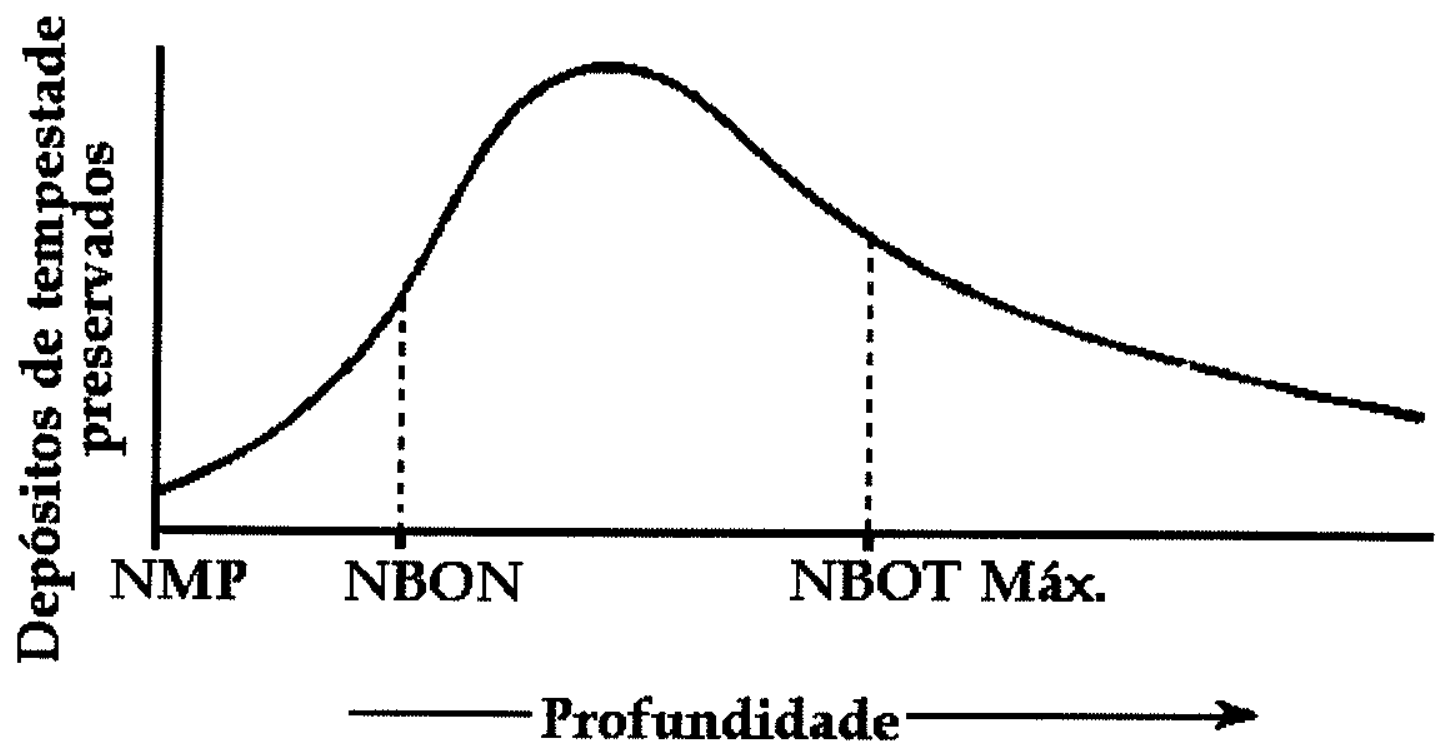

Figura 19. Frequência esperada de preservação de depósitos de tempestade de acordo com a profundidade. Explicação: NMP: nível principal do mar; NBON: base das ondas normais; NBOT: base das ondas de tempestade (modificado de Miller et al., 1988). 


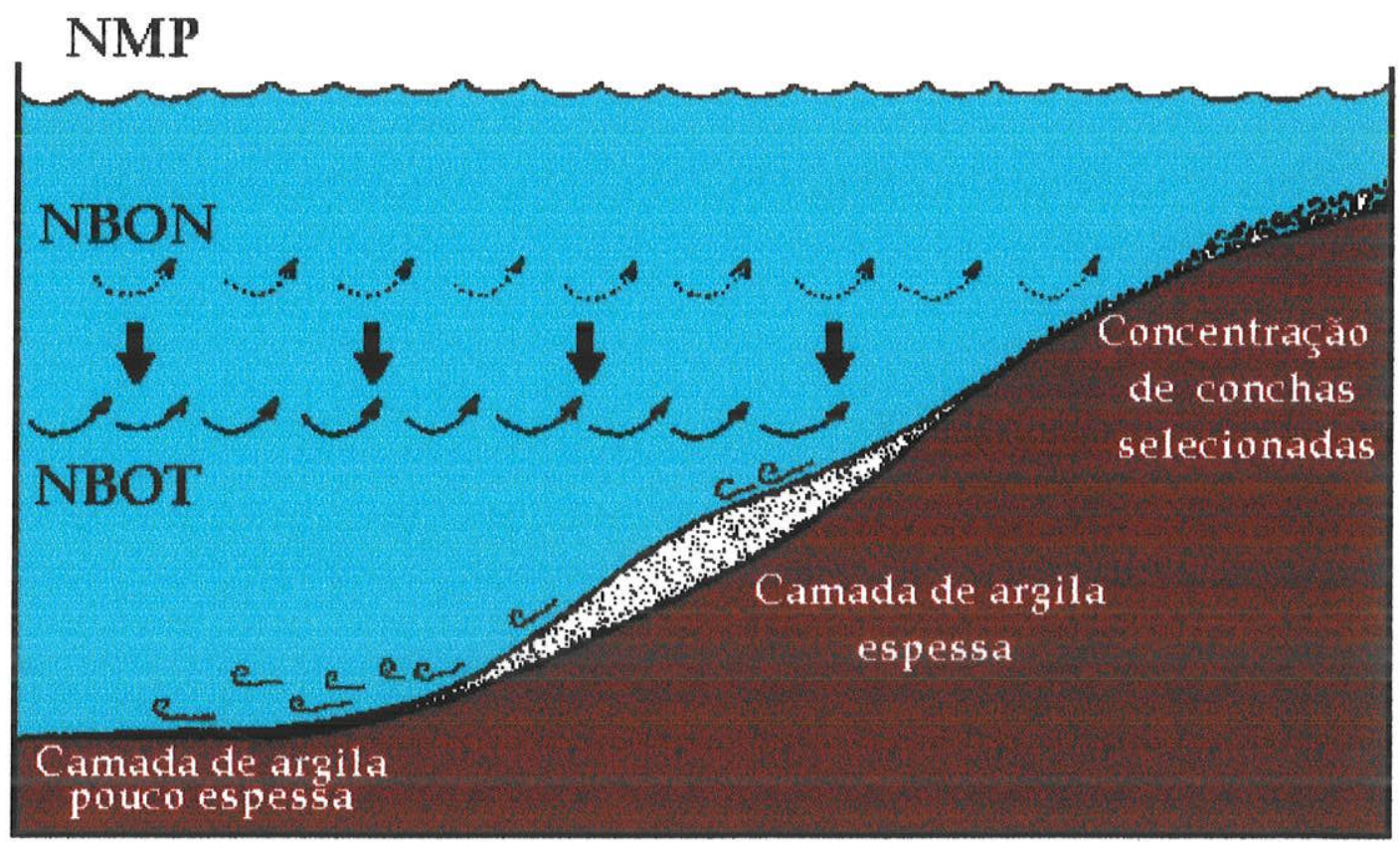

Figura 20. Modelo simplificado de evento de tempestade mostrando a posição batimétrica relativa de concentrações fossilíferas selecionadas e camadas de argila produzidas por um evento único de tempestade. Explicação: NMP: nível principal do mar; NBON: base das ondas normais; NBOT: base das ondas de tempestade. Escala verticalmente exagerada (modificado de Miller et al., 1988). 


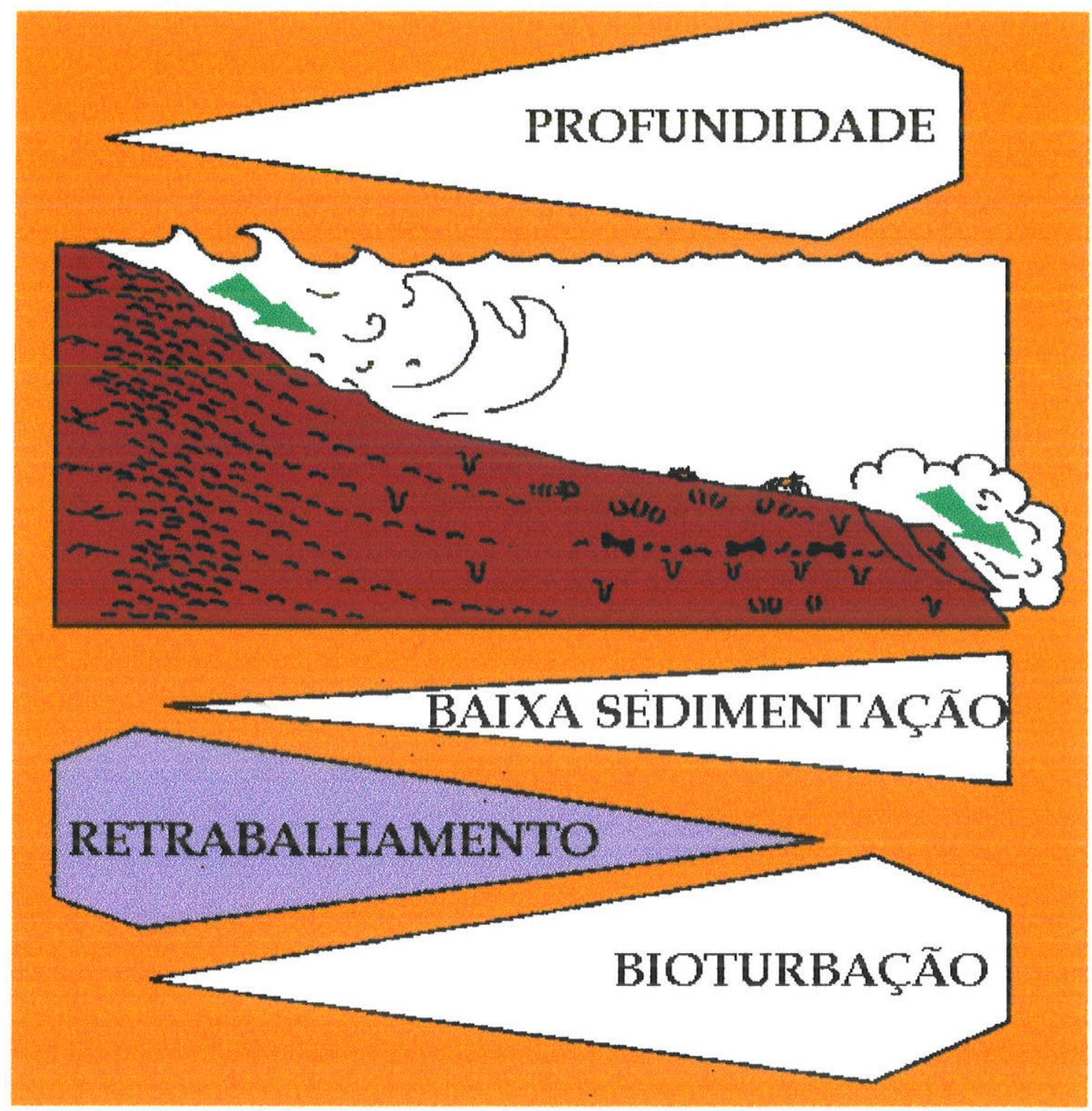

Fig. 21. Importância relativa dos processos que atuam na plataforma. Notar a intensidade dos processos de retrabalhamento em ambiente proximal (modificado de Norris, 1986).

A colonização de pavimentos de conchas por formas da infauna ou epifauna bissada corresponde ao processo de retroalimentação tafonômica reconhecido por Kidwell e Jablonski (1983).

O mecanismo básico de retroalimentação tafonômica inclui a acumulação lenta ou episódica dos restos esqueléticos autóctones ou alóctones, através de mecanismos 
autogênicos (e.g., produtividade biológica local) ou alogênicos (e.g., transporte de bioclastos por correntes). Este acúmulo, transforma o fundo mole e instável em substrato duro e estável, próprio para a colonização por animais epibentônicos. A colonização é favorecida também pela inibição do desenvolvimento de infauna de substrato mole (Kidwell e Jablonski, 1983; Kidwell, 1986a, 1991; Simões, 1998).

Outro fator importante relativo à retroalimentação tafonômica diz respeito à taxa de sedimentação, que no caso de colonização de substratos duros e estáveis por elementos da epifauna, deve ser muito baixa ou ausente (Simões, 1998).

Desta maneira, a presença de conchas articuladas fechadas de Naiadopsis lamellosus na concentração fossilifera $\mathrm{C}$ é atribuída à recolonização de substrato composto por bioclastos já retrabalhados, alguns fragmentados, depositados por um evento de tempestade anterior, por elementos da epifauna e, no caso, da semi-infauna bissada. A alternância entre períodos de soterramento e exposição das conchas, produzida pelo retrabalhamento imposto pelos eventos de tempestade, deu origem a uma concentração fossilifera amalgamada, onde duas ou mais comunidades estão misturadas.

Segundo Miller et al. (1988), concentrações fossiliferas amalgamadas e repetidamente retrabalhadas podem incluir uma assembléia bem preservada, in situ, na superficie da concentração (epifauna bissada) representando o evento de soterramento final que não sofreu erosão pela ação de tempestade posterior. Esta assembléia, recoberta abruptamente por sedimento fino, é preservada em razão da mudança do nível de base das ondas de tempestade.

A deposição de sedimentos finos, em ambiente marinho, está associada ao transporte de lama em suspensão, em direção à parte mais distal da plataforma, durante eventos de tempestade. Estes sedimentos finos decantam-se rapidamente na região próxima ou logo abaixo do nível de base das ondas de tempestade.

Peterson (1985) observou um acúmulo de aproximadamente $10 \mathrm{~cm}$ de sedimento síltico na laguna Mugu, California, durante uma tempestade que causou sedimentação catastrófica. Este mesmo autor, durante observações de campo e experimentais, analisou a capacidade de escape de elementos da infauna e epifauna após a deposição de material fino. Concluiu que a capacidade de escape ao soterramento abrupto é maior em animais detritívoros da infauna e sucessivamente menor em organismos suspensívoros da infauna 
e da epifauna bissada. Porém, de acordo com Miller et al. (1988), alguns organismos da epifauna podem provavelmente sobreviver a uma deposição de aproximadamente $2 \mathrm{~cm}$ ou menos de sedimento e porções do pavimento de conchas podem permanecer livres de material fino.

A mortalidade em massa da epifauna sob condições de deposição de camadas de sedimento fino $(>2 \mathrm{~cm})$ deve-se a impossibilidade de escape destes organismos bissados, ou ainda ao entupimento do sistema respiratório por lama. $O$ mesmo ocorre com a semiinfauna bissada, como é o caso de Naiadopsis lamellosus, presente na concentração fossilifera $C$, preservada em posição de vida.

A concentração $C$ apresenta, como vimos, alguns exemplares de um bivalve da semi-infauna bissada, Naiadopsis lamellosus, preservado em posição de vida, associado a elementos da infauna que apresentam qualidade de preservação variada. São encontradas também, conchas articuladas fechadas associadas a conchas desarticuladas, sendo as primeiras atribuídas à Naiadopsis lamellosus.

As conchas de Naiadopsis lamellosus apresentam-se tanto desarticuladas como articuladas fechadas, algumas em posição de vida. A presença de conchas da semiinfauna bissada desarticuladas, em diversos estados de preservação, indica a ocorrência de vários eventos de colonização de substrato duro e estável, formado por conchas de bivalves, e retrabalhamento deste substrato por eventos de alta energia entre a base das ondas normais e a base das ondas de tempestade. Esta mistura de elementos da infauna e semi-infauna bissada em um único horizonte é resultado de retrabalhamento e reexposição de bioclastos em ambiente proximal (Miller et al., 1988).

A ocorrência de conchas desarticuladas, fragmentadas e que sofreram abrasão misturadas a conchas articuladas fechadas da mesma espécie, preservadas in situ, no topo da concentração fossilífera, comprova o alto grau de mistura temporal da concentração. A preservação deste produto final só foi possível devido à mudança da base das ondas de tempestade, estando a concentração fossilífera $\mathrm{C}$ preservada abaixo da base destas.

As evidências acima indicam que, na concentração $C$, diferentes espécies dentro da mesma concentração fossilifera, apresentam diferentes graus de mistura temporal, 
constituindo um excelente exemplo de mistura temporal desarmoniosa (Kowalewski, 1996).

Do ponto de vista genético, a concentração fossilifera $\mathrm{C}$ representa um depósito de tempestito distal (Fürsich e Oschmann, 1993). A seqüência de eventos que provavelmente deu origem a concentração fossilifera $C$ (Fig. 22) pode corresponder à seqüência B-I-C-D-K-F-L. Deve-se notar, porém, que o número de vezes que os eventos se repetiram e a ordem em que ocorrem pode ter se alterado durante os vários eventos geradores da concentração fossilífera. 


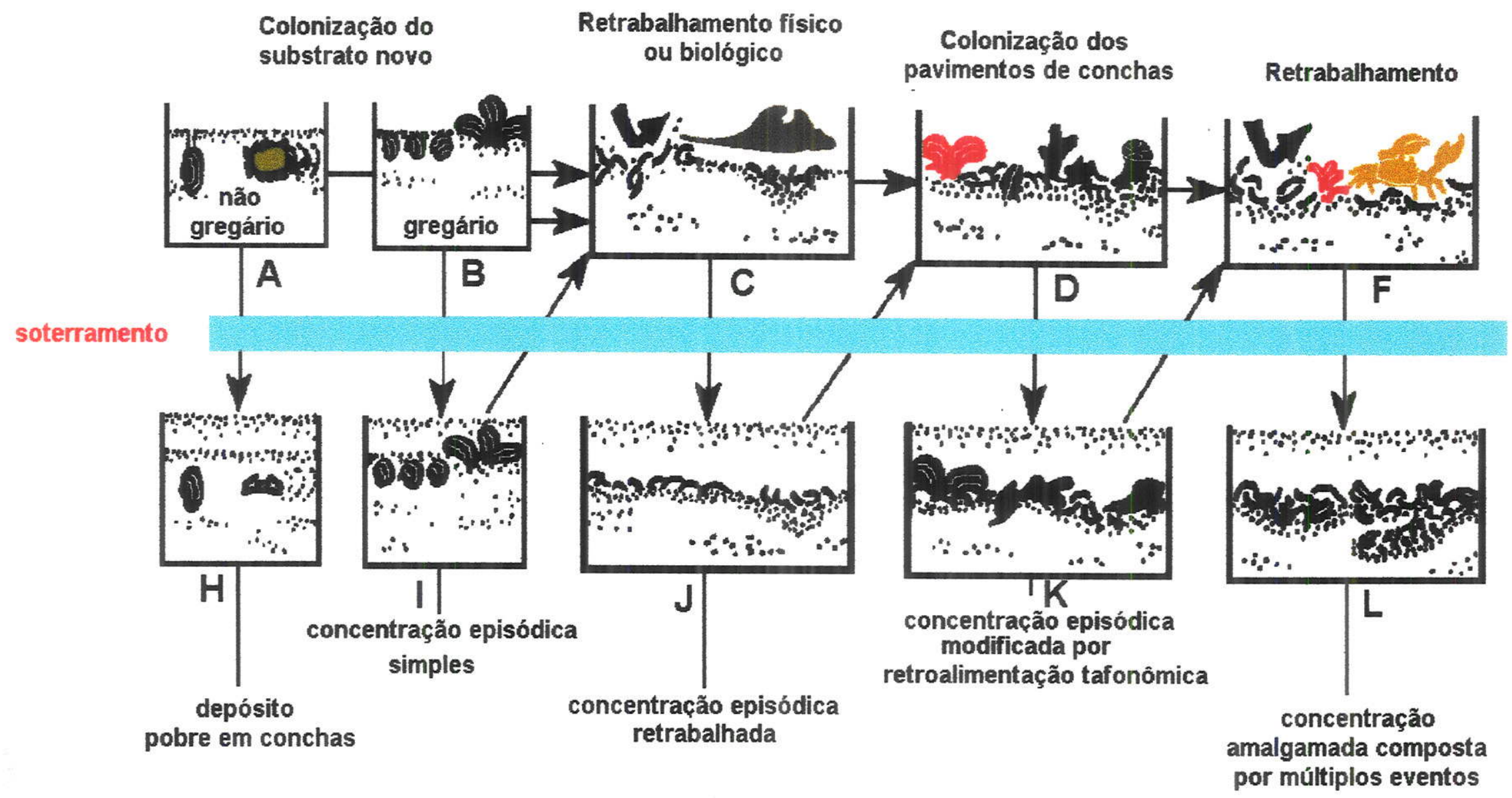

Figura 22. Relações entre o processo de colonização do substrato e as interações entre organismos vivos e restos esqueléticas já depositados no fundo, as taxas de sedimentação e os processos sedimentares e seus respectivos produtos (modificado de Kidwell, 1991). 


\subsection{CONCENTRAÇÃO FOSSILÍFERA D}

Descricão. A concentração fossilifera 4 possui aproximadamente $10 \mathrm{~cm}$ de espessura, contato basal brusco e erosivo e está localizada no afloramento 3, em terras do Sítio São Roque ( $21^{\circ} 38^{\prime} 76^{\prime \prime} \mathrm{S}$ e $\left.47^{\circ} 14^{\prime} 15^{\prime \prime} \mathrm{W}\right)$. A geometria da concentração não foi observada devido a intensa vegetação.

Os bioclastos encontram-se dispersos em matriz arenosa, estando arranjados de maneira caótica na matriz. As valvas estão desarticuladas em sua totalidade, não sendo encontrados bioclastos articulados fechados ou abertos. Dentre as valvas desarticuladas, $28,08 \%$ são valvas direitas e $71,92 \%$ valvas esquerdas.

É importante notar que entre as valvas de Cowperesia anceps, a proporção de valvas direitas e esquerdas é semelhante. Por outro lado, dentre as conchas de Pinzonella neotropica, as valvas esquerdas representam $77,32 \%$ do total. A maioria das conchas não está fragmentada (60\%), porém $40 \%$ encontram-se fragmentadas, fragmentação que pode ter ocorrido durante coleta e preparação.

Esta concentração fossilifera é composta predominantemente por Pinzonella neotropica (47,39\%) existindo também Cowperesia anceps (26,93\%) e Terraiopsis aequilateralis $(0,43 \%)$. Dentre as valvas coletadas não foi possivel identificar $26,65 \%$ do total. A Figura 23 mostra a distribuição das classes de tamanho de Pinzonella illusa e Cowperesia anceps.

Discussão. Conforme mencionado na discussão referente às concentrações fossiliferas 1 e 2, a biofábrica e as assinaturas tafonômicas fornecem informações sobre a natureza complexa das concentrações fossiliferas. As assinaturas tafonômicas permitem analisar os processos que atuaram no ambiente de origem dos bioclastos (processos tafonômicos de fundo), enquanto a natureza da matriz (e.g., grau de empacotamento) traz informações a respeito dos processos finais de concentração (Davies et al., 1989; Fürsich e Oschmann, 1993). 


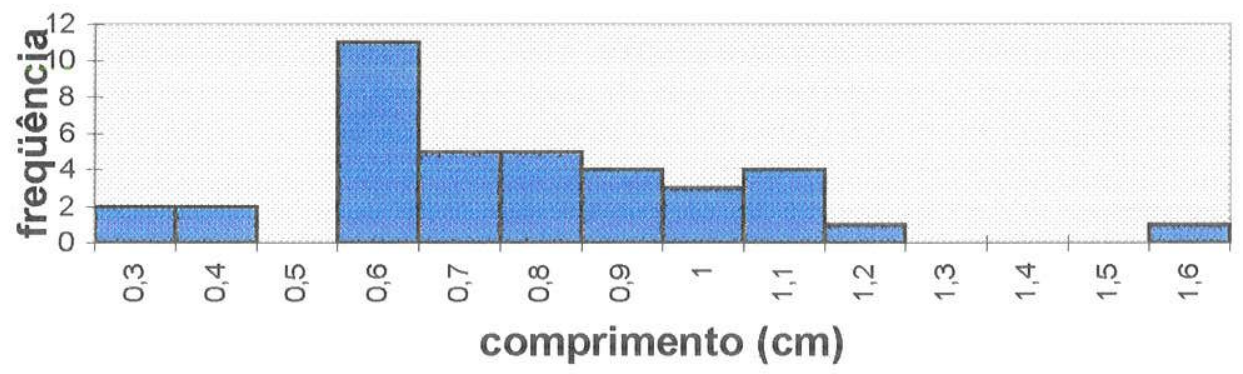

A

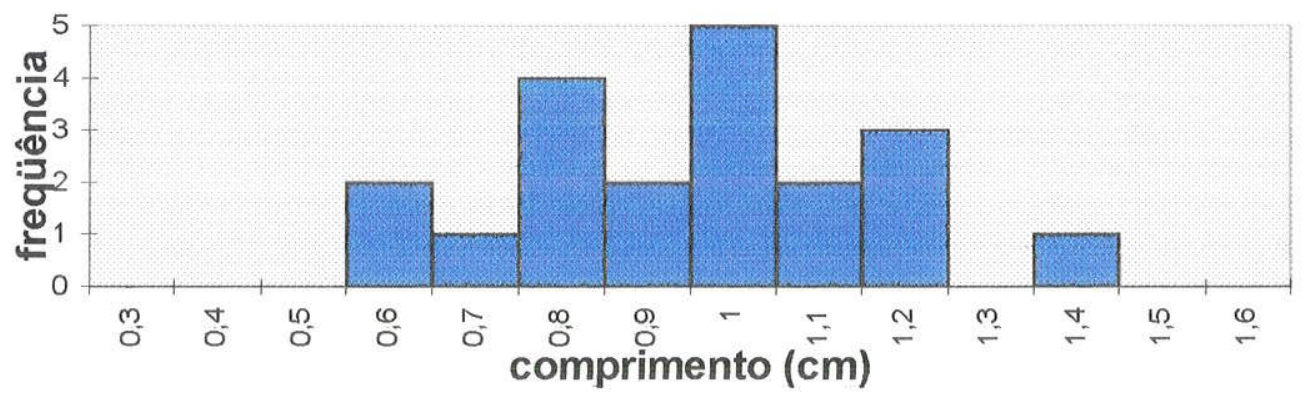

B

Figura 23. Distribuição das classes de tamanho de Pinzonella neotropica e Cowperesia anceps na concentração fossilífera C. Explicação: A= Pinzonella neotropica e B=Cowperesia anceps. 
Desta maneira, a natureza dispersa dos bioclastos na matriz, característica da concentração fossilifera 4 , reflete a atuação de processos finais de concentração, através de tempestades. Esta característica sugere não ter havido de seleção granulométrica da matriz siliciclástica e ter sido curto o período de tempo de atuação dos processos de erosão, retrabalhamento e seleção, durante o evento episódico.

Por outro lado, a seleção com relação as valvas direitas e esquerdas revelam a intensidade dos processos que atuaram no ambiente de origem dos bioclastos (processos tafonômicos de fundo) que correspondem ao dia-a-dia.

Apesar de o período de seleção ter sido curto, houve tempo suficiente para a seleção de valvas dos bivalves. Esta seleção é notada quando a proporção de valvas esquerdas e direitas é analisada. Do total de conchas analisadas, 77,92\% são valvas esquerdas e $28,08 \%$ valvas direitas. Vale notar que entre as conchas de Cowperesia anceps, a proporção de valvas direitas e esquerdas é semelhante. Por outro lado, dentre as conchas de Pinzonella neotropica, as valvas esquerdas representam $77,32 \%$ do total. $\mathrm{O}$ fato de as valvas esquerdas predominarem dentre o total de valvas atribuídas a Pinzonella neotropica é facilmente explicado quando o tamanho das valvas desta espécie é analisado. Esta espécie apresenta valvas direitas e esquerdas de tamanhos diferentes, são inequivalves, sendo que a valva esquerda apresenta comprimento maior, conforme mencionado anteriormente.

A ocorrência de exposição dos bioclastos na interface água-sedimento, antes do soterramento final, também fica clara através da presença de somente conchas desarticuladas nesta concentração. Não são encontradas conchas articuladas fechadas ou abertas que indicariam rápido soterramento e curto retrabalhamento na interface água/sedimento. Durante a movimentação lateral e/ou deriva da concha, por ação de correntes e ondas, durante o retrabalhamento na interface água/sedimento, ocorre a desarticulação. Este processo de desarticulação das valvas, principalmente em ambiente bem oxigenado, pode se dar em poucas semanas (Schafer, 1972).

A análise da biofábrica pode também trazer informações a respeito dos processos do dia-a-dia que atuaram antes do soterramento final (processos de fundo). Porém, para esta concentração fossilífera, não foi possível analisar alguns aspectos referentes a 
biofábrica devido a impossibilidade de orientação das amostras durante a coleta dado o intemperismo dos sedimentos. Embora tenha sido notado no campo que os bioclastos encontram-se arranjados caoticamente em matriz arenosa, a quantidade de conchas arranjadas com a convexidade para cima ou para baixo não foi mensurada.

Nota-se também, que a maioria dos bioclastos não se apresenta fragmentada, refletindo baixo grau de retrabalhamento e energia durante os processos do dia-a-dia, suficiente apenas para selecionar as valvas direitas e esquerdas.

Apesar de poucos dados terem sido extraidos desta concentração fossilifera, pode-se propor ter sido ela gerada durante evento de alta energia, demonstrado pelo arranjo caótico dos bioclastos em matriz arenosa e contato inferior brusco e erosivo. Além disso, o alto grau de seleção de valvas direitas e esquerdas indica um retrabalhamento anterior ao soterramento final, representando eventos de fundo, ou seja, que atuaram no dia-a-dia.

Vale ressaltar também, que de acordo com as características propostas por Fürsich e Oschmann (1993) esta concentração fossilifera representa um tempestito proximal. 


\section{MODELO DE TAFOFACIES PARA O GRUPO PASSA DOIS (EXCLUSIVE FORMAÇÃO RIO DO RASTO)}

GENERALIDADES. As assinaturas tafonômicas, tais como, o grau de desarticulação das conchas, orientação dos bioclastos na matriz, grau de empacotamento, grau de fragmentação e, grau de corrosão e incrustação dos restos esqueléticas, podem ser empregadas na caracterização de concentrações esqueléticas com diferentes estilos de preservação, permitindo o estabelecimento das chamadas facies tafonômicas.

Facies tafonômicas, como o próprio nome indica, são definidas com base em características tafonômicas (Speyer e Brett, 1988), particularmente bioestratinômicas. Características diagenéticas podem ser empregadas apenas subsidiariamente nas facies de águas mais profundas, devido ao seu uso limitado na avaliação das condições ambientais e do tempo e local de soterramento (Speyer, 1985, 1987, 1990, 1991). A história tafonômica de uma concentração fossilífera relaciona-se ao ambiente de deposição e as condições de sedimentação, refletindo feições tafonômicas distintas (Speyer e Brett, 1988). Dentre os diferentes tipos de esqueletos (maciços, arborecentes, univalves e multielementares), as conchas bivalves destacam-se, pois apresentam uma ampla gama de assinaturas tafonômicas que podem ser quantificadas (e.g., abrasão, desarticulação) (Speyer e Brett, 1988).

Estudos de tafofacies em depósitos de intermarés e plataforma rasa (e.g., Meldhal e Flessa, 1990) do Recente, mostram que cada litofacies reflete as condições de energia do ambiente e, deste modo, as assinaturas tafonômicas das acumulações esqueléticas associadas refletem a história post-mortem dos organismos. Por exemplo, enquanto as concentrações caracterizadas por bioerosão e incrustação são encontradas em ambientes de baixa energia e águas mais profundas, particularmente marcadas por baixa taxa de sedimentação (Brett e Baird, 1986), as acumulações esqueléticas geradas em ambiente de alta energia, sob condições de águas rasas e baixa taxa de sedimentação, caracterizam-se por altos índices de abrasão e fragmentação.

Embora o modelo de facies tafonômicas de Speyer e Brett (1988) tenha sido elaborado com base nas características tafonômicas de acumulações esqueléticas geradas em mar epicontinental do Paleozóico (Hamilton Group, Devoniano, New York), as 7 
tafofacies propostas (informalmente designadas por números: de 1 a 7) não podem ser facilmente, nem integralmente, reconhecidas no registro sedimentar do Grupo Passa Dois. De fato, conforme destaca Simões et al. (submetido), durante a deposição dos sedimentos do Grupo Passa Dois, particularmente após a deposição da Formação Irati, o gradiente topográfico da Bacia do Paraná parece ter sido muito reduzido (Daemon e Quadros, 1970; Rohn, 1994, Rohn et al., 1995), faltando, deste modo, condições batimétricas para a geração de tafofacies tipicamente de águas profundas, comuns no Grupo Hamilton (Speyer e Brett, 1988). Porém, desde que a maioria das concentrações fossilíferas geradas em mares epicontinentais são produto de eventos de tempestades (Brett e Baird, 1986, 1993, 1997; Simões, 1992, 1996a, 1998; Speyer, 1988; Speyer e Brett, 1986, 1988, 1991) e, tendo em vista que estes produzem efeitos previsíveis, invariavelmente relacionados à erosão do fundo, seleção e cobertura lamosa (e.g., Miller et al., 1988; Simões et al., submetido) é possível modelar as facies tafonômicas segundo esses efeitos (= "tempestite proximality"; Simões et al., submetido), os quais terão influência sobre: a) qualidade de preservação (sensu, Fürsich e Oschmann, 1993); b) espessura e geometria das concentrações (Fürsich e Oscmann, 1993; Brenchley e Harper, 1998) e, c) complexidade interna das acumulações esqueléticas (Simões, 1998; Simões e Kowalewski, 1998a,b; Simões et al., submetido).

Esta questão, entretanto, não é assim tão simples, pela interação de vários fatores, dos quais destacam-se:

a) turbulência versus taxa de sedimentação. $O$ grau de fragmentação, seleção, abrasão e a proporção de conchas articuladas geralmente decresce com o decréscimo da turbulência, na direção da plataforma profunda. Mas, o padrão de preservação poderá ser extremamente complexo, uma vez que tais características são também controladas pelas taxas de sedimentação. Estas, por sua vez, determinam a extensão e o tempo sob os quais os bioclastos estarão sujeitos à ação dos fenômenos mecânicos, químicos e biológicos de destruição das partículas bioclásticas;

b) taxa de sedimentação versus taxa de subsidência. Baixas taxas de subsidência estão associadas a baixas taxas de acumulação de sedimentos, as quais, por sua vez, estão associadas a altas taxas de fragmentação dos bioclastos 
(Simões, 1996a; Brenchley e Harper, 1998). Entretanto, fósseis comumente fragmentados por bioerosão podem ser gerados em ambientes de plataforma profunda, sob condições de baixa energia;

c) disponibilidade dos bioclastos versus hidrodinâmica do ambiente deposicional. Como regra geral, acumulações esqueléticas geradas em águas rasas são mais espessas, onde bioclastos gerados pela produtividade biológica de comunidades dominadas por bivalves são comuns (Kidwell e Brenchley, 1994, 1996). Particularmente nos mares epicontinentais, as concentrações esqueletéticas mais espessas ocorrem em ambiente proximal, diminuem sua espessura em direção à plataforma profunda, uma vez que diminuem aí também a erosão do substrato e o transporte de sedimentos por agentes tracionais de fundo (correntes).

De acordo com as assinaturas tafonômicas (Fürsich e Oschmann, 1993) e o grau de complexidade interna das concentrações (Simões e Kowalewski, 1998a), 5 tafofacies foram reconhecidas no Grupo Passa Dois (formações Serra Alta, Terezina e Corumbataí), representando apenas ambientes siliciclásticos. Entretanto, a fim de evitar um raciocínio circular, as tafofacies foram inicialmente descritas e sua gênese interpretada, independentemente de sua posição estratigráfica. Somente após este procedimento, a distribuição vertical das tafofacies identificadas foi determinada, com base no arcabouço estratigráfico disponível na literatura (Sousa, 1985; Rohn, 1994). A seguir, serão sucintamente descritas as 5 tafofacies propostas, segundo sua distribuição ao longo de um perfil de águas rasas a profundas (Fig. 24):

TAFOFACIES 1. Inclui concentrações fossiliferas suportadas por bioclastos, densamente empacotados, caoticamente orientados, com espessura variando de 2 a $15 \mathrm{~cm}$, com intraclastos sílticos. Sua geometria é lenticular, podendo apresentar dezenas ou, mais raramente, centenas de metros de extensão lateral. Os bioclastos apresentam diversas classes de tamanhos, incluindo desde conchas fragmentadas, até conchas grandes, medindo mais de $3 \mathrm{~cm}$. Todas as conchas estão desarticuladas. $\mathrm{O}$ contato basal é brusco e erosivo, o contato superior é brusco, às vezes, ondulado. No geral, os sedimentos (siltito ou argilito) que recobrem bruscamente a concentração são maciços, de espessura 
centimétrica. Internamente, as concentrações fossilíferas exibem gradação descontínua, além da presença de bioclastos empilhados e aninhados. Os bivalves comumente encontrados são os elementos das assembléias de Pinzonella illusa e Pinzonella neotropica e restos de peixes.

Interpretacão. As assinaturas tafonômicas sugerem exumação, retrabalhamento e prolongada exposição dos bioclastos na interface água/sedimento, sob condições de baixa ou intermediária taxa de sedimentação. Os altos índices de fragmentação, desarticulação e abrasão, sugerem fortemente que tais feições foram geradas em ambiente proximal, acima da base das ondas de bom tempo. Porém, a presença de base erosiva, gradação descontínua e bioclastos aninhados e empacotados é indicativa da ocorrência de fluxos de tempestades (Fürsich e Oschmann, 1986, 1993). A natureza amalgamada da concentração registra múltiplos eventos de erosão, retrabalhamento e deposição sob baixa taxa de sedimentação (Simões, 1996a; Simões et al., 1994, 1996a). O contínuo retrabalhamento dos bioclastos provavelmente inibiu a colonização do topo das concentrações por elementos da epifauna bissada.

Exemplos típicos. Coquina de Camaquã, assembléia de Pinzonella neotropica, parte superior da Formação Corumbataí, Rio Claro, SP; coquina de Pinzonella neotropica, parte superior da Formação Terezina, Anhembi, SP; coquina de Pinzonella illusa, porção média da Formação Corumbataí (Simões, 1996a; Simões et al., 1994, 1996a), Rio Claro, SP. 


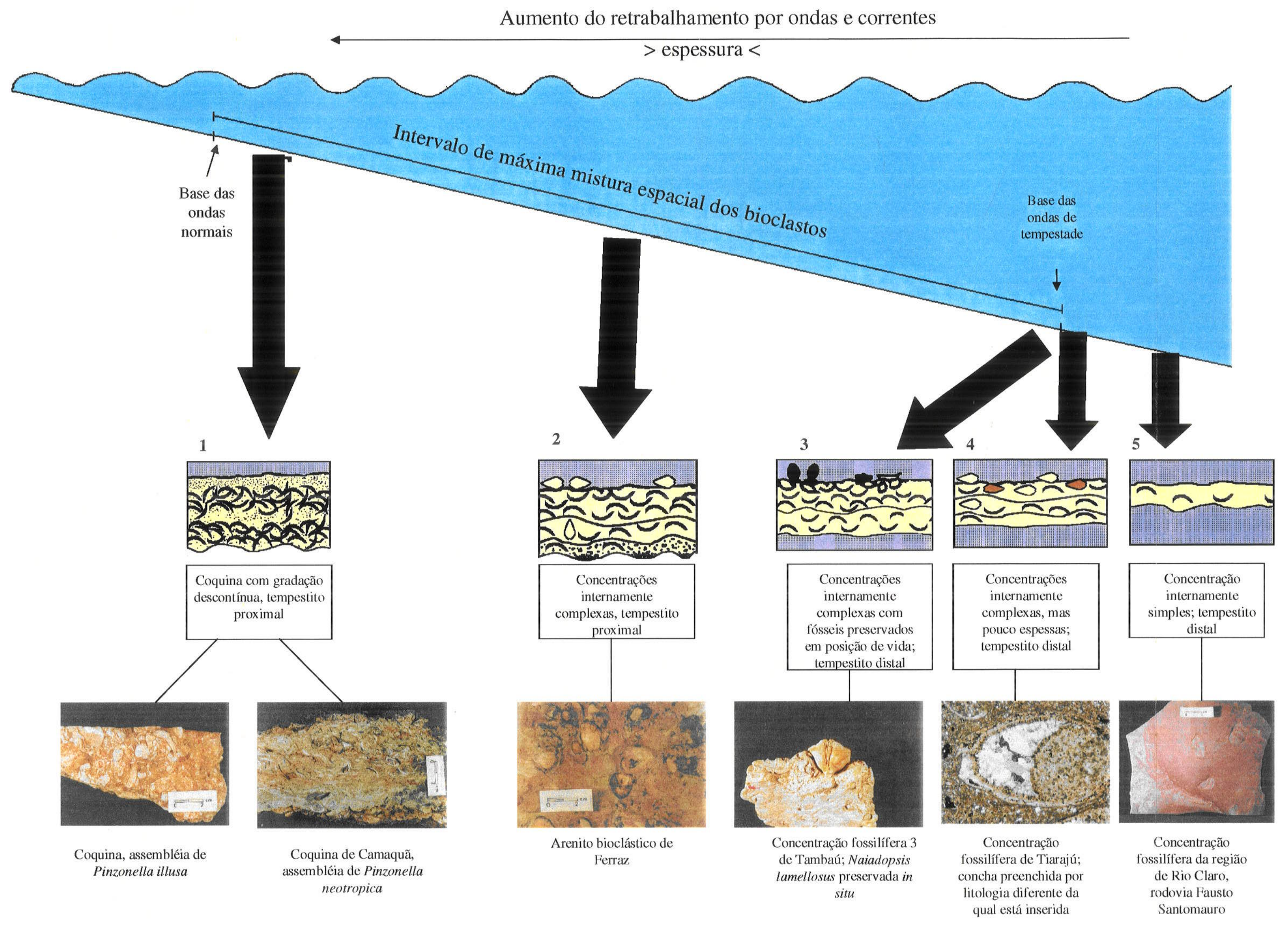

Figura 24. Modelo de facies tafonômicas para o Grupo Passa Dois (formações Serra Alta, Terezina e Corumbataí) ao longo de um perfil de águas rasas a profundas (Simões e Torello, em preparação). 
TAFOFACIES 2. Corresponde a concentrações fossiliferas representadas por arenitos bioclásticos, internamente complexos, normalmente com geometria lenticular. Sua espessura é variável, de 30 a $50 \mathrm{~cm}$. O contato basal é brusco, às vezes, erosivo e marcado por concentração formada por acúmulo denso de conchas fragmentadas dispostas ao acaso (depósito residual) (Simões, 1992, 1998; Simões e Kowalewski, 1998a,b). Em certos casos (e.g., Ferraz shellbed, sensu Simões e Kowalewski, 1998a,b) pelo menos 4 unidades microestratigráficas podem ser reconhecidas (Simões e Kowalewski, 1998a,b).

A unidade 1, com espessura variando de 1 a $3 \mathrm{~cm}$, estende-se lateralmente por cerca de $1 \mathrm{~m}$, formando lentes que preenchem depressões ao longo do contato com o siltito subjacente. $O$ contato superior é brusco e erosivo. Ocorre nivel com conchas imbricadas, porém a maioria destas encontra-se caoticamente distribuída na matriz e densamente empacotada, representada por conchas silicificadas, completas ou fragmentadas, variando de pequenas $(<2 \mathrm{~mm})$, até grandes $(>4 \mathrm{~cm})$.

A unidade 2 corresponde a corpos lenticulares de arenito bioclástico de aproximadamente $10-15 \mathrm{~cm}$ de espessura e extensão lateral de dezenas de metros. $\mathrm{O}$ contato basal brusco e erosivo e o superior gradual ou marcado por pavimentos de conchas, predominantemente com a convexidade voltada para cima. Grau de empacotamento dos bioclastos varia de frouxo (sensu Kidwell e Holland, 1991) a denso. Os bioclastos estão, em sua maioria, desarticulados, com a convexidade voltada para cima, embora associadamente raras conchas articuladas abertas ocorram. A maioria dos bioclastos não está fragmentada, porém freqüentemente mostram sinais de abrasão.

A unidade 3 possui espessura variando de 10 a $40 \mathrm{~cm}$, o contato basal é gradual ou bem marcado pela ocorrência de superficies contendo conchas com a convexidade voltada para cima. O contato superior é gradual. Os bioclastos apresentam-se dispersos ou frouxos na matriz, predominantemente perpendiculares ou oblíquos em relação ao plano de acamamento. Podem ser reconhecidos 3 horizontes de conchas desarticuladas, densamente empacotadas com a convexidade para cima, podendo ocorrer também conchas articuladas abertas.

A unidade 4 possui espessura variando de 6 a $10 \mathrm{~cm}$, e apresenta contato inferior gradual, e superior, com siltitos arroxeados, brusco. A maioria dos biociastos ocorre 
densamente empacotado, sendo que o grau de empacotamento aumenta em direção ao topo da unidade. Os bioclastos apresentam diversas classes de tamanho, estão em sua maioria desarticulados e preservados concordantemente ao plano de acamamento com as valvas com a convexidade para cima. Ocorrem conchas empilhadas e aninhadas e bioclastos com ampla variação na qualidade de preservação, incluindo conchas bem preservadas até profundamente desgastadas. A porção superior da unidade apresenta também conchas articuladas fechadas, em posição horizontal em relação ao plano de acamamento, além de conchas articuladas abertas. (Simões e Kowalewski, 1998a,b). Os fósseis presentes são: Pinzonella illusa, Terraiopsis aequilateralis, Plesiocyprinella carinata, Favalia arcuata, Holdhausiella elongata, Casterella gratiosa, Ferrazia cardinalis, ocorrência da assembléia de Pinzonella illusa. Já os elementos presentes nas concentrações fossiliferas da porção superior da Formação Corumbataí, na assembléia de Pinzonella neotropica, são Pinzonella neotropica, Cowperesia anceps, Terraiopsis aequilateralis e ostracodes.

Exemplos típicos. Arenito bioclástico de Ferraz, na parte inédia da Formação Corumbataí (Torello e Simões, 1994; Simões, 1996a, 1998; Simões e Kowalewski, 1998a,b); concentração fossilifera D, na parte superior da Formação Corumbataí da região de Tambaú; concentração fossilifera na parte média/superior da Formação Terezina, junto ao km 164 da Rodovia Castello Branco, (SP-280) (Sousa, 1985; Maranhão, 1995; Torello et al., 1997; Simões et al., submetido).

Comentários adicionais. É importante notar que algumas acumulações esqueléticas já descritas na literatura, aqui revisadas, contêm assinaturas tafonômicas características tanto da Tafofacies 1, quanto da Tafofacies 2. Elas são representadas por concentrações parcialmente silicificadas, com gradação descontínua, bioclastos suportados pela matriz e espessura variando de 3,5 a $6,5 \mathrm{~cm}$. O contato basal é brusco e erosivo, e as conchas, de diversos tamanhos, estão desarticuladas, fragmentadas ou não, com a convexidade para cima ou para baixo, empilhadas ou aninhadas, orientadas de preferência paralelamente aos planos de estratificação. Em planta, os bioclastos estão 
arranjados caoticamente na matriz. Os fósseis encontrados são Terraiopsis aequilateralis, Pinzonella illusa, Plesiocyprinella carinata e Ferrazia cardinalis.

Os altos valores de fragmentação de conchas são típicos da Tafofacies 1, enquanto alta proporção de matriz e conchas, mostrando pouco ou nenhum sinal de abrasão, são comuns na Tafofacies 2. Estas concentrações são geradas durante tempestades, incluindo assinaturas tafonômicas relacionadas aos processos de fundo e aos processos bioestratinômicos episódicos (Simões, 1996a).

Infelizmente, até o momento, somente raras amostras de procedência desconhecida, depositadas no Laboratório de Paleozoologia Evolutiva do Departamento de Zoologia, Instituto de Biociências da Unesp-Botucatu exibem as feições tafonômicas acima. Por esta razão, estas concentrações não foram atribuídas a nenhuma tafofacies, do presente modelo.

TAFOFACIES 3. São representadas por concentrações internamente complexas, de contato basal brusco e erosivo. A espessura é variável (máximo de $6 \mathrm{~cm}$ ), mas sua geometria não pode ser determinada com precisão. $\mathrm{O}$ contato superior é brusco e possivelmente ondulado. Os bioclastos são suportados pela matriz, representada por argilito. No geral, o grau de empacotamento é variável, aumentando para o topo da concentração. Tanto em planta, como em seção, os bioclastos, de diversas classes de tamanho, estão caoticamente distribuídos na matriz e conchas preservadas em posição de vida podem ocorrer no topo da concentração. Ao lado de conchas articuladas, ocorrem conchas desarticuladas, sem sinais de desgaste mecânico, além de outras, fragmentadas ou inteiras (predominantes), mostrando sinais de abrasão. Os elementos presentes são: Pinzonella neotropica, Cowperesia anceps, Jacquesia brasiliensis, Holdhausiella elongata e Naiadopsis lamellosus.

Interpretacão. A natureza complexa desta acumulação é indicada pela ampla variação das assinaturas tafonômicas, tais como mistura de conchas fragmentadas, com conchas em posição de vida, além de mistura de bivalves com modos de vida distintos. Base erosiva, abrasão e os altos índices de desarticulação são indicativos da ação de correntes tracionais de fundo, as quais raramente ocorrem abaixo da base das ondas de 
tempestade. Entretanto, a preservação de conchas em posição de vida, no topo da concentração, indica rápido soterramento por decantação de partículas finas, possivelmente associadas a fluxos de tempestade (Miller et al., 1988).

Três aspectos dessas concentrações merecem ser destacados: a) a colonização dos bioclastos do topo da coquina foi favorecida, por longos periodos de não deposição de argila ou sedimentos finos, facilitando o desenvolvimento da população de Naiadoposis lamellosus; b) a presença de conchas desarticuladas de Naiadopsis lamellosus, com grande variação de tamanho, desgastadas ou sem sinais de abrasão, no interior da concentração fossilífera, indica diversos episódios de colonização (eventos de fundo, sob baixa taxa de sedimentação), retrabalhamento e rápido soterramento (evento episódico), durante eventos de alta energia; e, c) a preservação de Naiadopsis lamellosus em posição de vida só foi possível porque, após o último evento de tempestade, novos eventos episódicos não produziram correntes ou fluxos capazes de atingir a concentração esquelética. Em outras palavras, a maior parte das assinaturas tafonômicas observadas é tipicamente gerada acima da base das ondas de tempestade, porém sua preservação final foi facilitada pela ausência de processos tracionais de fundo, sugerindo uma mudança do nível da base de ondas de tempestade.

Exemplo típico. Concentração fossilifera $\mathrm{C}$, na parte superior da Formação Corumbataí, região de Tambaú, SP.

TAFOFACIES 4. Inclui concentrações pouco espessas (máximo de $20 \mathrm{~cm}$ ), intercaladas em argilito laminado, com contatos basal e superior bruscos e matriz intensamente bioturbada. Os bioclastos, de tamanho variado, encontram-se caoticamente distribuídos na matriz, predominantemente desarticulados $(57,2 \%)$, embora conchas articuladas possam ser freqüentes $(42,8 \%)$ (Klein, 1997). Algumas conchas articuladas fechadas encontram-se preenchidas por litologia diferente da matriz onde estão inseridas. Ocorrem conchas fragmentadas e que sofreram abrasão, porém bioerosão e incrustação estão ausentes. Os elementos presentes são: Pinzonella tiarajuensis, Terraia altissima, Holdhausiella elongata, Jacquesia sp., Cowperesia ? emerita, Naiadopsis? sp. 
Interpretacão. Estas concentrações fossiliferas ocorrem intercaladas em espessos pacotes de siltito ou argilito, normalmente maciços, tanto na base da Formação Serra Alta, como no topo da Formação Terezina, no Estado do Rio Grande do Sul (Klein, 1997). Na Formação Serra Alta, argilitos e siltitos contêm concentrações fosfásticas, representadas por camadas com espessura variando de 0,7 a $3 \mathrm{~cm}$ e estendendo-se lateralmente por mais de 3 metros (Simões e Rohn, 1996). Estes sedimentos representam depósitos de alto mar. A ausência de bioturbação em certos intervalos indica prováveis condições anóxicas (Simões e Rohn, 1996). As finas camadas contendo sedimentos fosfatizados exibem contato basal brusco e erosivo com o siltito, refletindo processos erosivos associados a correntes induzidas por tempestades. Estes eventos foram, entretanto, de energia moderada, tendo em vista a ausência de seleção das partículas fosfáticas (Simões e Rohn, 1996). O processo de fosfatização ocorre normalmente em ambientes marinhos semi-abertos contendo matéria orgânica em abundância (Brett e Baird, 1986; Föllmi et al., 1991; Simões e Rohn, 1996). Para que possa ter ocorrido a fosfatização, os restos orgânicos devem ter sido rapidamente soterrados e submetidos a um período de baixa sedimentação e erosáo, propiciando assim tempo suficiente para a fosfatização (Brett e Baird, 1986; Föllmi et al., 1991; Simões e Rohn, 1996). Por outro lado, tendo em vista que os níveis fossiliferos são verticalmente restritos no pacote de argilitos (e.g., base da Formação Serra Alta) e, tendo em vista, que estes estão associados a finas (centimétricas) camadas de arenitos, de base erosiva, há a possibilidade de relação entre a melhoria nas condições de oxigenação de fundo e eventos de tempestades (Mello et al., 1998; Simões et al., 1998a,b).

A história tafonômica complexa destas concentrações é indicada pela mistura de conchas articuladas, sem sinais de abrasão, com conchas que sofreram algum desgaste, conchas desarticuladas e conchas com a cavidade preenchida por litologia diferente à qual estão inseridos. Alguns destes bioclastos encontram-se parcialmente preenchidos por carbonato espático e matriz micrítica mais fina (Klein, 1997; Klein et al., 1997a,b). A associação de bioclastos articulados fechados preenchidos por litologia igual a de sua matriz e bioclastos preenchidos por litologia diferente reflete mistura de elementos esqueléticas mais antigos, dentro de uma assembléia mais nova, por processo de exumação ou retrabalhamento, indicando assim certo grau de mistura temporal. Estes 
dados sugerem, portanto, baixo entendimento temporal e espacial (Klein, 1997; Klein et al., 1997a,b; Simões et al., submetido).

Exemplos típicos. Concentrações da região de Tiarajú, RS, na rodovia TiarajúCoxilha do Pau Fincado, a aproximadamente $3 \mathrm{~km}$ do Monumento Tiarajú-Sepé, onde afloram sedimentos da Formação Terezina (Klein, 1997); concentrações representadas por concreções fossiliferas, Formação Serra Alta, Rodovia Castello Branco, (SP-280), SP (km 160,650 e 161,5 (Mello et al., 1998); concentrações fosfáticas da região de Porangaba, km 161,5, Rodovia Castello Branco, (SP-280) SP (Simões e Rohn, 1996).

TAFOFACIES 5. São representadas por concentrações fossilíferas internamente simples (Kidwell et al., 1986, p. 231), sempre associadas a argilitos maciços, freqüentemente bioturbados. As conchas estão frouxamente empacotadas ou dispersas (Kidwell e Holland, 1991) na matriz Em planta, as conchas apresentam-se paralelas ao plano de acamamento, com a convexidade voltada para cima (predominante) ou para baixo. Predominam as conchas desarticuladas, embora conchas articuladas abertas sejam freqüentes $(1,95 \%)$. Sinais de desgaste não são observados nas conchas. Os elementos característicos são: Barbosaia angulata, Casterella camargoi, Mendesia piracicabensis, Holdhausiella elongata, Antraconaia sp e Maackia sp., na base da Formação Corumbataí, a aproximadamente $5,0 \mathrm{~m}$ acima do contato com a Formação Irati (Ghilardi et al., 1997), na região de Rio Claro; Pinzonella neotropica e Cowperesia anceps, na parte superior da Formação Corumbataí, concentrações fossilíferas A e B de Tambaú, SP e bivalves da assembléia de Pinzonella illusa, na parte média da Formação Corumbataí, arredores da cidade de Leme, SP.

Interpretacão. A ausência de conchas fragmentadas, o alto índice de articulação de algumas acumulações esqueléticas, a alta proporção de matriz e a ausência de feições indicativas de acentuado transporte por tração são sugestivos de deposição abaixo da base das ondas de tempestade. As diversas classes de tamanho observadas possivelmente refletem diversos episódios de morte natural das populações de bivalves (Walker e Bambach, 1971; Brenchley e Harper, 1998). Entretanto, não pode ser esquecido que 
bivalves escavadores só são exumados quando mortos (Kondo, 1997, 1998) e que desarticulação só ocorre após exumação (Brett e Baird, 1986; Kondo, 1998). Portanto, duas hipóteses poderiam explicar a ocorrência de conchas desarticuladas de bivalves da infauna, nesta tafofacies, ou seja: a) raros eventos episódicos mais energéticos seriam capazes de causar alguma erosão do substrato, mesmo abaixo da base das ondas de tempestades (Brett e Baird, 1997) e exumar os animais mortos; ou b) estes seriam remobilizados pelos animais bentônicos responsáveis pela bioturbação do substrato. Evidências tafonômicas (alto índice de articulação, ausência de conchas fragmentada) e sedimentológicas (Sousa, 1985) favorecem a primeira alternativa.

Exemplos típicos. Concentrações fossiliferas localizadas em afloramento situado na Rodovia Fausto Santomauro (SP-127), na parte inferior da Formação Corumbataí (Ghilardi et al., 1997); concentrações fossiliferas A e B (presente documento), parte superior da Formação Corumbataí, Tambaú, SP; concentração fossilífera localizada na área de extração de argila da cerâmica Maristela, em frente à estátua do Cristo da cidade de Leme, Rodovia Anhanguera (SP-330), km 192 sentido capital interior (Simões et al., em preparação).

\section{DISCUSSÃO}

$\mathrm{O}$ modelo de facies tafonômicas aqui proposto difere dos publicados na literatura brasileira por abranger um espectro maior de facies, incluindo também as de águas relativamente mais profundas (abaixo da base das ondas de tempestade), cujos dados não estavam disponiveis à época de elaboração dos modelos de Rohn e Pennati (1993) e Simões (1996a). A sinonímia entre algumas das tafofacies sugeridas e as já disponiveis na literatura é mostrada na Tabela 9. De um modo geral, as tafofacies aqui propostas podem ser reconhecidas em diferentes regiões da borda leste da Bacia do Paraná, estando presentes nos estados de São Paulo, Paraná e Santa Catarina, como os dados de literatura sugerem (Rohn e Penatti, 1993; Simões, 1996a).

Conforme demonstrado, a maior parte das concentrações fossiliferas preservadas nas tafofacies propostas são o produto final da atuação de processos sedimentares (e.g., erosão do substrato, seleção, rápida deposição) associados à tempestades. Neste 
contexto, dois grandes grupos de acumulações podem ser reconhecidas, incluindo: a) acumulações originadas pela mistura de arenitos transportados por correntes de fundo, induzidas por tempestades e material colocado em suspensão pelas ondas de tempestade (Simões e Kowalewski, 1998a); e b) acumulações produzidas pelo retrabalhamento, seleção e ressuspensão de sedimentos finos (siltito, argilito) autóctones.

Arenitos finos interpretados como tempestitos proximais (Torello e Simões, 1994; Simões, 1996a, 1998; Simões e Kowalewski, 1998a,b), intercalados em espesso pacote de lamitos, não são comuns nas formações Terezina e Corumbataí, sendo as melhores ocorrências verificadas na região de Rio Claro (Mendes, 1952; Landim, 1970; Ragonha, 1980; Sousa, 1985; Maranhão, 1995). Ragonha (1980) observou que os arenitos são finos, homogêneos e selecionados, tendo sido retrabalhados originalmente a partir de areias costeiras. De fato, a presença de grãos foscos indica que tais sedimentos foram retrabalhados por ventos na área fonte (Ragonha, 1980). Entretanto, por representarem tempestitos proximais, esses depósitos refletem a habilidade das ondas de tempestades retrabalharem os sedimentos da costa, e deslocado para o interior da bacia. A presença de base erosiva, de depósitos residuais basais ou concentrações bioclásticas preenchendo depressões escavadas do substrato pré-existente (siltito) (Simões, 1992, Fig. 20; Simões e Kowalewski, 1998a, plate 47, Fig. 1), indica o rigor com que os processos erosivos e de acumulação dos bioclastos, relacionados aos processos de tempestade atuaram junto ao fundo. Estas concentrações são tipicamente geradas na plataforma, entre o nível de base das ondas de bom tempo e o nível de base das ondas de tempestades e são denominadas de internamente complexas (Simões, 1998; Simões e Kowalewski, 1998a). A ocorrência de lâminas descontínuas de argilito ou siltito e de pavimentos de conchas retrabalhadas, lateralmente restritos, sugere, como já referido, que esses arenitos são o produto de diversos episódios de acreção e eliminação (seleção) de sedimentos finos, sugerindo que sua acumulação se deu num longo intervalo de tempo, provavelmente $10^{2}-10^{4}$ anos (Simões, 1998; Simões e Kowalewski, 1998a,b).

No outro extremo dos dois grande tipos de acumulações observadas, estão as coquinas e outras concentrações onde os bioclastos estão mais densamente empacotados. Conforme bem exemplificado pela concentração $C$, descrita nesta dissertação, tais acumulações são provavelmente o produto final de episódios de 


\begin{tabular}{|c|c|c|}
\hline $\begin{array}{l}\text { Tafofacies 1: O mesmo que Tafofacies } 3 \\
\text { de Simóes (1996) }\end{array}$ & $\begin{array}{l}\text { Tafofacies 1: Altos valores de } \\
\text { desarticulaçao, reorientaçăo, seleça, } \\
\text { fragmentaçăo e abrasåo. Assinaturas } \\
\text { tafonômicas caracteristicas de ambiente } \\
\text { mais destrutivo, proximal, acima da base } \\
\text { das ondas de bom tempo, com atuação de } \\
\text { fluxo de tempestade. }\end{array}$ & $\begin{array}{l}\text { Tafofacies l: O mesmo que tafofacies } 1 \text { de } \\
\text { Simós (1996). }\end{array}$ \\
\hline $\begin{array}{l}\text { Tafofacies 2: Valvas inteiras, pouco } \\
\text { selecionadas, grau de empacotamento } \\
\text { varia de frouxo a densamente empacotada. } \\
\text { Representa tempectito. }\end{array}$ & $\begin{array}{l}\text { Tafofacies 2: Altos valores de } \\
\text { fragmentaça, alta proporya de matriz } \\
\text { siliciclástica e conchas apresentando pouco } \\
\text { ou nenhum sinal de abrasão. } \\
\text { Concentraçoes geradas durante } \\
\text { tempestades, com assinaturas tafonômicas } \\
\text { relacionadas aos processos } \\
\text { bioestratinômicos de fundo. }\end{array}$ & $\begin{array}{l}\text { Tafofacies 2: O mesmo que Tafofacies } 3 \\
\text { de.Simð̌es (1996). }\end{array}$ \\
\hline $\begin{array}{l}\text { Tafofacies 3: Valvas inteiras, algumasd } \\
\text { fragmentadas, mal ou bem selecionadas, } \\
\text { geralmente com convexidade para cima, } \\
\text { bioclastos frouxos na matriz Representa } \\
\text { tempestito. }\end{array}$ & $\begin{array}{l}\text { Tafofacies 3: Unidade basal composta por } \\
\text { oonchas fragmentadas, contato brusco e } \\
\text { erosivo. Unidade acima com conchas } \\
\text { desarticuladas em bom estado de } \\
\text { preservaçăo, aninhadas e empithadas, } \\
\text { concordantes ao plano de acamamento. } \\
\text { Unidade superior com conchas } \\
\text { desarticuladas e articuladas fechadas e } \\
\text { abertas, conchas empithadas e aninhadas } \\
\text { são comuns. Concentraçăo gerada por } \\
\text { evento de alta energia. Rápido } \\
\text { retrabalhamento e redeposiça sob alto } \\
\text { grau de sedimentaçáo entre a base das } \\
\text { ondas normais e detempestade }\end{array}$ & 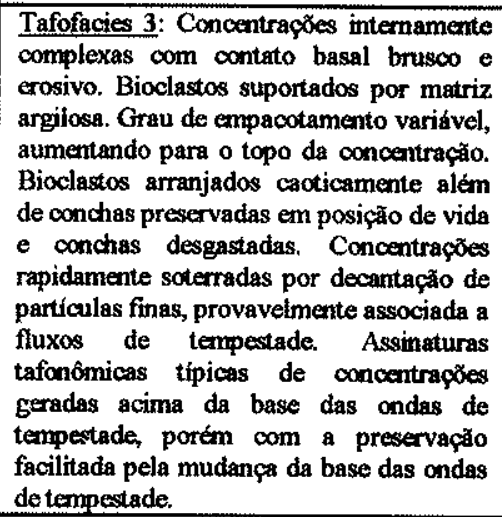 \\
\hline \multirow[t]{2}{*}{$\begin{array}{l}\text { Tafofacies 4: O mesmo que Tafofacies } 1 \\
\text { de Simoes (1996) }\end{array}$} & & $\begin{array}{l}\text { Tafofacies 4: Concentraçao pouco espessa, } \\
\text { conchas desarticuladas, articuladas } \\
\text { frequentes, algumas sofreram abrasåo. } \\
\text { Algumas conchas articuladas preenchidas } \\
\text { por litologia diferente da matriz em que } \\
\text { estâo inseridas. Mistura de elementos } \\
\text { esqueléticas mais antigos dentro de uma } \\
\text { assembléia mais nova por processo de } \\
\text { exumação ou retrabalhamento. Tempestito } \\
\text { distal. }\end{array}$ \\
\hline & & $\begin{array}{l}\text { Tafofacies 5: Concentracão intemamente } \\
\text { simples, bioclastos paraleios ao plano de } \\
\text { acamamento com convexidade para cima } \\
\text { ou para baixo. Maioria conchas } \\
\text { desarticuladas, porém conchas articuladas } \\
\text { são frequentes. Alto indice de conchas } \\
\text { articuladas, alta proporçẫo de matriz e } \\
\text { ausência de feiçes indicativas de } \\
\text { acentuado transporte por traçăo sugerem } \\
\text { deposição abaixo da base das ondas de } \\
\text { tempestade. }\end{array}$ \\
\hline
\end{tabular}

Tabela 9. Comparação entre as tafofacies propostas por autores prévios (Rohn e Penatti, 1993 e Simões, 1996a) e no presente trabalho. 
retrabalhamento e seleção de lamitos, sem a adição de sedimentos alóctones. Curiosamente, entre estes dois tipos de concentrações existem outras acumulações esqueléticas (coquina de Pinzonella illusa; Simões et al., 1994) que parecem representar o produto final de retrabalhamento dos arenitos bioclásticos. Essas coquinas são raras no registro fossilifero, incluindo apenas táxons (Pinzonella illusa e Plesiocyprinella carinata) dominantes e com conchas mais espessas, comuns das assembléias representadas nos arenitos bioclásticos. Adicionalmente, estão presentes também na matriz, intraclastos representados por siltito e argilito silicificados, que parecem corresponder ao retrabalhamento das lâminas de siltito e argilito que ocorrem no interior dos arenitos bioclásticos. Além disso, os intraclastos estão imbricados na base da concentração esquelética, indicando a atuação correntes unidirecionais. Se a interpretação acima estiver correta, é possível que essas acumulações indiquem importantes paradas na sedimentação e/ou episódios de retrabalhamento, mostrando variações na dinâmica deposicional, durante intervalo de tempo superior a $10^{4}$ anos, particularmente no intervalo compreendido pela parte média da Formação Corumbataí, onde elas são encontradas.

Em decorrência das relações existentes entre qualidade de preservação das partículas bioclásticas, taxas de sedimentação e nível de energia do meio, já mencionadas anteriormente, as facies tafonômicas variam de modo previsível, também, nas seqüências sedimentares e paraseqüências.

Considerando o registro estratigráfico das flutuações do nível marinho, taxas de sedimentação e outros fatores ambientais associados, observa-se que, em condições de trato de mar baixo ou no início de eventos transgressivos, os restos esqueléticos apresentam baixa qualidade de preservação, com a ocorrência generalizada de bioclastos apresentando altos índices de corrosão, fragmentação e desarticulação (Brett, 1995). Tais assinaturas tafonômicas estão associadas às condições de águas pouco profundas, dominantes nos intervalos representativos de águas mais rasas do cicio transgressivoregressivo (Brett e Baird, 1986).

Vários autores (e.g., Posamentier e Vail, 1988; Posamentier et al., 1988; Loutit et al., 1988), por outro lado, demonstraram que eventos transgressivos são seguidos de importantes períodos de baixa taxa de sedimentação ou mesmo de não deposição de 
sedimentos, tanto nos ambientes de águas mais profundas, como nos de águas rasas. Em decorrência destas condições, os bioclastos são expostos a longos períodos de residência na interface água/sedimento (Kidwell e Bosence, 1991) e sujeitos aos processos de desarticulação e abrasão. Parece, portanto, haver correlação entre eventos transgressivos e a gênese de coquinas (Brett, 1995; Simões, 1996a,b).

Coincidentemente, no Neopaleozóico da Bacia do Paraná, concentrações fossilíferas, correspondentes à tafofacies 1 são comuns no Grupo Passa Dois, no intervalo correspondente à parte superior das formações Terezina e Corumbataí, na assembléia de Pinzonella neotropica, quando importantes episódios de mudanças do nivel de base da bacia (transgressões) parecem ter ocorrido (Rohn, 1994; Rohn et al., 1995), sob condições de baixa taxa de sedimentação (Simões, 1996a,b). É justamente neste intervalo que parece ter existido condições para a formação mais freqüente de tempestades que transportaram sedimentos siliciclásticos finos para as porções mais distais da bacia, dando origem aos chamados depósitos de rápida sedimentação (“obrution deposits"; Brett, 1995; Brett et al., 1997).

No Grupo Passa Dois (exclusive Formação Irati), tais depósitos são encontrados também na porção superior da Formação Corumbataí (Simões et al., 1998a,b, submetido), caracterizando concentrações da tafofacies 3 , que contém animais da semiinfauna bissada, em posição de vida, o que só é possível a partir de mudança no nível de base de ondas de tempestade. Embora Brett (1995) tenha demonstrado que, de fato, coquinas e depósitos de "obrution" ocorrem numa mesma porção do ciclo transgressivoregressivo, esses depósitos são raros, no Grupo Passa Dois possivelmente, devido ao baixo gradiente topográfico da Bacia do Paraná, durante esta fase de sua história sedimentar (Rohn, 1994; Rohn, et al., 1995), permitindo o amplo retrabalhamento do fundo por processos tracionais, dificultando a preservação de tais concentrações. Quando presentes, porém, essas concentrações esqueléticas são um importante indicador de mudanças na dinâmica sedimentar (Ghilardi, 1999).

Durante os períodos de máxima inundação, as taxas de sedimentação no ambientes de costa afora são mínimas (Brett, 1995). Embora raramente os restos esqueléticos acumulados sob tais condições sejam remobilizados por correntes e outros agentes tracionais de fundo, os índices de desarticulação dos bioclastos são elevados, 
sendo em muitos casos passíveis de intensa corrosão (Brett e Baird, 1986, 1993). As acumulações esqueléticas geradas nesta fase são caracterizadas por pavimentos de conchas descontínuos e pouco espessos, com alta proporção de bioclastos desarticulados, como os encontrados na parte inferior da Formação Corumbataí (Maranhão, 1986; Ghilardi et al., 1997; Ghilardi, 1999) e na parte média da Formação Serra Alta (Maranhão, 1995; Torello et al., 1997; Mello et al., 1998), assembléia de Barbosaia angulata - Anhembia froesi (sensu, Rohn, 1994), tafofacies 5. Nesta porção do ciclo transgressivo-regressivo, formam-se também acumulações esqueléticas residuais ("lags"), particularmente constituídas por partículas bioclásticas quimicamente estáveis (e.g., fosfato; Brett e Baird, 1991). De fato, concentrações fosfáticas foram verificadas na Formação Serra Alta (Simões e Rohn, 1996) no mesmo intervalo de ocorrência das acumulações que caracterizam a tafofacies 5 . Faltam porém evidências estratigráficas para atribuir essas acumulações à base de paraseqüências (Simões e Rohn, 1996).

Durante o início dos eventos regressivos, as bacias epicontinentais encontram-se com o nivel do mar alto o suficiente para que as acumulações esqueléticas permaneçam, na sua grande maioria, abaixo da base das ondas de bom tempo (Brett, 1955). Porém, neste momento, amplas áreas da bacia podem ser atingidas por ondas de tempestades, remobilizando material já depositado ou transportando lateralmente bioclastos e outras partículas sedimentares. Deste modo, há um aumento nas taxas de sedimentação e, conseqüentemente, uma redução no tempo de exposição dos bioclastos, na interface água/sedimento. As concentrações geradas nesta fase tendem a ser internamente complexas (Simões, 1998; Simões e Kowalewski, 1998a) e caracterizadas por uma mistura de bioclastos bem preservados (e.g., articulados), com baixa porcentagem de fragmentação. As condições acima parecem ter caracterizado a parte média das formações Terezina e Corumbataí (Sousa, 1985; Rohn, 1994), assembléia de Pinzonella illusa (sensu Rohn, 1994), onde há ampla evidência sedimentológica e tafonômica de ocorrência de eventos de tempestade e variação nas taxas de sedimentação (Torello e Simões, 1994; Simões, 1996b, 1998; Simões e Kowaleski, 1998a,b), dando origem aos arenitos bioclásticos, comuns na tafofacies 2 .

Pelo exposto, é interessante observar que embora um arcabouço de estratigrafia de sequêencias não tenha sido proposto para o Grupo Passa Dois, a distribuição vertical 
das 5 tafofacies reconhecidas não se dá, aparentemente, de maneira aleatória. Por exemplo, tafofacies caracteristicamente de águas mais profundas (tafofacies 4 e 5) ocorrem no intervalo da assembléia de Barbosaia angulata - Anhembia froesi, litoestratigraficamente equivalente a porção inferior da Formação Corumbataí, onde provavelmente predominaram condições de águas mais profundas, abaixo ou logo acima da base das ondas de tempestade. Já as tafofacies 1 e 2 , de águas mais rasas parecem estar restritas aos intervalos de deposição das assembléias de Pinzonella illusa e Pinzonella neotropica, que litoestratigraficamente correspondem à porção média da Formação Corumbataí e superior da Formação Terezina (Ronh, 1994; Maranhão, 1986). Segundo Sousa (1985) e Rohn (1994), neste intervalo predominaram na Bacia do Paraná condições de águas rasas, com diversos períodos importantes de baixa taxa ou não deposição dos sedimentos (Simões, 1996; Simões e Kowalewski, 1998a,b). Consequentemente, as concentrações fossilíferas deste intervalo são amalgamadas, evidenciando sua história complexa, caracterizada por eventos de fundo e episódicos.

Diversos autores (Sousa, 1985; Rohn, 1994; Rohn et al., 1995, Klein, 1997; Klein et al., 1997a,b), entretanto, notaram importantes variações no nível de base da Bacia do Paraná, rumo ao topo das Formações Corumbataí e Terezina (Rohn, 1994). Tais variações são registradas pela tafofacies 3 , em que há mistura de assinaturas tafonômicas geradas tanto acima como abaixo da base das ondas de tempestade. Em certas regiões da borda leste, como no Rio Grande do Sul, os sedimentos do topo da Formação Terezina caracterizam ambiente de baixa energia, sem agitação por ondas ou correntes (Klein, 1997). Consequentemente, a tafofacies aí preservada (Tafofacies 4) mostra características de águas mais profundas, como as presentes na Formação Serra Alta, na região nordeste da Bacia do Paraná.

Neste contexto, haveria boa relação entre as litofacies das Formações Serra Alta, Terezina e Corumbataí (Sousa, 1985; Rohn, 1994) e as tafofacies aqui definidas, segundo um perfil de águas rasas para profundas. Entretanto, uma comparação detalhada entre o modelo proposto, com os disponiveis na literatura, tanto para o Paleozóico (e.g., Speyer, 1987; Speyer e Brett, 1988, 1991), como para o Mesozóico (e.g., Fürsich e Oschmann, 1993), mostra claramente a ausência de registro de tafofacies de "águas mais 
profundas", em concordância com o que ocorre na Bacia do Paraná, na qual prevaleceram condições de águas mais rasas, durante a deposição do Grupo Passa Dois. 


\section{ALGUMAS QUESTÕES CONCEITUAIS}

\subsection{A MISTURA TEMPORAL VERSUS VARIAÇÃO MORFOLÓGICA INTRAESPECÍFICA EM CONCHAS DE BIVALVES.}

Conforme mencionado anteriormente, a ampla base de dados de campo e literatura gerada durante a confecção do presente documento abriu a possibilidade para a discussão de temas tafonômicos mais amplos, tendo as concentrações fossilíferas do Grupo Passa Dois como exemplos.

A década de 1990, pode ser chamada a "década da tafonomia", no contexto da Paleontologia. Em especial grande atenção foi dispensada à origem das concentrações fossilíferas e definição espacial e temporal (Brett e Baird, 1997; Flessa, 1998; Flessa e Kowalewski, 1994; Flessa et al., 1993; Kidwell e Bosence, 1991; Kidwell e Behrensmeyer, 1993; Kidwell e Flessa, 1995; Kowalewski, 1996; Kowalewski et al., 1998). Estudos detalhados de concentrações fossiliferas do Paleozóico restringem-se, em grande parte, a exemplos dos mares epicontinentais do Devoniano (Brett e Baird, 1993; Brett et al., 1997) e Permiano (Simões e Kowalewski, 1998a,b; Simões et al., submetido).

No geral, todos os trabalhos tafonômicos reconhecem que a mistura temporal é um fenômeno natural nas concentrações fossiliferas marinhas, independentemente do seu modo de formação (processos e produtos). De fato, o grau de mistura temporal de uma dada concentração fossilífera é função da disponibilidade do bioclastos antigos no ambiente deposicional (Kowalewski, 1998; Kowalewski et al., 1998; Simões et al. 1998a,b; Simões et al., submetido), mais do que dos processos de deposição dos bioclastos. Portanto, diferentemente dos primeiros trabalhos das décadas de 1970 e, particularmente 1980, a questão da mistura temporal evoluiu, não estando mais restrita a simples constatação do fenômeno, mas sim, a sua precisa quantificação. Em outras palavras, qual deve ser a variação da idade individual dos bioclastos contidos numa dada amostra?

Graças ao desenvolvimento de técnicas menos dispendiosas e de alta precisão (14 C- calibrated amino acid racemization; Goodfriend, 1987, 1989; Goodfriend e Flessa, 
1997; Goodfriend e Gould, 1996; Goodfriend et al., 1995, 1997; Kowalewski et al., 1998), conchas de bivalves e gastrópodes de diferentes acumulações esqueléticas, num perfil de águas rasas a profundas, em ambiente marinho atual (Golfo da California) puderam ser datadas. Estes estudos mostram que $15 \%$ das conchas datadas apresentam idades superiores a 1000 anos, podendo atingir, entretanto, até 36.000 anos (Flessa e Kowalewski, 1994). Surpreendentemente, uma concha sem sinais de desgaste e perda de coloração tinha mais de 3000 anos (Kowalewski, 1998). Paralelamente, a datação radiométrica de conchas de bivalves de concentrações fossiliferas do Holoceno (e.g., "Cheniers"), rigorosamente coletadas todas em um mesmo plano de acamamento, mostrou que, em média, a diferença de idade entre as conchas novas e as antigas é de aproximadamente 600 anos. Estes dados sugerem mistura temporal da ordem de $10^{2}$ a $10^{4}$ anos, a julgar pelos dados do Recente (Simões e Kowalewski, 1998a,b).

A questão da mistura temporal tem várias implicações que transcendem a esfera paleontológica. Entretanto, a principal implicação do fenômeno é na análise paleontológica, uma vez que as concentrações fossiliferas preservam tipicamente restos esqueletéticos de organismos não contemporâneos, às vezes de comunidades distintas. Uma consequência direta do fenômeno é o enriquecimento ou aumento da variabilidade morfológica de um dado táxon, pela sucessiva mistura temporal de indivíduos de populações não contemporâneas. Embora este fato tenha sido previsto (Kidweil, 1986b; Kowalewski, 1998), ele não foi ainda rigorosamente testado.

Algumas concentrações fossiliferas das formações Corumbataí e Terezina podem ensejar interessante modo para a investigação desta questão. Na Formação Corumbataí da região de Anhembi, SP (Ribeirão Venda Velha), por exemplo, a coquina dominada por conchas de Pinzonella neotropica parece exibir as mesmas assinaturas tafonômicas e complexidade interna da coquina de Camaquã, também incluída na assembléia de Pinzonella neotropica. Evidências discutidas anteriormente (Simões et al., 1996a) sugerem que tais concentrações possuem alto grau de mistura temporal, provavelmente da ordem de milhares de anos (Simões et al., 1996a). Entretanto, diferentemente da coquina de Camaquã, a coquina de Anhembi pode, dado o grau de intemperismo da matriz, ser desagregada por meios químicos e as conchas ali densamente empacotadas, separadas, descritas e contadas. Foi constatado, que $99 \%$ das conchas presentes 
pertencem a Pinzonella neotropica. Porém, três morfotipos distintos são encontrados: a) conchas alongadas; b) conchas intermediárias; e c) conchas arredondadas.

A análise cladística destes e outros elementos da Família Pinzonelidae (Mello, 1999) mostra que os três morfotipos provavelmente não representam espécies distintas. Seria então a variação morfológica intraespecífica de Pinzonella neotropica função do alto grau de mistura temporal? Seria a variação morfológica fruto da mistura temporal e espacial? De que maneira a variação intraespecífica das conchas de Pinzonella neotropica se comporta em concentrações fossiliferas (por exemplo, concentração A de Tambaú), supostamente, com menor grau de mistura temporal?

Em primeiro lugar, desde que todas as conchas analisadas da região de Anhembi exibem alto grau de abrasão e desarticulação (100\%), fica aparentemente descartada a possibilidade desta mistura refletir o transporte lateral dos bioclastos de populações contemporâneas vivendo em diferentes ambiente. De fato, para os três morfotipos reconhecidos existem representantes de diversas classes de tamanho, desde conchas pequenas $(0,6 \mathrm{~cm})$ até grandes $(2 \mathrm{~cm})$. Sabidamente, o transporte lateral é um processo seletivo (Brett e Baird, 1986) e, portanto, quando ocorre mistura lateral, a concentração fossilífera, inclui bioclastos mostrando sinais de desgaste e outros exibindo excelente preservação. Além disso, determinadas classes de tamanho normalmente predominam, ocorrendo ainda mistura de organismos com modos de vida distintos. Nota-se que nenhuma destas características está presente na concentração esquelética examinada. Portanto, em principio, a primeira hipótese, ou seja de que a variação morfológica pode ser resultado de mistura temporal é viável.

A distribuição dos morfotipos identificados por Mello (1999) nas amostras de Anhembi e concentração A de Tambaú é mostrada nas Figs. 25, 26, 27 e 28. Somente dois dos morfotipos (A e B) ocorrem na concentração de Tambaú. 


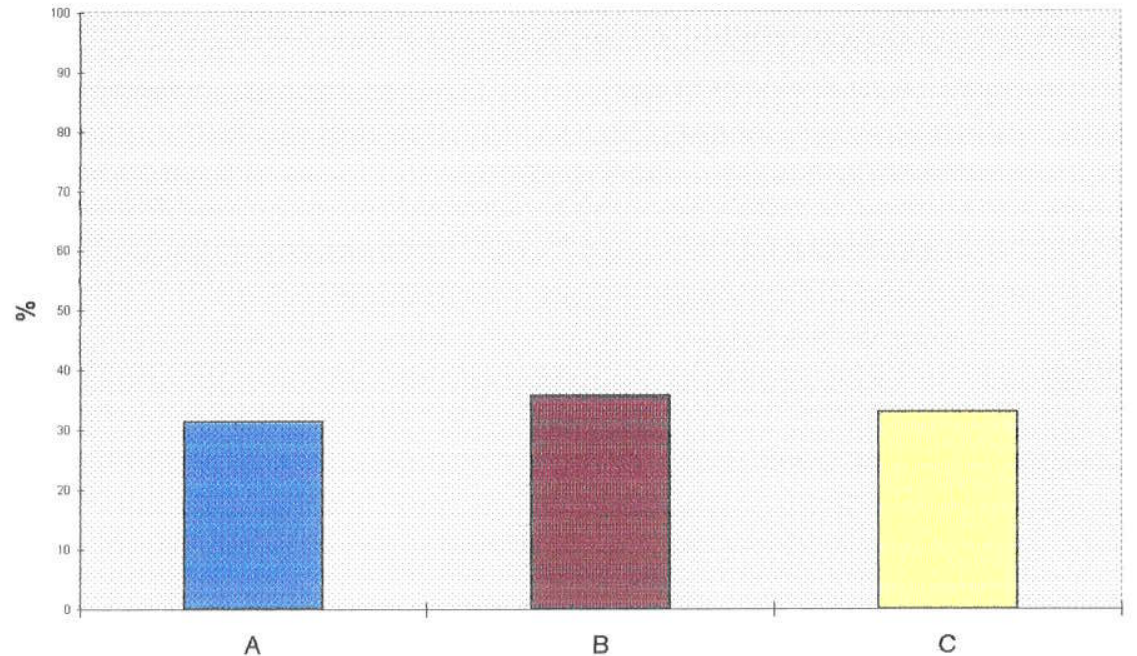

Figura 25. Proporção dos três morfotipos $(A, B, C)$ observada na concentração fossilífera de Anhembi, SP.

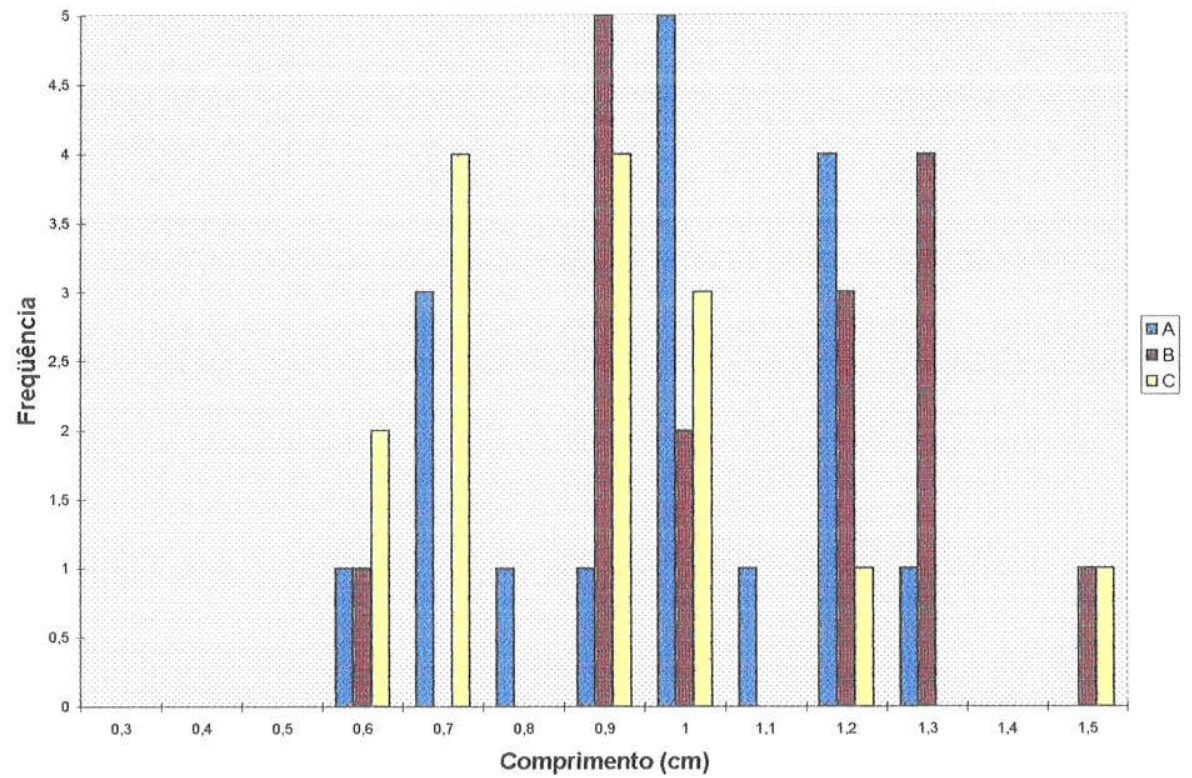

Figura 26. Classes de tamanho dos três mofotipos (A, B, C) da concentração fossilífera de Anhembi. 


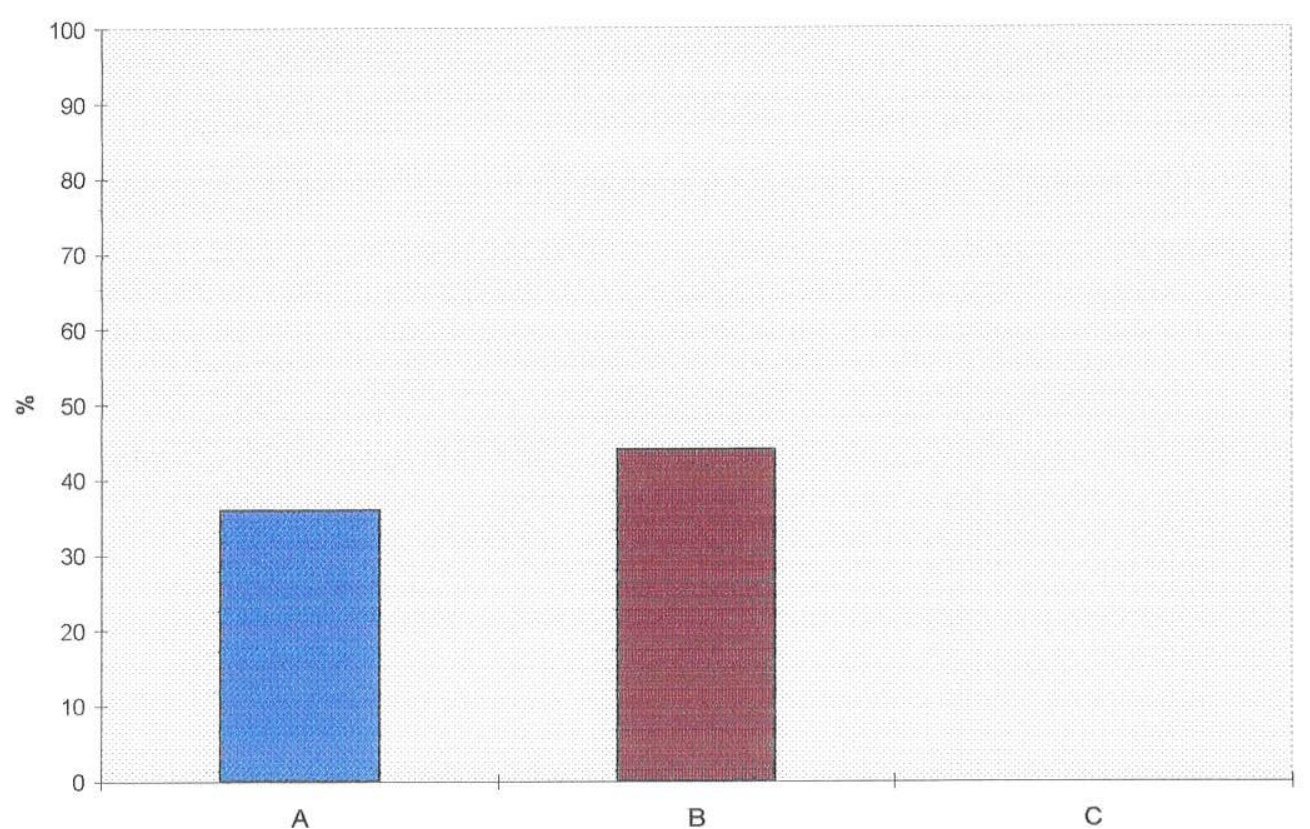

Figura 27. Proporção dos 3 morfotipos (A, B, C) observada na concentração fossilífera A de Tambaú

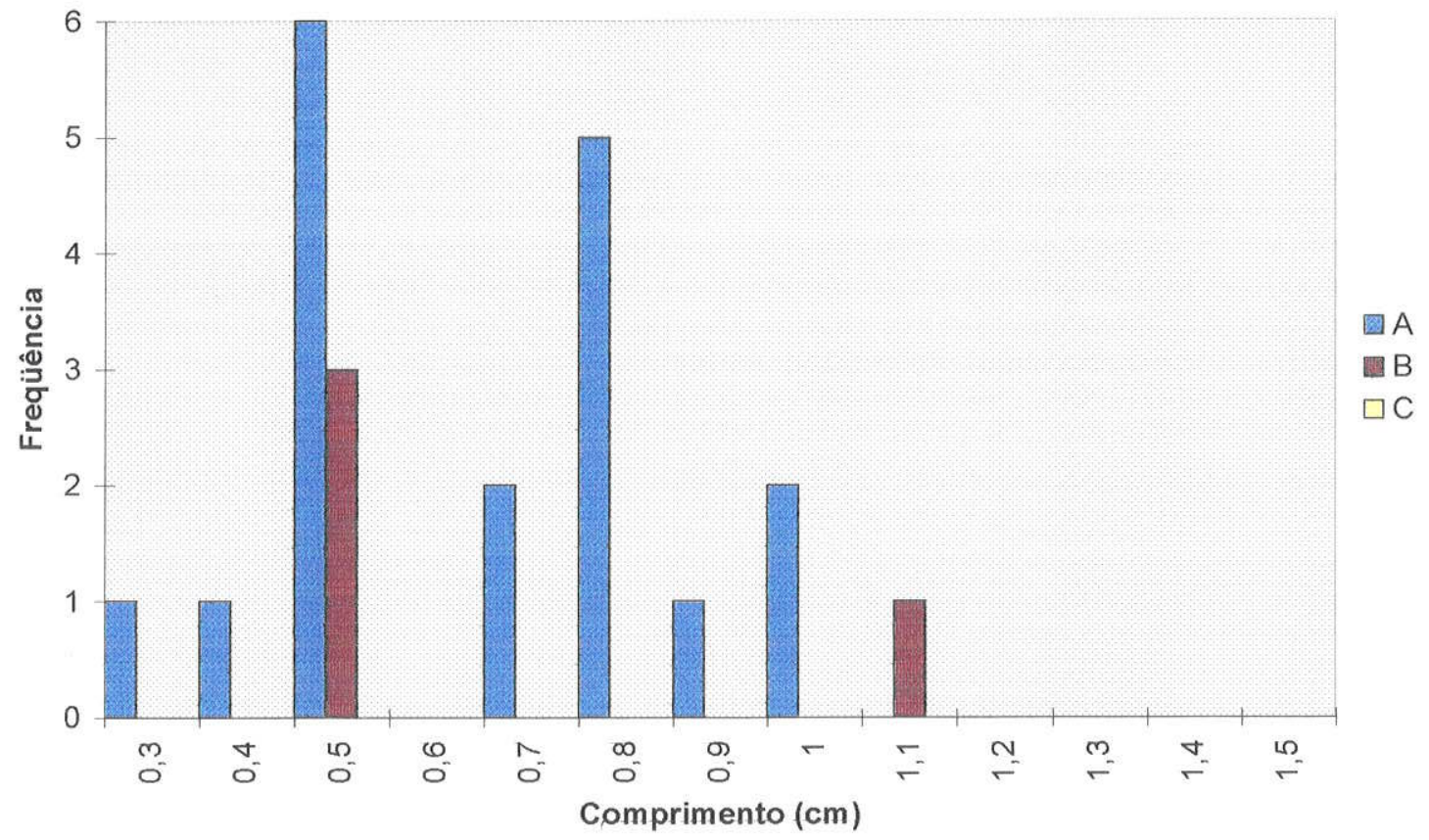

Figura 28. Classes de tamanho dos três morfotipos (A, B e C) da concentração fossilífera A de Tambaú. 
A concentração fossilifera A de Tambaú foi selecionada para estudo por três motivos: a) predomínio de conchas de Pinzonella neotropica, sem sinais de abrasão e com alto grau de articulação $(18 \%)$; b) a maior parte das medidas provém de um mesmo plano de acamamento, o que evita ao máximo a mistura por coleta ("time averaging" analítico, Fürsich e Aberhan, 1990); e c) as assinaturas tafonômicas, especialmente o alto grau de articulação de parte das conchas indica que, ao menos em parte, a concentração exibe grau de mistura temporal menor do que a coquina de Anhembi e Camaquã.

A fim de analisar os dados fornecidos e verificar se as proporções dos três morfotipos são diferentes nas concentrações fossilíferas citadas anteriormente, foi empregado o teste estatístico $\chi^{2}$ (e.g., Sokal e Rohlf, 1995; Zar, 1996) para 4 concentrações fossiliferas onde as formas das conchas de Pinzonella neotropica foram analisadas. As concentrações fossiliferas analisadas foram:

1) concentração fossilífera A (afloramento 1) da região de Tambaú;

2) concentração fossilífera $C$ da região de Tambaú;

3) concentração fossilifera de Camaquã, região de Rio Claro-SP;

4) concentração fossilifera da região de Anhembi, SP, Ribeirão Venda Velha.

$O$ resultado obtido foi $\chi^{2}=39,44$, gl $=6$ e $p=5,87$, onde gl refere-se ao grau de liberdade e p a probabilidade, podendo-se concluir, com os valores obtidos e comparação com tabela estatística, que as proporções das formas A, B e C são estatisticamente diferentes entre os vários locais de coleta.

Desta maneira, os dados mostram que as concentrações fossiliferas onde a mistura temporal é maior, ou seja, 3 e 4, a mistura de conchas de Pinzonella neotropica de diferentes formas é mais notável. Nestes locais, a proporção de valvas das formas $\mathrm{A}$, B e C é semelhante. $\mathrm{O}$ mesmo não ocorre em concentrações onde o grau de mistura temporal não é alto ( 1 e 2), nas quais alguma das formas pode estar ausente ou ocorrer em proporção baixa (Fig. 29).

Em conclusão, portanto, a presença de conchas de Pinzonella neotropica dos três morfotipos, em uma mesma concentração fossilifera, é indicativa de alto grau de mistura temporal. 


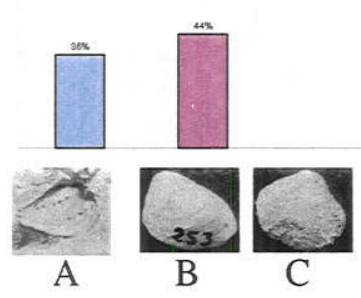

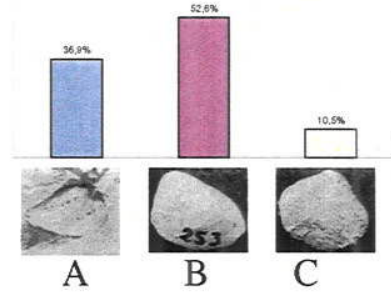

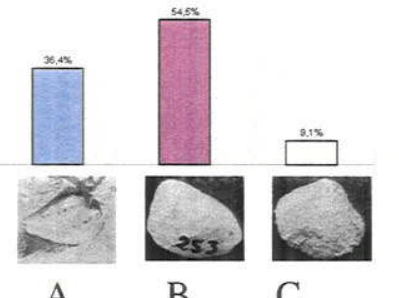

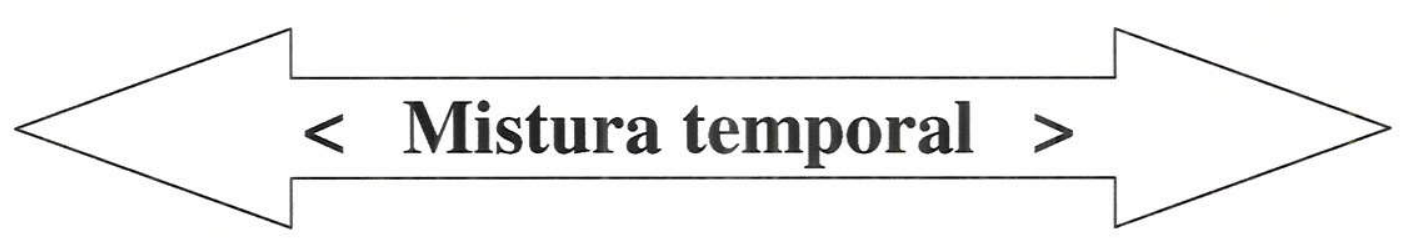

Figura 29. Frequiência dos três morfotipos (A, B e C) nas quatro concentrações fossilíferas estudadas e a relação com a mistura temporal. 


\subsection{RETROALIMENTAÇÃO TAFONÔMICA E MISTURA TEMPORAL EM CONCENTRAÇÕES FOSSILÍFERAS GERADAS POR TEMPESTADES.}

O termo retroalimentação tafonômica ("taphonomic feedback") foi proposto por Kidwell e Jablonski (1983) e refere-se à interação de organismos mortos e vivos, no qual organismos vivos reagem à presença de partes duras esqueléticas no habitat bentônico. $\mathrm{O}$ acúmulo de partes duras pode ocorrer tanto instantaneamente como gradualmente, devido aos mecanismos autogênicos (e.g., produtividade biológica local) ou alogênicos (e.g., transporte de bioclastos por correntes), responsáveis pela transformação do substrato originalmente mole, instável, em substrato duro (Kidwell e Jablonski, 1983; Kidwell, 1986a, 1991).

O mecanismo autogênico de acumulação consiste na resposta da comunidade inicial ao acúmulo gradual de suas próprias partes duras, que darão origem a uma acumulação esquelética constituída por partes duras de indivíduos mortos. Já o mecanismo alogênico reflete a atuação de processos físicos episódicos, capazes de remobilizar e transportar lateralmente partículas bioclásticas, para locais, especialmente da plataforma, onde o substrato não é originalmente rico em partículas biogênicas. Os eventos de tempestade destacam-se como os principais agentes desse processo (Kidwell, 1986b).

A cobertura do fundo por bioclastos favorece o desenvolvimento de espécies adaptadas a este tipo de conição, inibindo, ao mesmo tempo, a presença de espécies características de substratos moles, inconsolidados. Além do substrato duro oferecer condições para a colonização por organismos epibentônicos, ele é também utilizado como domicílio para certas espécies, abrigo contra o estresse, refúgio contra predadores e competidores e fixação de larvas (Kidwell, 1991).

Do ponto de vista tafonômico, entretanto, a retroalimentação tafonômica raramente é discernivel e fica preservada, uma vez que, repetidos eventos de tempestades tendem a destruir ou obliterar a sucessão ecológica de uma dada população de organismos bentônicos. Entretanto, sob condições muito especiais (Miller et al., 1988; Simões et al., 1998a,b, submetido), resultantes de variações do nível de base das ondas 
de tempestades, no ambiente plataformal, há possibilidade de preservação de animais em nítida configuração de retroalimentação tafonômica. Do ponto de vista paleoecológico e estratigráfico, a questão mais interessante relacionada ao processo de retroalimentação tafonômica diz respeito ao tempo de colonização ou recolonização dos diferentes tipos de substratos (e.g., mole versus duro). Tal fato deve-se a que, normalmente, para que o processo de retroalimentação tafonômica fique preservado no registro geológico há necessidade de soterramento abrupto. A questão, porém, é que apesar do soterramento abrupto, a definição temporal destas acumulações é altamente variável, porque a recolonização ou transformação do substrato não é instantânea, em termos ecológicos (Simões et al., 1998a,b). Desta forma, não existem, com relação a concentrações fósseis medidas temporais precisas do processo de retroalimentação tafonômica. Para solucionar esta questão, uma alternativa plausível é analisar o desenvolvimento de comunidades bentônicas marinhas atuais, especialmente as que foram perturbadas, por processos naturais (e.g., tempestades) ou artificiais (e.g., acidentes ecológicos) e examinar o tempo de recomposição ou recolonização do substrato bentônico. Precisa ficar claro, entretanto, que isso apenas fornece uma idéia muito geral do processo, uma vez que diferenças no comportamento, fisiologia, e pressões seletivas etc., não atuam de forma similar produzindo respostas semelhantes em todos os organismos marinhos.

$\mathrm{Na}$ natureza, diversos distúrbios de diferentes intensidades ocorrem nas comunidades bentônicas, envolvendo, especialmente, variações de temperatura, mudanças de estações, eventos de tempestades e terremotos. Dentre os fenômenos artificias, os efeitos de derramamentos de óleo sobre comunidades bentônicas foram intensivamente analisados. No geral, o que se observa é que o tempo de recolonização de um substrato afetado por distúrbios de qualquer natureza pode variar muito.

Um clássico exemplo de estudo de recolonização, após grande impacto ambiental foi realizado no Alasca, após o grande derramamento de óleo causado, em 1989, pelo cargueiro Exxon Valdez, que afetou a população de organismos marinhos costeiros do Golfo de Prince William. No caso dos bivalves da infauna, estudos anteriores ao derramamento de óleo, datam de 1971, período em que estes animais se recuperavam de alterações causadas pelo grande terremoto "Good Friday", em 1964 (Feder e Jawett, 1988 in Shiginaka, 1997). A abundância de bivalves da infauna (e.g., Nuculana fossa e 
Axinopsida veridis) aumentou entre 1971 e 1976-77 e só se estabilizou em 1985, ou seja, 21 anos após o terremoto. Em 1989, ocorreu o grande derramamento de óleo e, desta maneira, outros bivalves (Protothaca staminea e Saxidomus giganteus) foram monitorados. A abundância destes animais aumentou até 1992, havendo um declínio, em 1993 e 1994. Não existem, ainda, dados sobre a possível estabilização da fauna bentônica (Shiginaka, 1997), o que provavelmente só ocorrerá daqui a pelo menos 20 anos.

No caso da epifauna bissada, estudos envolvendo o tempo de colonização de substratos, principalmente em ambiente intermaré, são comuns (Seed e Suchaneck, 1980; Paine e Levin, 1981), uma vez que algumas espécies possuem interesse econômico. Os autores têm relatado tempos de colonização do substrato variáveis, provavelmente em razão da utilização de diferentes espécies, de condições ambientais e, principalmente, do tempo dispensado na análise. De acordo com Seed e Suchaneck (1980), a recolonização inicial do substrato leva de 20 a 26 meses, a partir do distúrbio inicial, sendo que 36 meses depois, $80 \%$ do substrato encontra-se colonizado e, em apenas 80 meses $(\sim 6,5$ anos) $100 \%$ do substrato mostra-se completamente colonizado. Paine e Levin (1981) apresentaram dados interessantes com relação à recolonização de substrato duro por Mytilus californianus e demonstraram que, em áreas dominadas por estes animais, o período de rotação, ou seja o período que uma comunidade afetada por um distúrbio leva até atingir a condição ideal, varia de 8 a 35 anos, dependendo da sua localização.

Outro estudo envolvendo a colonização de substrato horizontal, também por Mytilus californiamus, foi realizado, durante 16 anos, por Suchaneck e Duggins (in Seed e Suchaneck, 1980). O local de estudo, Shi-Shi, Washington, foi previamente limpo, através de método de raspagem e a colonização observada. Uma vez que o tempo de colonização mostrou-se bastante lento, um teste matemático foi utilizado, cujo resultado demonstra que o provável intervalo de tempo para o recobrimento do local poderia ser de $600 \pm 1139$ anos. Os autores alertam para o fato de que a recolonização pode realmente não levar este tempo, no caso de recrutamento larval repentino produzir uma aceleração do processo.

Desta maneira, o tempo envolvido na retroalimentação tafonômica de uma concentração fossilífera, pode variar muito, de 10 meses (tempo de desenvolvimento de 
um elemento da epifauna bissada) a $600 \pm 1139$ anos, dependendo da disponibilidade de larvas para recolonização, aspectos ambientais, temperatura da água e outros fatores naturais. $O$ tempo que a nova fauna provavelmente levará até se estabilizar, considerando as evidências disponíveis na literatura, é de aproximadamente 20 anos.

Um fator importante relacionado à ocorrência da retroalimentação tafonômica diz respeito à taxa de sedimentação, que deve ser muito baixa ou ausente, no caso de colonização de substrato duro e estável por epifauna (Kidwell e Jablonski, 1983; Kidwell, 1986b; Simões, 1998). Neste caso, os bioclastos constituintes do substrato duro apresentam-se em sua maioria desarticulados e em grande parte fragmentados (Kidwell, 1991).

Elementos pertencentes a epifauna somente se preservam em bom estado, com as valvas articuladas fechadas, se um soterramento rápido e imediato ocorrer (Simões, et al., submetido). Porém, na maioria das vezes, o sedimento depositado é temporário e rapidamente removido por retrabalhamento posterior (Seilacher, 1985; Miller et al., 1988; Kidwell, 1991; Simões et al., submetido). Quando isso ocorre, os colonizadores do substrato existentes antes do soterramento serão desarticulados, reorientados, e fragmentados, durante o novo ciclo de retrabalhamento, e incorporados ao substrato duro, previamente existente, conforme já referido no caso da gênese da concentração $C$, aqui descrita. Desta maneira, um novo ciclo de retroalimentação tafonômica, tendo como substrato o material esquelético depositado, ocorre em função da ausência de camada de sedimento fino que foi retrabalhada (Miller et al., 1988; Kondo e Kikuchi, 1995).

A superposição de sucessivas camadas fossilíferas ou amalgamação ocorre quando eventos de retrabalhamento removem a camada de sedimentos finos e superficies de substrato duro, previamente soterradas, são expostos e recolonizados (Seilacher, 1985; Miller et al., 1988), produzindo a mistura de duas ou mais comunidades. Esta sucessão de eventos foi descrita por Seilacher (1985) em acumulação esquelética gerada por tempestades no litoral da Malásia, nos últimos 60 anos. $\mathrm{O}$ autor acompanhou por 6 anos os processos de soterramento e retrabalhamento, reconhecendo diversos episódios de colonização de substrato duro (retroalimentação tafonômica) e soterramento por sedimento fino, originando assim uma concentração amalgamada (Fig. 30). Simões e 


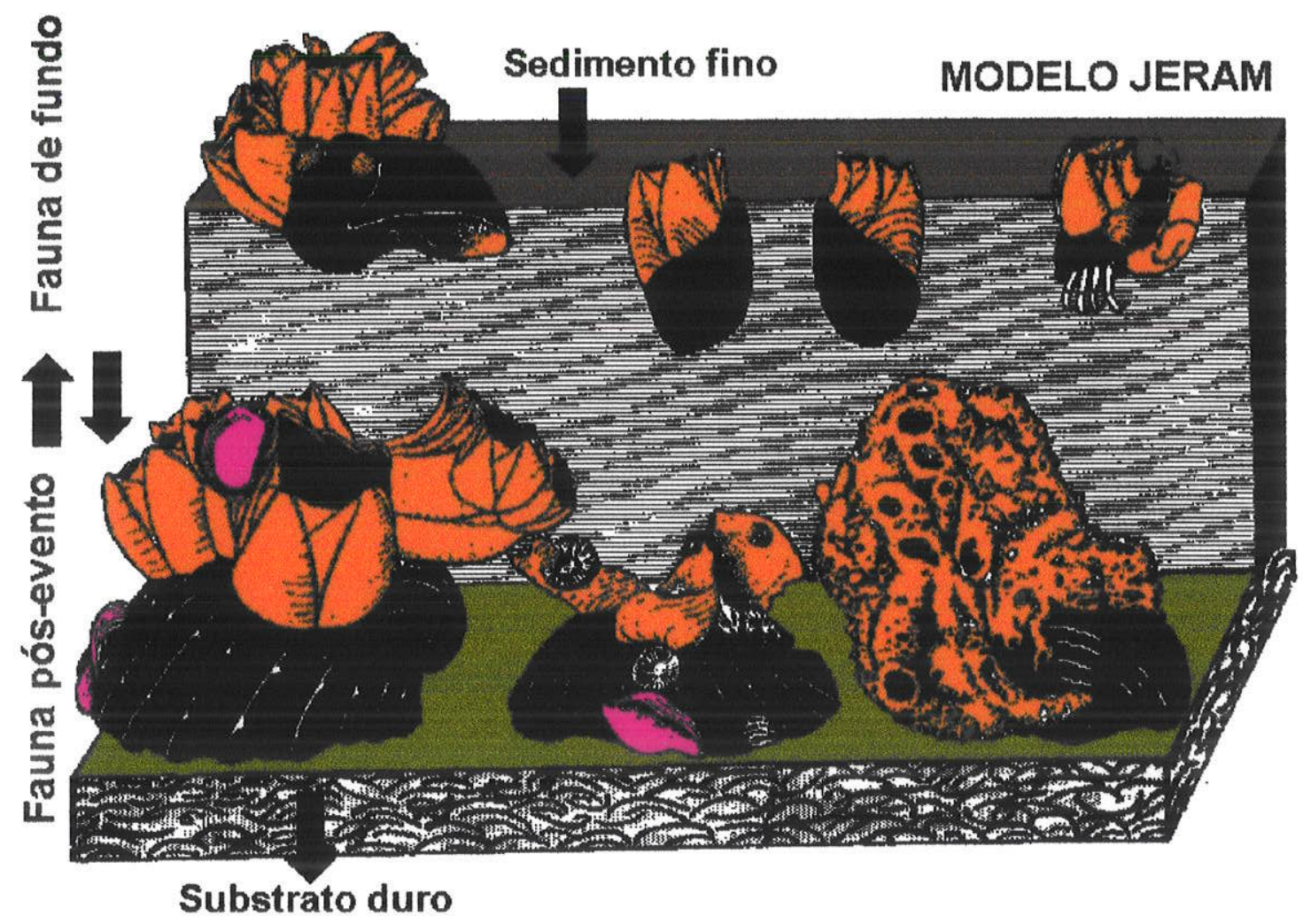

Figura 30. Processos de retroalimentação tafonômica decorrente de sucessivos eventos concentradores de material bioclástico em ambiente de planície de maré (litoral de Jeram, Malásia). Modificado de Seilacher (1985).

Kowalewski (1998a; p.190) chamaram a atenção para possibilidade deste processo ter ocorrido durante a gênese de arenitos bioclásticos da porção média da Formação Corumbataí. Nestes depósitos, entretanto, diferentemente do que ocorreu com a concentração fossilífera $\mathrm{C}$, os diferentes episódios de soterramento e retrabalhamento (Simões e Kowalewski, 1998a, Fig.13) obliteraram o registro, dificultando seu reconhecimento.

Segundo Miller et al. (1988), concentrações fossilíferas amalgamadas e repetidamente retrabalhadas freqüentemente apresentam, no seu topo, uma assembléia preservada in situ, refletindo o soterramento catastrófico final, o qual não foi removido por evento de tempestade posterior. Na maior parte dos casos, isso decorre de mudança 
da base das ondas normais e de tempestade. Devido a superposição de diversos processos de colonização do substrato, evidenciado pela mistura de conchas de formas da infauna com elementos da epifauna, desarticuladas e articuladas, preservadas em posição de vida, o grau de mistura temporal desta concentração deve ser alto.

Kidwell (1986b) analisou a mistura temporal em concentrações fossiliferas onde o grau de empacotamento varia devido a mudanças na taxa de sedimentação, e examinando ainda a presença de elementos adaptados a substratos consolidados. Quatro tipos de concentrações fossiliferas foram reconhecidos, de acordo com a natureza de seus contatos (Fig. 31). Nota-se na Figura 33, que nos tipos I e II, a transformação de um substrato inicial mole em substrato duro. Esta mudança traz alterações na estrutura da comunidade vivente, já que a presença de substrato duro favorece a colonização pela epifauna bentônica e inibe a presença de elementos da infauna, adaptada a substratos moles, caracterizando o processo de retroalimentação tafonômica (Kidweil e Jablonski,1983). O grau de mistura temporal conseqüentemente aumenta em direção ao topo da concentração fossilífera.

No caso dos tipos III e IV (Fig.32), a retroalimentação tafonômica é responsável pela manutenção da acumulação esquelética somente no início da concentração de partes duras. $\mathrm{O}$ aumento na taxa de sedimentação faz com que a ocorrência do processo de retroalimentação diminua em direção ao topo da concentração, diminuindo também o grau de mistura temporal. 


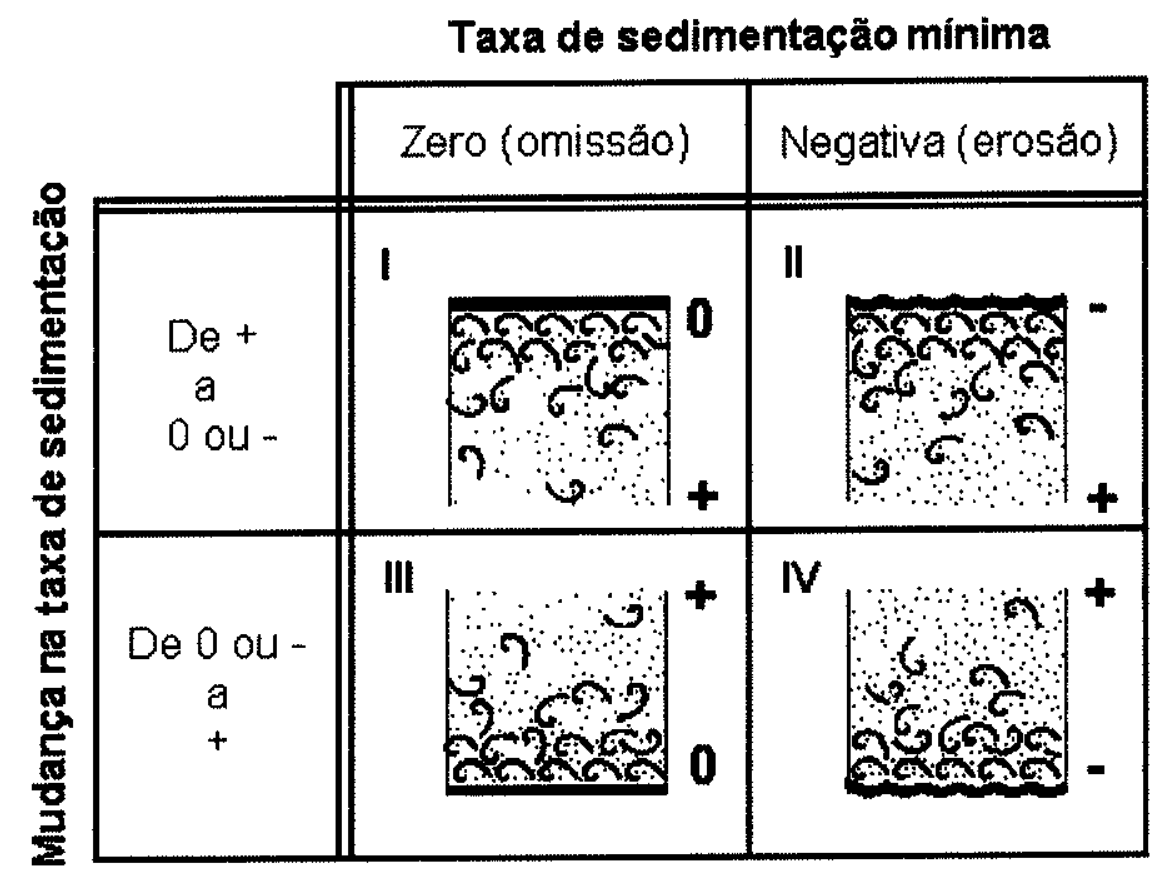

Figura 31. Tipos de concentraçōes fossilíferas propostas por Kidwell (1986b), de acordo com a natureza dos contatos superior e inferior. (modificado de Kidwell, 1986b) 


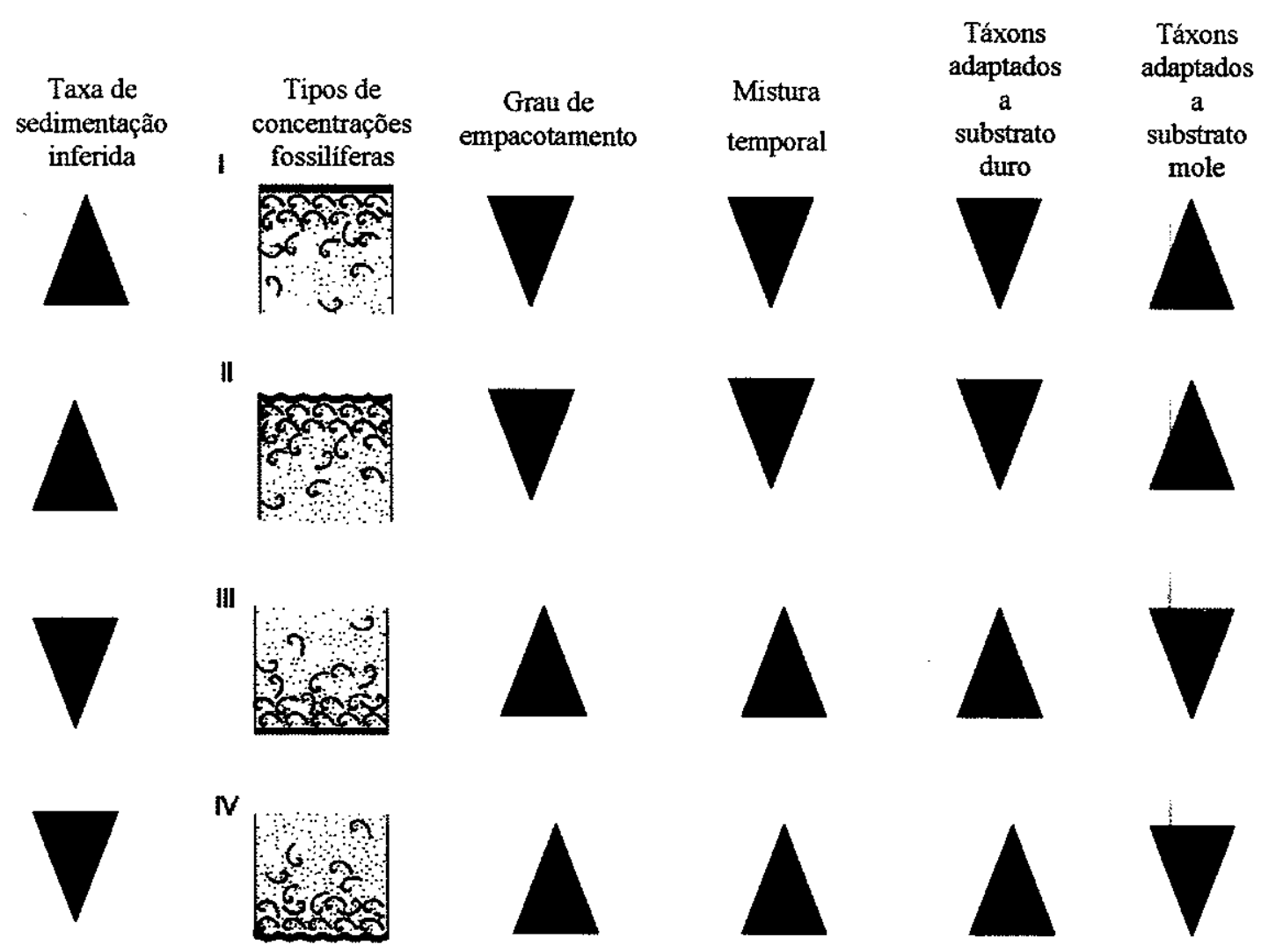

Figura 32. Diferença do grau de empacotamento nos quatro tipos de concertrações fossiliferas propostas por Kidwell (1986b) e suas consequeências no grau de mistura temporal e presença de táxons adaptados a substrato mole e duro (modificado de Kidwell, 1986b). 
Pode-se concluir, portanto, que quando o processo de retroalimentação tafonômica ocorre, devido a processos alogênicos (e.g., tempestades), o grau de mistura temporal desta concentração fossilífera é geralmente alto. De fato, se for considerado este aspecto e o tempo de colonização, acima discutido, observa-se que a "despeito do rápido soterramento, e de conterem organismos em posição de vida, estas acumulações esqueléticas são um registro condensado, com baixa definição temporal, mais do que o registro instantâneo (e.g., horas e dias) de comunidades marinhas betônicas" (Simões et al., 1998a,b, submetido). Esses mesmos autores foram os primeiros a constatar a ocorrência de retroalimentação tafonômica em acumulações esqueléticas do Paleozóico da Bacia do Paraná, nas formações Ponta Grossa (Devoniano) e Corumbataí (Permiano superior). O exemplo abaixo discutido está, em parte, fundamentado nas observações desses autores, e refere-se a concentração $C$, já descrita neste trabalho.

A concentração $\mathrm{C}$ constitui um excelente exemplo de retroalimentação tafonômica. Apresenta ela contato basal erosivo com o siltito subjacente e contato superior brusco e ondulado também com siltito, estendendo-se lateralmente por, pelo menos, 8 metros. $\mathrm{O}$ grau de empacotamento dos bioclastos varia de denso a disperso, em matriz argilosa, aumentando em direção ao topo da concentração. Os fósseis estão arranjados caoticamente na matriz, onde ocorrem bioclastos aninhados ou empilhados. Dentre as espécies presentes, destacamse Cowperesia anceps, Jacquesia brasiliensis, Holdhausiella elongata e Naiadopsis lamellosus. Conchas desta última ocorrem tanto desarticuladas como articuladas fechadas, algumas em posição de vida (Fig. 33). Naiadopsis lamellosus pertence à semi-infauna bissada, suspensivora (Ghilardi et al., 1995). Deste modo, o acúmulo de partes duras, originando um substrato estável, favoreceu a sua fixação. $O$ substrato duro é constituído por bioclastos fragmentados, desarticulados incluindo conchas de Naiadopsis lamellosus, de diferentes tamanhos $(1-8 \mathrm{~cm})$, inteiras ou fragmentadas, com ou sem sinais de abrasão. Estas características sugerem a ocorrência de vários episódios de colonização e retrabalhamento e de diversos processos de retroalimentação tafonômica. A mistura de conchas de bivalves da infauna com as de elementos da epifauna bissada, ambas em diversos estados de preservação, indica alto grau de mistura temporal. 


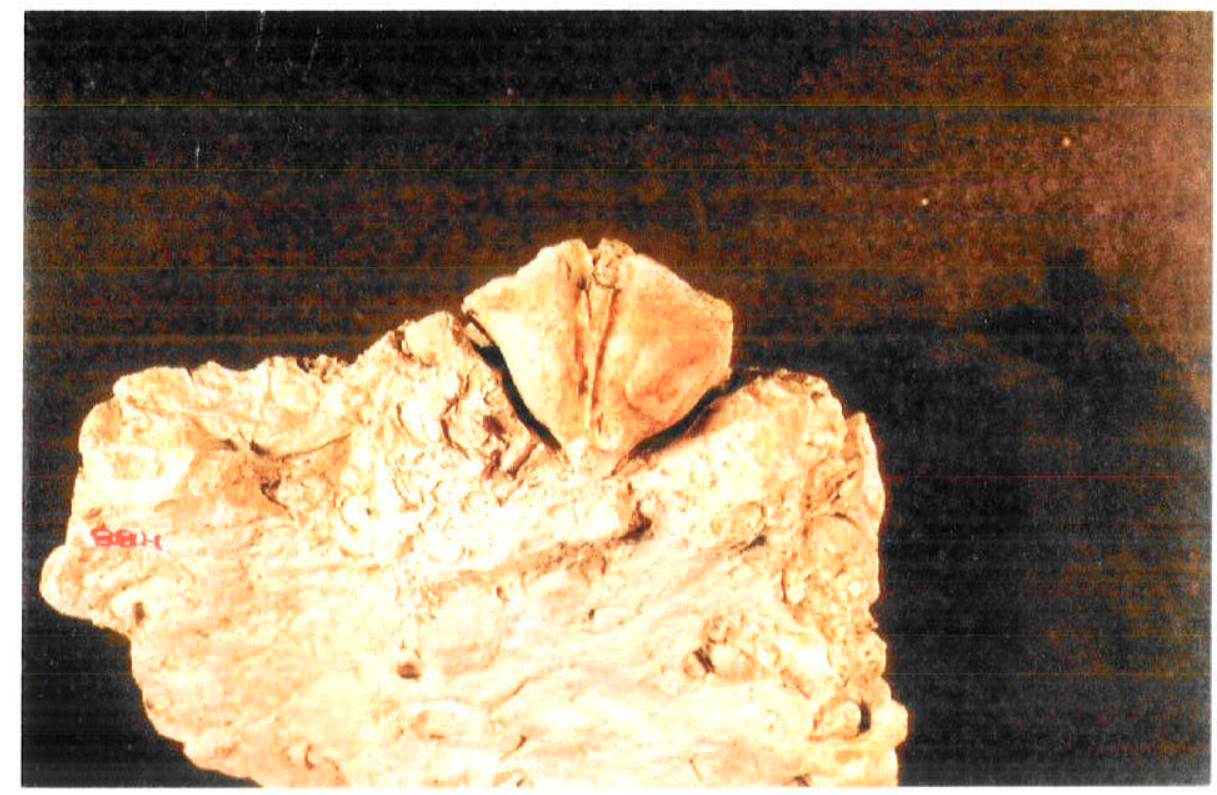

Figura 33. Aspecto geral de concha de Naiadopsis lamellosus, elemento da semi infauna bissada, presente no topo da concentração fossilífera 3, preservada em posição de vida (in situ).

A constatação, de retroalimentação tafonômica na concentração C só foi possível devido à preservação de elementos da semi-infauna bissada em posição de vida, no topo da concentração fossilífera. A preservação resultou do soterramento brusco, indicado pelo depósito de sedimento fino, que recobre a acumulação esquelética, associado a eventos de tempestade. A preservação só foi possível em decorrência da alteração do nível de base das ondas de tempestade, que evita que conchas preservadas no topo da acumulação esquelética sejam retrabalhadas por eventos subsequentes similares. Entretanto, a presença de conchas de Naiadopsis lamellosus desarticuladas, no interior da concentração, a variação no grau de empacotamento dos bioclastos e a enorme heterogeneidade na qualidade de preservação das conchas dos bivalves são excelentes indicadores da gênese complexa desta acumulação esquelética e de sua limitada definição temporal. 


\section{CONCLUSÕES}

1. Sedimentos da parte superior da Formação Corumbataí, na região de Tambaú, contém 4 ocorrências fossilíferas novas;

2. Todas as ocorrências correspondem a concentrações esqueléticas dominadas por conchas de bivalves;

3. O estudo tafonômico destas concentrações revelou que as mesmas foram geradas por eventos de tempestade;

4. Nas concentrações fossiliferas A e B foi possivel investigar a natureza complexa da acumulação esquelética, identificando processos de fundo e episódicos;

5. As concentrações fossiliferas A e B foram provavelmente depositadas abaixo da base das ondas de tempestades, pois apresentam baixa proporção de conchas fragmentadas, alto índice de conchas articuladas e alta proporção de matriz, representando um tempestito distal;

6. A concentração fossilifera $\mathrm{C}$ corresponde a um tempestito distal depositado abaixo da base das ondas de tempestade e tendo sido preservado devido a mudança do nível de base das ondas normais e de tempestade;

7. A concentração fossilifera $\mathrm{C}$ inclui Naiadopsis lamellosus, bivalve da semi infauna bissada, preservado em posição de vida, o que indica processo de retroaiimentação tafonômica e possível colonização dos bioclastos previamente acumulados;

8. A presença de mistura de conchas articuladas fechadas e desarticuladas, de Naiadopsis lamellosus em diversos estados de preservação, na concentração fossilífera $\mathrm{C}$, indica a ocorrência de vários eventos de colonização de substrato duro 
e estável formado por conchas de bivalves e retrabalhamento posterior deste substrato por eventos de alta energia;

9. A natureza dispersa da concentração fossilifera $D$, sugere não ter havido seleção granulométrica da matriz, e curto o período de tempo de atuação dos processos de erosão, retrabalhamento e seleção durante o evento episódico;

10. Na concentração fossilifera $\mathrm{D}$, houve seleção de valvas direitas e esquerdas, o que revela a intensidade dos processos que atuaram no ambiente de origem dos bioclastos (processos tafonômicos de fundo), uma vez que 100\% das valvas encontram-se também desarticuladas. Representa um tempestito proximal.

11. Em todos os casos, pôde-se notar a mistura de organismos de diferentes modos de vida e diferentes estados de preservação, o que sugere que todas as concentrações fossiliferas apresentam certo grau de mistura temporal;

12. A análise de diversas concentrações fossiliferas do Grupo Passa Dois, incluindo as concentrações fossiliferas A, B e C, revelou que conchas de Pinzonella neotropica, apresentam 3 morfotipos distintos. Nas concentrações fossiliferas com maior grau de mistura temporal ocorrem 3 morfotipos em proporções semelhantes. Desta maneira, a presença destes 3 morfotipos em uma mesma concentração fossilífera é indicativa de alto grau de mistura temporal;

13. O estudo realizado permitiu elaborar um modelo de tafofacies, para o Grupo Passa Dois (Permiano) na Bacia do Paraná, em complementação ao modelo de Simões (1996a). O modelo distingue 5 tafofacies ao longo do gradiente de águas rasas e profundas, incluindo as concentrações fossilíferas de Tambaú, assim como outras concentrações fossilíferas das formações Serra Alta e Terezina e Corumbataí. 


\section{BIBLIOGRAFLA}

AIGNER, T. (1982) Event-stratification in nummulite accumulations and in shell beds from the Eocene of Egypt. In: EINSELE, G.; SEILACHER, A. (eds.) Cyclic and Event Stratification, Springer, p. 248-262.

AIGNER, T. (1985) Storm depositional systems. Lecture Notes in Earth Sciences, v. 3, p. 1-174.

AIGNER, T.; HAGDORN, H.; MUNDLOS, R. (1978) Biohermal, biostromal and storm-generated coquinas in the Upper Muschelkalk. Neues Jahrbuch für Geologie und Paläontologie Abhandlungen, $v$. 157, p. 42-52.

ALLISON, P.A.; BRIGGS, D.E.G. (1991) Taphonomy: releasing the data locked in the fossil record. Plenum Press. 560p.

ALLMON, R.A. (1985) "Butterflied" bivalves as paleoenvironmental indicators. In: GEOLOGICAL SOCIETY OF AMERICA, Abstract with Program. v. 17, p. 512.

BANERJEE, I.; KIDWELL, S.M. (1991) Significance of molluscan shell beds in sequence stratigraphy: example from the Lower Cretaceous Mannville Group of Canada. Sedimentology, v. 38, p. 913-934.

BRENCHLEY, P.J.; HARPER, D.A.T. (1998)

Palaeoecology: ecosystems, environments and evolution. Chapmann \& Hall, 402p.

\author{
BRETT, C.E. (1995) Sequence \\ stratigraphy, bioestratigraphy and \\ taphonomy in shallow marine \\ environments. Palaeogeography, \\ Palaeoclimatology, \\ Palaeoecology, v. 10, p. 597-616.
}

BRETT, C.E.; EAIRD, G.C. (1986) Comparative taphonomy: a key to paleoenvironmental interpretation based on fossil preservation. Palaios, v. 4, p. 303-309.

BRETT, C.E.; BAIRD, G.C. (1991) Submarine erosion on the anoxic seafloor: stratinomic paleoenvironmental and temporal significance of reworked pyrite-bone deposits. In: TYSON, R.V.; PEARSON, T.H. (eds.) Modern and ancient continental shelf anoxia. Geological Society Special Publication, n. 58, p. 233-258.

BRETT, C.E.; BAIRD, G.C.

Taphonomic approaches to temporal resolution in stratigraphy: examples from Paleozoic marine mudrocks. In: KIDWELL, S.M.; BEHRENSMEYER, A.K. (eds.) Taphonomic approaches to time resolution in fossil assemblages, Short Course in Paleontology, n. 6, p. 250-274.

BRETT, C.E.; BAIRD, G.C. (1997) Epiboles, outages and ecological evolutionary bioevents: taphonomy, ecology and biogeographic factors. In: BRETT, C.E.; BAIRD, G.C. (eds.) Paleontologic Events: 
Stratigraphic, Ecologic, and Evolutionary Implications. New York, Columbia University Press, p. 249-284.

BRETT, C.E; SEILACHER, A. (1991) Fossil Lagerstätten: a taphonomic consequence of event sedimentation. In: EINSELE, G.; RICKEN, W.; SEILACHER, A. (eds) Cycles and event in stratigraphy. Berlim, Springer Verlag, p. 3-40.

BRETT, C.E.; SPEYER, S.E.; BAIRD,G.C. (1986) Storm-generated sedimentary units: tempestite proximality and event stratification in the Middle Devonian Hamilton Group of New York. In: BRETT, C.E. (ed.) Dynamic Stratigraphy and depositional enviroments of the Hamilton Group (Middle Devonian) in Now York State, Part 1: New York State Museum Bulletin, v. 457, p. 129-156. BRETT, C.E.; BAIRD, G.C.; SPEYER, S.E. (1997) Fossil Lagerstätten: stratigraphic record of paleontological and taphonomical events. In: BRETT, C.E; BAIRD, G.C. (eds.) Paleontologic Events: Stratigraphic, Ecologic, and Evolutionary Implications. New York, Columbia University Press, $p$. 3-40.

CLIFTON, H.E.; BOGGS JR, S. (1970) Concave-up pelecypod (Psephidia) shells in shallow marine sand, Elk River beds, Southwestern Oregon.
Journal of Sedimentary Petrology, v. 40, p. $888-897$.

DAEMON, R.F.; QUADROS, L.P. (1970) Bioestratigrafía do Neopaleozóico da Bacia do Paraná. In: CONGRESSO BRASILEIRO DE GEOLOGIA, 24., Rio de Janeiro, 1970. Anais. Rio de Janeiro, p. 359-412.

DALPONTE, J.C.; GONÇALVES, N.M.M. (1979) Contribuição ao estudo da Formação Estrada Nova (P) na regiăo de Tambaú, SP. Ciéncia e Cultura, v. 31, n. 7, p. 759-771.

DAVIES, D.J.; POWELL, E.N.; STANTON, R.J., Jr. (1989) Taphonomic signature as a function of environmental process: shells and shell beds in a hurricane-influenced inlet on the Texas coast.

Palaeogeography,

Palaeoclimatology,

Palaeoecology, v. 72, p. 317-356.

DONAVAN, S.K. (1991) The process of fossilization. Columbia Univ. Press, New York. 303p.

EYLES, N.; LAGOE, M.B.

(1989)

Sedimentology of shell-rich deposits (coquinas) in the glaciomarine upper Cenozoic Yakataga Formation, Middleton Island, Alaska. Geological Society of America Bulletin, v. 101, p. 129-142.

FAGERSTROM, J. (1964) Fossil communities in paleoecology: their recognition and significance. Geological Society of America Bulletim, v. 75, p. 1197-1296. 
FLESSA, K.W. (1998) The well-traveled cockes: shell transport during the Holocene transgression of the southern North Sea. Geology, v. 26, p. $187-190$.

FLESSA, K.W.; KOWALEWSKI, M. (1994) Shell survival and time-averaging in nearshore and shelf environments: estimatives from the radiocarbon literature. Lethaia, v. 27, p. 153-165. FLESSA, K.W.; CUTLER, A.H.; MELDAHL, K. (1993) Time and taphonomy: Quantitative estimates of timeaveraging and stratigraphic disorder in a shallow marine habitat. Paleobiology, v. 19, p. 266-286.

FOLLLMI, K.B.; GARRISON, R.E.; GRIMM, K.A. (1991) Stratification in phosphatis sediments: illustrations from the Neogene of California. In: EINSELE, G; RICKEN, W.; SEILACHER, A. (eds.) Cycles and events in stratigraphy. Spring Verlag, Berlim, p. 492-507.

FÜRSICH, F.T. (1982) Rhythmic bedding and shell-bed formation in the Upper Jurassic of east Geenland. In: EINSELE, G; SEILACHER, A. (eds.) Cyclic and Event Stratification. Springer-Verlag, Berlim, p. 208-222.

FÜRSICH, F.T. (1990) Fossil concentrations and life and death assemblages. In: BRIGGS, D.E.; CROWTER, P.R. (eds.) Palaeobiology. Blackwell Science, p. 235-239.
FURSICH, F.T. ; ABERHAN, M. (1990) Significance of time-averaging for paleocommunity analysis. Lethaia, v. 23, p. $143-152$.

FÜRSICH, F.T.; KIRKLAND, J.l. (1986) Bioestratinomy and paleoecology of a Cretaceous brackish lagoon. Palaios, v. 1, p. 543-560.

FÜRSICH, F.T.; OSCHMANN, W. (1986) Storm shell beds of Nanogyra virgula in the Upper Jurrassic of France. Neues Jahrbuch für Geologie und Palăontologie Abhandlungen, $v$. 172, p. 141-161.

FÜRSICH, F.T.; OSCHMANN, W. (1993) Storm shell beds as tools in basin analysis: the Jurassic of Kachohh, western India. Journal of Geological Society of London, v. 150, p. 169-185.

FUTTERER, E. (1982) Experiments on the distinction of wave and currentinfluenced shell accumulation. In: EINSELE, G.; SEILACHER, A. (eds.), Cyclic and event stratification, Springer-Verlag, Berlim, p. 175-179. R.P. (1999) Paleoautoecologia dos bivalves do Grupo Passa Dois (Neopermiano) no Estado de Săo Paulo: bivalves fósseis como indicadores da dinâmica sedimentar. São Paulo. (Dissertação-Mestrado) - Instituto de Geociências, Universidade de São Paulo, 160p. 
GHILARDI, R.P.; TORELLO, F.F.; MELLO, L.H.C.; SIMÓES, M.G. (1995) O significado paleoecológico de Naiadopsis lamellosus Mendes, Formação Corumbataí (Neopermiano), Bacia do Paraná, Brasil. In: CONGRESSO DE INICIAÇÃO CIENTIFICA DA UNESP, 10., Guaratinguetá, 1995. Resumos. Guaratinguetá, p. 53.

GHILARDI, R.P.; SIMŐES, M.G.; MELLO, L.H.C.; TORELLO, F.F. (1997) The oldest occurrence of pelecypods shells in Corumbatai Formation (Late Permian), Paraná Basin, Brazil. In: CONGRESSO BRASILEIRO DE PALEONTOLOGIA, 15, São Pedro, 1997. Boletim de Resumos. São Pedro, p. 64.

GOODFRIEND,

G.A.

(1987)

Chronostratigrafic studies of sediments in the Negav Desert, using amino acid epimerization analysis of land snails. Quatemary Research, v. 28, p. 374-392.

GOODFRIEND, G.A (1989)

Complementary use of amino acid epimerization and radiocarbon analisys for dating mixed-age fossil assemblage. Radiocarbon, v. 31, p. 1041-1047.

GOODFRIEND, G.A.; FLESSA, K.W. (1997) Radiocarbon reservoir ages in the Gulf of California: role of upwelling and flow from the Colorado River, Radiocarbon, v. 39, p. 139148.
GOODFRIEND, G.A.; GOULD, S.J. (1996) Paleontology and cronology of an evolutionary transition by hybridization in the Bahamian land snail Cerion. Science, v. $274, p$. 1894-1897.

GOODFRIEND, G.A.; FLESSA, K.W.; KOWALEWSKI, M. (1995) Age distribution of bivalve shells in cheniers and the late Holocene environmental history of Colorado Delta. Geological Society of America Abstracts with Program, v. 27, p. $A 373$.

GOODFRIEND, G.A.; FLESSA, K.W.; HARE, P.E. (1997) Variation in amino acid apimerization rates and amino acid composition among shell layers in the bivalve Chione from the Gulf of California. Geochimica et Cosmochimica Acta, v. 61 , p. 14871493.

IPT (1981) Mapa geológico do Estado de Săo Paulo. Instituto de Pesquisas Tecnológicas do Estado de São Paulo.

JOHNSON, R.G. (1960) Model and methods for analysis of the mode of formation of fossil assemblages. Geological Society of America Bulletin, v. 71, p. 1075-1086.

KELLING, N.; WILLIANS, N. (1967) Flume studies of orientation of peebles and shells. Journal of Geology, v. 75, p. 245-267.

KIDWELL, S.M. (1985) Palaeobiological and sedimentological implications of 
shell concentrations. Nature, v. $318, p .457-460$.

KIDWELL, S.M. (1986a) Taphonomic feedback in Miocene assemblages: testing the role of dead hard parts in benthic communities. Palaios, v. 1 , p. 239-255.

KIDWELL, S. M. (1986b) Models for fossil concentrations: Paleobiologic implications. Paleobiology, v.12, p. 6-24.

KIDWELL, S.M. (1991) The stratigraphic condensation of marine transgressive records: origin of major shell deposits in miocene of Maryland. Journal of Geology, $v$. 97, n. 1, p. 1-24.

KIDWELL, S.M.; AIGNER, T. (1985) Sedimentary dynamics of complex shell beds: implications for ecological and evolutionary patterns. In: BAYER, U.; SEILACHER, A. (eds) Sedimentary and evolutionary cycles, Springer-Verlag, Berlim, p. 382-395.

KIDWELL, S.M.; BEHRENSMEYER, A.K. (1993) Taphonomic approaches to time resolution in fossil assemblages. Short Course in Paleontology, n. 6, 302p.

KIDWELL, S.M.; BRENCHELEY, J.P. (1994) Patterns in bioclastic accumulation through the Phanerozoic: changes in input or destruction? Geology, v. 22, p. 1139-1143.
KIDWELL, S.M.; BRENCHELEY, J.P. (1996) Evolution of the fossil record: thickness trends in marine skeletal accumulations and their implications. In: JABLONSKI, D.H.; ERWIN, D.H.; LIPPS, J.H. (eds.) Evolutionary Paleobiology. University of Chicago Press, p. 290-336.

KIDWELL, S.M.; BOSENCE, D.W.J. (1991) Taphonomy and time-averaging of marine shelly faunas. In: ALLISON, P.A.; BRIGGS, D.E.G. (eds.) Taphonomy: releasing the data locked in the fossil record. Plenum Press, p. 115-209.

KIDWELL, S.M.; FLESSA, K.W. (1995) The quality of fossil record: populations, species and communities. Annual Review of Ecological Systems, v. 26, p. 269-299.

KIDWELL, S.M.; HOLLAND, S.M. (1991) Field description of coarse bioclastic fabrics. Palaios, v. 6, p. 426-434.

KIDWELL, S.M.; JABLONSKY, D. (1983) Taphonomic feedback: ecological consequences of shell accumulation. In: TEVESZ, M.J.; MCCALL, P.L. (eds.) Biotic interactions in Recent and fossil benthic communities, Plenum Press, p. 195-248.

KIDWELL, S.M.; FÜRSICH, F.T.; AIGNER, T. (1986) Conceptual framework for the analysis of fossil concentrations. Palaios, v. 1, p. 228-238.

KLEIN, C. (1997) Contribuição ao estudo das concentrações fossiliferas do Grupo Passa Dois na regiåo de 
Tiarajú, RS e suas implicaçðes paleoambientais. $153 p$.

(Dissertação-Mestrado) - Centro de Ciências Tecnológicas, Universidade do Vale do Rio dos Sinos.

KLEIN, C.; LEIPNITZ, I...; SIMÕES, M.G.; NOWATZKI, C.H. (1997a) Concentraçăo fossilífera de pelecipodes da Formaçăo Terezina (Permiano Superior), Bacia do Paraná, na região de Tiarajú, RS, Brasil. In: CONGRESSO BRASILEIRO DE PALEONTOLOGIA, 15., São Pedro, 1997. Boletim de Resumos. São Pedro, p. 69.

KLEIN, C.; SIMŐES, M.G.; LEIPNITZ, I.I.; RICHTER, M. (1997b) Interpretação dos dados tafonómicos na deposição de peixes e pelecípodes da Formaçăo Terezina (Grupo Passa Dois), na região de Tiarajú, RS. In: CONGRESSO BRASILEIRO DE PALEONTOLOGIA, 15., São Pedro, 1997. Boletim de Resumos. Săo Pedro, p. 166.

KONDO, Y. (1997) Inferred bivalve response to rapid burial in a Pleistocene shallow-marine deposit from New Zealand.

Palaeogeography,Palaeoclimatolo gy, Palaeoecology, v. 128 , p. $87-$ 100.

KONDO, Y. (1998). Adaptive strategies of soft-bottom, suspension-feeding bivalves to physical disturbance: evidence from fossil preservation. In:
Johnston, P.A.; Haggart, J.W. (eds.) Bivalves - An Eon of evolution paleobiological studies honoring Norman D. Newell. Calgary, University of Calgary Press, p. 377 392.

KONDO, Y.; KIKUCHI, N. (1995) "Shelly softground" colonized by an endobyssate bivalve Modiolus kurulensis: an example of taphonomic feedback from the Pleistocene of Kanazawa, Japan. Transactions and proceedings of the paleontological society of Japan, New series, v. 180, p. $296-$ 302.

KOWALEWSKI, M. (1996) Time-averaging, overcompleteness, and the geological record. Journal of Geology, v. 104, p. 317-326.

KOWALEWSKI, M. (1998) Paleoecology. Mc Graw-Hill Yearbook of Science and Technology 200, p. $1-4$

KOWALEWSKI, M., FLESSA, K.W.; HALLMANN, D.P. (1995) Ternary taphograms: Triangular diagrams applied to taphonomic analysis. Palaios, v. 10 , p. 478-483.

KOWALEWSKI, M.; GOODFRIEND, G.A.; FLESSA, K.W. (1998) Highresolution estimates of temporal mixing within shell beds: the evils and virtues of time-averaging. Paleobiology, v. 24, p. 287-304.

LANDIM, P.M.B. (1970) O grupo Passa Dois (P) na Bacia do Rio Corumbataí. Boletim DNPM, 
Divisão de Geologia e Mineralogia, v. 252, p. $1-103$.

LOUTIT, T.S.; HÁRDENBOL, J.; VAIL, P.R.; BAUM, P. (1988) Condensed section: the key to age dating and correlation of continental margin sequences. In: WILGUS, C.K.; HASTINGS, B.S.S.C.; KENDAL, C.G.; POSAMENTIER, H.W.; ROSS, C.A.; VAN WAGONER, J.C. (eds.) Sea level changes - an integration approach. Society of economic paleontologists and mineralogists special publication, v. 42, p. 183-213. MARANHÃO, M.S.A.S.

Contribuiçăo ao conhecimento da malacofauna das camadas basais da Formaçăo Corumbataí (Permiano), Estado de Săo Paulo. São Paulo, 89p. (Dissertação de Mestrado) - Instituto de Geociéncias, Universidade de São Paulo.

MARANHÃO, M.S.A.S. (1995) Fósseis das formações Corumbataí e Estrada Nova do Estado de São Paulo: subsidios ao conhecimento paleontológico e bioestratigráfico. São Paulo, 2v. (Tese-Doutorado) Instituto de Geociéncias, Universidade de São Paulo.

MARANHÃO, M.S.A.S.; PETRI, S. (1997) Novas ocorrências de fósseis nas Formaçöes Corumbataí e Estrada Nova do Estado de São Paulo e considerações preliminares sobre seus significados paleontológico e bioestratigráfico. Revista do
Instituto Geologico. v. 12 , n. 1/2, p. 33-54.

MELDAHL, K.H. (1993) Geographic gradients in the formation of shell concentrations: Plio-Pleistocene marine deposits, Gulf of California. Palaeogeography,

Palaeoclimatology,

Palaeoecology, v. 101, p. 1-25.

MELDHAL, K.H.; FLESSA, K.W (1990) Taphonomic pathways and comparative biofacies and taphofacies in a recent intertidal/shallow shelf environment. Lethaia, 23: 43-60.

MELLO, L.H.C. (1999) Análise cladistica dos bivalves do Grupo Passa Dois (Neopermiano), Bacia do Paraná, Brasil: Implicaçőes taxonómicas, evolutivas e paleobiogeográficas. São Paulo, 160p. (DissertaçãoMestrado) - Instituto de Geociências, Universidade de São Paulo.

MELLO, L.H.C.; GHILARDI, R.P.; TORELLO, F.F. (1998) Some biostratinomic aspects of carbonate concretions from Serra Alta Formation (Late Permian), Paraná Basin, Brazil. In: Congresso Brasileiro de Geologia, 40., Belo Horizonte, 1998. Anais. Belo Horizonte, p. 452.

MENDES, J.C. (1952) A Formação Corumbatai na região do Rio Corumbataí (estratigrafia e descriçăo dos lamelibrânquios). Boletim da Faculdade de Filosofia, Ciéncias e 
Letras, 145, Geologia, v. 8, p. 1 119.

MENDES, J.C. (1962) Lamelibrânquios permianos do ólito de Angatuba, Estado de São Paulo (Formação Corumbatai). Boletim da Sociedade Brasileira de Geologia, v. 11, n. 1 , p. $37-56$.

MILLER, K.B. (1986) Depositional environments and sequences, "Pleurodictyum Zone", Ludlowville Formation of western New York. In: BRETT, C.E. (ed.) Dynamic Stratigraphy and Depositional Environments of the Hamilton Group (Middle Devonian) in New York State, Part 1. New York State Museum Bulletin, v. 457, p. 57-77.

MILLER, K.B.; BRETT, C.E.; PARSONS, K.M. (1988) The paleoecologic significance of storm-generated disturbance within a Middle Devonian muddy epeiric sea. Palaios, v. 3, p. 35-52.

NELSON, C.H. (1982) Modern shallowwater graded sand layers from storm surges, Bering Shelf: a mimic of Bouma sequences and turbidite systems. Journal of Sedimentary Petrology, v. 52, p. 537-545.

NORRIS, R.D. (1986) Taphonomic gradients in shelf fossil assemblage: Pliocene Purisima Formation, California. Palaios, v. 1, p. 256-270.

OLIVERA, A.M; WOOD, W.L. (1997) Hydrodynamis of bivalve shell entrainement. Journal of
Sedimentary Research, Section a, v. 67, p. $514-526$.

PAINE, R.T.; LEVIN, S.A. (1981) Irtertidal landscapes: disturbance and the dynamics of pattern. Ecological Monographs, v. 51, p. 145-178.

PARSONS, K.M; BRETT, C.E.; MILLER, K.B. (1988) Taphonomy and depositional dynamics of Devonian shell-rich mudstones.

Palaeogeography,

Palaeoclimatology, Paleoecology, v. 63, p. $139-153$.

PETERSON, C.H. (1985) Patterns of lagoonal bivalve mortality after heavy sedimentation and their paleoecological significance. Paleobiology, v. 11, n. 2, p. 139153.

PILKEY, O.H.; TRUMBULL, J.V.A.; BUSH, D.M. (1978) Equilibrium shelf sedimetation, Rio de la Plata shelf, Puerto Rico. Journal of Sedimetary Petrology, v. $48, p$. 389-400.

POSAMANTIER, H.W.; VAIL, P.R. (1988) Eustatic controls on clastic deposition II- Sequence and systems tract models. In: WILGUS, C.K.; HASTINGS, B.S.S.C.; KENDAL, C.G.; POSAMENTIER, H.W.; ROSS, C.A.; VAN WAGONER, J.C. (eds.) Sea level changes- an integration approach. Society of economic paleontologists and mineralogists 
special publication, v. 42, p. 125 154.

POSAMENTIER, H.W.; JERVEY, M.T.; VAIL, P.R. (1988) Eustatic controls on clastic deposition I- Conceptual framework. In: WILGUS, C.K.; HASTINGS, B.S.S.C.; KENDAL, C.G.; POSAMENTIER, H.W.; ROSS, C.A.; VAN WAGONER, J.C. (eds.) Sea level changes- an integration approach. Society of economic paleontologists and mineralogists special publication, $v$. 42, p. 109-124.

RAGONHA, E.W. (1980) Características físicas da zona de Pinzonella illusa e Plesiocyprinella carinata da Formação Corumbatai - Grupo Passa Dois, na região de Rio Claro (SP). In:

CONGRESSO BRASILEIRO DE GEOLOGIA, 21., Balneário de Camboriú, 1980. Anais. Balneário de Camboriú, $p$. 3106-3117.

ROHN, R. (1988) Bioestratigrafia e paleoambientes da Formaçáo Rio do Rasto na borda leste da Bacia do Paraná (Permiano Superior, Estado do Paraná). São Paulo, 225p. (Dissertação-Mestrado) Instituto de Geociéncias, Universidade de São Paulo.

ROHN, R. (1994) Evolução ambiental da Bacia do Paraná durante o Neopermiano no leste de Santa Catarina e do Paraná. São Paulo, 2v. (Tese-Doutorado) - Instituto de
Geociências, Universidade de São Paulo.

ROHN, R.; FAIRCHILD, T.R. (1986) Estromatólitos permianos em calcário coquinóide do Grupo Passa Dois, Nordeste do Paraná. Anais Academia Brasileira Ciéncias, v. 58, n. 3, p. $433-444$.

ROHN, R.; PENATTI, J.R.R. (1993) Bioestratinomia de moluscos bivalves da Formação Teresina (Bacia do Paraná, Permiano superior). In: CONGRESSO BRASILEIRO DE PALEONTOLOGIA, 13., São Leopoldo, 1993. Boletim de Resumos. Săo Leopoldo, p. 200. ROHN, R.; PERINOTO, J.A.J.; FÚLFARO, V.J.; SAAD, A.R.; SIMOESS, M.G. (1995) On the significance of Pinzonella neotropica assemblage (Upper Permian) for the Paraná Basin, Brazil. In: SIMPÓSIO SULBRASILEIRO DE GEOLOGIA, 6 ., ENCONTRO DE GEOLOGIA DO CONE SUL, 1, Rio Claro, 1995, Boletim de Resumos Expandidos, Rio Claro, p. 260-261.

RUNNEGAR, B. (1974) Evolutionary history of the bivalve Subclass Anomalodesmata. Journal of Paleontology, v. 48, n. 5 , p. $904-$ 939.

RUNNEGAR, B.; NEWELL, N.D. (1971) Caspian-like relict molluscan fauna in South American Permian. Bulletin 
of the American Museum of Natural History, v. 146, p. 1-66.

SCOTT, R.W. (1970) Paleoecology and paleontology of the Lower Cretaceous Kiowa Formation, Kansas. University of Kansas Paleontologic Contributions Articles, v. 52 (Cretaceous 1), p. 194.

SCHAFER, W. (1972) Ecology and paleoecology of marine environments. University of Chicago Press. 568p.

SEED, R.; SUCHANECK, T.H. (1980) Population and community ecology of Mytilus. In: LUTZ, R.A. (ed.) Mussel culture and harvest: a North American perspective. Developments in Aquaculture and fishiries science, v. 7, p. 87-169.

SEILACHER, A. (1985) The Jeram model: event condensation in a modern intertidal environment. In: FRIEDMANN, G.M. (ed.), Sedimentary and evolutionary cycles, Lecture Notes in Earth Sciences, v. 1, p. 336-342.

SEILACHER, A; REIF, W.E.; WESTPHAL, F. (1985) Sedimentological, ecological and temporal patterns of fossil Lagerstätten. Philosophical Transactions of the Royal Society of London, v. B311, p. 5-23.

\section{SHIGINAKA, G. (1997) Integrating} physical and biological studies of recovery from the Exxon Valdez oil spill. NOAA Technical Memorandum NOS ORCA 114.

SIMŐES, M.G. (1988) Técnicas de preparação de bivalves silicificados com vistas ao estudo da morfologia interna. In: CONGRESSO BRASILEIRO DE ZOOLOGIA, 15. Curitiba, 1988, Resumos. Curitiba, $p$. 49.

SIMŐES, M.G. (1992) Pelecípodes da Formaçăo Palermo (Permiano) de Săo Sepé (RS) e Guiratinga (MT): implicações na evolução da fauna neopaleozóica da Bacia do Paraná, Brasil. Universidade de São Paulo, São Paulo(Tese-Doutorado) Instituto de Geociências, Universidade de São Paulo, 286p.

SIMOEES, M.G. (1996a) Pelecypod taphofacies of Corumbatai Formation (Late Permian), in central Såo Paulo State, Paraná Basin, Brazil. In: $39^{\circ}$ CONGRESSO BRASILEIRO DE GEOLOGIA, Salvador, 1996, Anais... p. 298-300.

SIMŐES, M.G. (1996b) Tafonomia: estado da arte e perspectivas futuras. Noticiário do Núcleo de Sáo Paulo. Paraná da SBP, n. 17,p. 3-12.

SIMŐES, M.G. (1998) Tafonomia, timeaveraging e resolução espacial de concentraçóes fossiliferas internamente complexas: um estudo de casos do Permiano, Bacia do Paraná - Brasil e suas implicaçðes paleoecológicas. Botucatu, 160p. (Tese-Livre - 
Docência) - Instituto de Biociências, Universidade Estadual

Paulista/UNESP.

SIMŐES, M.G.; ANELLI, L.E. (1995)

Runnegariella, um novo gênero de megadesmideo

(Mollusca,

Pelecypoda) do Grupo Passa Dois

(Permiano), Bacia do Paraná, Brasil.

Geociências, v. 14, n. 2, p. 191-173.

SIMOES, M.G.; FITTIPALDI, F.C. (1987)

Bivalves do Grupo Passa Dois,

Permiano da Bacia do Paraná:

sinopse das pesquisas. In: $6^{\circ}$

SIMPOSIO REGIONAL DE

GEOLOGIA, Rio Claro, 1987, Atas...

v. 1, p. 281-295.

SIMŐES, M.G.; FITTIPALDI, F.C. (1988)

As conchas fosseis da regiăo de

Rio Claro, SP. Arquivo do municipio,

Rio Claro, 75p.

SIMŐES, M.G.; FITTIPALDI, F.C. (1992)

Fósseis da Regiăo de Rio Claro,

SP. Arquivo do Município, Rio Claro, $77 p$.

SIMÕES, M.G.; KOWALEWSKI, M. (1998a) Shell beds as paleoecological puzzles: a case study from the Upper Permian of the

Paraná Basin, Brazil. Facies, v. 38 ,

p. 175-196.

SIMŐES, M.G.; KOWALEWSKI, M. (1998b) Genetic complexity and geobiological implications of "simple" shell beds: an example from the Upper Permian of Paraná Basin, Brazil. Joumal of African Earth Sciences, v. 27, n. 1A, p. 179-180.
SIMÓES, M.G.; ROCHA-CAMPOS, A.C. (1992) Pelecípodes neopaleozóicos da Bacia do Paraná, Brasil: perspectiva bioestratigráfica. In: CONGRESSO BRASILEIRO DE GEOLOGIA, 15., São Paulo, 1992. Boletim de Resumos Expandidos. São Paulo, p. 500-502.

SIMÓES, M.G.; ROCHA-CAMPOS, A.C. (1993) Systematics and paleoecology of the pelecypods of the Palermo Formation (Permian), Paraná Basin, Brazil. Anais da Academia brasileira de Ciéncias, $v$. 65, n. 3, p. 324.

SIMÓES, M.G.; ROHN, R. (1996) On the significance of phosphatic concentration at Serra Alta Formation (Passa Dois Group, Late Permian), Paraná Basin, Brazil. In: CONGRESSO BRASILEIRO DE GEOLOGIA, 39., Salvador, 1996. Anais. Salvador, p. 295-297.

SIMÓES, M.G.; TORELLO, F.F. (em preparação) Modelo de tafofacies para o Grupo Passa Dois (formaçőes Serra Alta, Terezina e Corumbatai).

SIMOES, M.G.; TORELLO, F.F.; ROCHACAMPOS, A.C. (1994) Proximal storm shell beds or coquinas in the Corumbatai Formation (Pinzonella illusa assemblage; Late Permian), in Rio Claro, SP, Paraná Basin, Brazil. In: $38^{\circ}$ CONGRESSO BRASILEIRO DE GEOLOGIA, 38., Balneário Camboriú, 1994. Boletim de Resumos Expandidos, p. 226-227. 
SIMÖES, M.G.; TORELLO, F.F.; ROCHACAMPOS, A.C. (1996a) Gênese e classificação da coquina de Camaquã (assembléia de Pinzonella neotropica), Formação Corumbataí (Permiano Superior), Rio Claro, SP. Anais da Academia Brasileira de Ciências, v. 68 , n. 4, p. 545-557.

SIMŐES, M.G. TORELLO, F.F.; MELLO, L.H.C.; PASSOS, J.R.S.; GHILARDI, R.P. (1996b) Aplicação de tafogramas ternários no estudo das assinaturas tafonómicas de concentrações fossiliferas da Formação Corumbataí (Permiano), Bacia do Paraná, Brasil. In: CONGRESSO BRASILEIRO DE GEOLOGIA, 39., Salvador, 1996. Anais. Salvador, p. 301.

SIMOES, M.G; TORELLO, F.F.; KOWALEWSKI, M; KLEIN, C.; MELLO, L.H.C.; GHILARDI, R.P. (1998a) Are the Obrution Deposits the most precise and best resolved beds in event stratigraphy? Some Paleozoic examples from the Paraná Basin, Brazil. In: CONGRESSO BRASILEIRO DE GEOLOGIA, 40., Belo Horizonte; 1998. Anais. Belo Horizonte, SBG, p. 444.

SIMŐES, M.G.; KOWALESKI, M.; TORELLO, F.F.; ANELLI, L.E. (1998b) Long-term time-averaging despite abrupt burial: Paleozoic obrution deposits from epeiric settings of Parana Basin, Brazil. The Geological Society of America
Annual Meeting, Abstracts with Program, Toronto, p. A-384.

SIMŐES, M.G.; ROCHA-CAMPOS, A.C.; ANELLI, L.E. (1998c) Paleoecology and evolution of Permian pelecypod assemblages (Paraná Basin) from Brazi. in: JOHNSTON, P.A.; HAGGART, J.W. (eds.) Calgary, University of Calgary Press, p. 443452.

SIMÓES, M.G.; TORELLO, F.F.; MELLO, L.H.C.; GHILARDI, R.P. (em preparação) Novos afloramentos fossiliferos do Grupo Passa Dois (Permiano Superior), nas porçőes centro sul e nordeste do Estado de Săo Paulo: implicaçōes paleoecológicas e bioestratigráficas. Anais da Academia Brasileira de Ciéncias.

SIMŐES, M.G.; KOWALEWSKI, M.; TORELLO, F.F.; KLEIN, C. (submetido) High resolution taphonomy of the Paleozoic obrution deposits from epeiric settings of Paraná Basin, Brazil: the paleobiological consequences and paleoecological implications of abrupt burial. Geology.

SOARES, P.C.; SINELLI, O.; PENALVA, F.; WERNICK E.; SOUZA, A.; CASTRO, P.R.M. (1973) Geologia do Nordeste do Estado de São Paulo. In: CONGRESSO BRASILEIRO DE GEOLOGIA, 27. Aracaju, 1973. Anais. Aracaju, SBG, p. 209-228. 
SOKAL, R.R.; ROHLF, F.J. (1995)

Biometry. W.H. Freemann, 887p.

SOIJSA, S.H.M. (1985) Fácies

sedimentares das Formaçōes

Estrada Nova e Corumbatai no

Estado de São Paulo. São Paulo,

142p. (Dissertaçăo-Mestrado) -

Instituto de Geociências

Universidade de São Paulo.

SPEYER, S.E. (1985) Enroliment strategies

in Middle Devonian trilobites.

Geological Society of America,

Abstract with Programs, v. 17, p.

724.

SPEYER, S.E. (1987) Comparative taphonomy and palaeoecology of trilobite Lagerstätten. Alcheringa, $v$. 11, n. 2, p. 205-232.

SPEYER, S.E. (1988) Biostratinomy and functional morfology of enroliment in two Middle Devonian trilobites. Lethaia, v. 21, n. 1, p. 121-138.

SPEYER, S.E. (1990) Enrollament in trilobites. In: BOUCOT, A.J. (ed.) Evolutionary Paleobiology of behavior an coevolution, Elsevier, p. $450-455$.

SPEYER, S.E. (1991) Trilobite taphonomy: a basis for comparative studies of artropod preservation, functional anatomy and behavior. In: DONAVAN, S.K. The process of fossilization. New York, Columbia Univiversity Press, p. 194-219.

SPEYER, S.E.; BRETT, C.E. (1986) Trilobite taphonomy and Middle
Devonian taphofacies. Palaios, v. 1 , p. 312-327.

SPEYER, S.E.; BRETT, C.E. (1988) Taphofacies models for epeiric sea environments: Middle Paleozoic examples. Palaeogeography,

Palaeoclimatology,

Palaeoecology, v. 63, p. 22-262.

SPEYER, S.E.; BRETT, C.E. (1991)

Taphonomic controls: background and episodics processes in fossil assemblage preservation. In: ALLISON, P.A.; BRIGGS, D.E.G. (eds.) Taphonomy: realeasing the data locked in the fossil record. Plenum Press, p. 501-545.

STANLEY, S.M. (1970) Relation of shell form to life habits of the Bivalvia (Mollusca). Geological Society of America Memoir, v. 125, p. 1-296.

STANLEY, S.M. (1972) Functional morphology and evolution of the Bivalvia (Mollusca). Journal of Paleontology, v. 46, p. 165-212.

TORELLO, M.G.; SIMÓES, M.G. (1993a) Características tafonómicas da assembléia de Pinzonella illusa Reed, Formaçăo Corumbatal (Neopermiano), Bacia do Paraná, Brasil. In: CONGRESSO BRASILEIRO DE PALEONTOLOGIA, $13^{\circ}, \quad$ São Leopoldo, 1993. Boletim de Resumos. São Leopoldo, SBP, p.68. TORELLO, F.F.; SIMOES, M.G. (1993b) O significado paleoambiental de pelecípodes fósseis preservados 
com as valvas articuladas abertas ("butterflied"). In: CONGRESSO DE INICIAÇÃO CIENTIFICA DA UNESP, 5., BAURU, 1993. Caderno de Resumos. Bauru, p. 80.

TORELLO, F.F.: SIMÓES, M.G. (1994)

Características tafonômicas da assembléia de Pinzonella illusa Reed, Formação Corumbataí (Neopermiano), Bacia do Paraná, Brasil. Acta Geologica Leopoldensia, v. $39 / 1$, n. 17, p. 159173.

TORELLO, F.F.; SIMŐES, M.G. (1996) Concentraçőes fossiliferas da Formação Corumbataí (Permiano), Bacia do Paraná, na região de Tambaú, SP. Academia Braslleira de Ciências, Sessăo Regular, Ciencias da Terra, Programas $e$ Resumos, p.20.

TORELLO, F.F.; SIMÓES, M.G.; MELLO, L.H.C. (1997) On addition to the paleobiogeographic knowledge of the Passa Dois Group (Late Permian) pelecypods, Paraná Basin, Brazil. In: CONGRESSO BRASILEIRO DE PALEONTOLOGIA, 15., São Pedro, 1997. Boletim de Resumos. São Pedro. SBP, p. 71.

WALKER, R.G. (1984) Shelf and shallow marine sands. In: WALKER, R.G. (ed.), Facies Models, Geoscience Canada ReprintSeries, $2^{\text {nd }}$ Edition, $p$. 141-169.

WALKER, K.R.; BAMBACH, R.K. (1971) The significance of fossil assemblages from fine-grained

sediments: time everaged communities. Geological Society of America Abstracts with Programs, v. 3, p. 783-784.

ZAR, J.H. (1996) Biostatistical Analysis.

Prentice Hall, 661p. 